\title{
Review-Quantification of Hydrogen Peroxide by Electrochemical Methods and Electron Spin Resonance Spectroscopy
}

\author{
Rubin Gulaboski, ${ }^{1,=}$ Valentin Mirčeski, ${ }^{2,}=$ Reinhard Kappl, ${ }^{3}$ Markus Hoth, ${ }^{3}$ \\ and Monika Bozem $\oplus^{3, z}$ \\ ${ }^{1}$ University “Goce Delčev”-Štip, Faculty of Medical Sciences, Štip, Republic of North Macedonia \\ ${ }^{2}$ Institute of Chemistry, Faculty of Natural Sciences and Mathematics, "Ss Cyril and Methodius" University, \\ 1000 Skopje, Republic of North Macedonia \\ ${ }^{3}$ Department of Biophysics, Center for Integrative Physiology and Molecular Medicine, Faculty of Medicine, Saarland \\ University, 66421 Homburg, Germany
}

\begin{abstract}
Reactive oxygen species (ROS) exhibit different spatial and temporal distributions as well as concentrations in- and outside the cell, thereby functioning as signaling or pathogen-destroying molecules. Especially the $\mathrm{ROS}_{2} \mathrm{O}_{2}$ is important for the patho/physiological status of an organism. Electrochemistry (EM) and electron spin resonance (ESR)-based techniques allow quantification of $\mathrm{H}_{2} \mathrm{O}_{2}$ in artificial and living systems, coping a concentration range from low $\mathrm{nM}$ up to $\mathrm{mM}$. Working electrodes for EM are optimized by diverse modifications and, additionally, redox mediators are used. Ultramicroelectrodes allow scanning of single cells to spatially resolve and quantify extracellular $\mathrm{H}_{2} \mathrm{O}_{2}$ in real-time. With ESR spectroscopy, ${ }^{\circ} \mathrm{O}_{2}{ }^{-}$, but not $\mathrm{H}_{2} \mathrm{O}_{2}$, can be directly determined by spin probes in- and outside of cells in suspensions. Monitoring $\mathrm{H}_{2} \mathrm{O}_{2}$ requires formation of intermediate radicals, detectable with spin probes. Low $\mu \mathrm{M}\left[\mathrm{H}_{2} \mathrm{O}_{2}\right]$ can thus be assessed specifically. Using suitable spin traps, in-vivo ESR and immuno-spin trapping can visualize different radicals at their respective production sites in small animals, organs and tissues. Here, the redox reaction cascades may interfere with cell metabolism. Optimization of all methods established for $\mathrm{H}_{2} \mathrm{O}_{2}$ determination would be favorable to finally combine them for mutual validation. Thus, a deeper insight into cellular ROS metabolism can be obtained.

(C) The Author(s) 2019. Published by ECS. This is an open access article distributed under the terms of the Creative Commons Attribution Non-Commercial No Derivatives 4.0 License (CC BY-NC-ND, http://creativecommons.org/licenses/by-nc-nd/4.0/), which permits non-commercial reuse, distribution, and reproduction in any medium, provided the original work is not changed in any way and is properly cited. For permission for commercial reuse, please email: oa@electrochem.org. [DOI: 10.1149/2.1061908jes]
\end{abstract}

(c)) BY-NC-ND

Manuscript submitted March 13, 2019; revised manuscript received April 24, 2019. Published May 23, 2019.

\section{Redox Chemistry of Hydrogen Peroxide}

Hydrogen Peroxide $\left(\mathrm{H}_{2} \mathrm{O}_{2}\right)$ is widely recognized as one of the most important small molecules responsible for physiological functioning of cells in prokaryotes as well as eukaryotes. ${ }^{1} \mathrm{H}_{2} \mathrm{O}_{2}$ can be produced intra- and extracellularly. Both, $\mathrm{H}_{2} \mathrm{O}_{2}$ and its precursor superoxide $\left({ }^{\cdot} \mathrm{O}_{2}^{-}\right)$belong to the reactive oxygen species (ROS). Together with reactive nitrogen species (RNS), calcium ions and others, these are universal signaling species in cells. ${ }^{2-12}$ In principle, $\mathrm{H}_{2} \mathrm{O}_{2}$ is formed by a sequential $2 \mathrm{e}^{-}$transfer to $\mathrm{O}_{2}$, whereby the intermediate radical ${ }^{\circ} \mathrm{O}_{2}{ }^{-}$is produced. ${ }^{\prime} \mathrm{O}_{2}{ }^{-}$is subsequently protonated resulting in the nonradical $\mathrm{H}_{2} \mathrm{O}_{2}$. The oxygen reduction cascade shown in Figure $1 \mathrm{de}-$ picts reactions leading to various radical or non-radical ROS in vitro. In cellular systems, oxygen reduction under physiological conditions is controlled by special enzymes which contribute to a balanced ROS level inside and outside the cell. ${ }^{13}$ Cellular ${ }^{\circ} \mathrm{O}_{2}{ }^{-}$is produced by intracellular or cell membrane-residing enzyme complexes (NADPH oxidases, $\mathrm{NOX}$ ), which reduce $\mathrm{O}_{2}$ by a $1 \mathrm{e}^{-}$transfer. Additionally, ${ }^{\circ} \mathrm{O}_{2}{ }^{-}$ can be a product of pathways localized in mitochondria, ${ }^{14-21}$ in other organelles or the cytoplasm. ${ }^{22} \cdot \mathrm{O}_{2}{ }^{-}$is rapidly dismutated to $\mathrm{H}_{2} \mathrm{O}_{2}$ and $\mathrm{O}_{2}$. This can occur spontaneously (lifetime is about $10^{-4} \mathrm{~s}$ ) or is catalyzed by intra- and extracellular superoxide dismutases (SOD), which accelerate dismutation by a factor of $10^{4} \cdot{ }^{23-25} \cdot \mathrm{O}_{2}{ }^{-}$is highly reactive, and cells aim to keep its steady-state concentration low.

The more stable $\mathrm{H}_{2} \mathrm{O}_{2}$ not only serves as a signaling molecule in cells, ${ }^{11,22,26-34}$ but is also used by phagocytes to destroy infectious invaders. ${ }^{35,36}$ White blood cells of various types, such as monocytes, macrophages, neutrophils, dendritic and mast cells function as phagocytotic cells engulfing pathogens and destroying them. Involvement of $\mathrm{H}_{2} \mathrm{O}_{2}$ in physiological metabolism as well as in stress responses related to ageing and a variety of pathological conditions is also well confirmed. ${ }^{29,37-41}$

In numerous intracellular reactions with ROS, thiol-containing molecules are targeted, which undergo redox transformation, ${ }^{42,43}$ thus leading to mostly transient and reversible activation or inhibition of various signaling processes. ${ }^{26,27,33,44-47}$ In a recent review, Rhee et al.

\footnotetext{
$=$ These authors contributed equally to this work.

zE-mail: monika.bozem@uks.eu
}

presented the pivotal role of peroxiredoxins as intracellular transducers for $\mathrm{H}_{2} \mathrm{O}_{2}$ signals. ${ }^{48}$ The $\mathrm{H}_{2} \mathrm{O}_{2}$-induced oxidation of thiols or other targets, like lipids and nucleic acids, and the pathways to reduce them again, are far from being simple reversible reactions. ${ }^{49,50}$ To understand $\mathrm{H}_{2} \mathrm{O}_{2}$ function in cells, a deeper insight into its redox chemistry is required. $\mathrm{H}_{2} \mathrm{O}_{2}$ can gain or lose electrons in different reaction types. Environmental parameters, for instance $\mathrm{pH}$, determine whether $\mathrm{H}_{2} \mathrm{O}_{2}$ reacts as an oxidant or as a reductant ${ }^{51,52}$ The two-electron reduction and oxidation of $\mathrm{H}_{2} \mathrm{O}_{2}$ at $\mathrm{pH}$ of 7 are described by the following Reactions 1 and 2, respectively:

$$
\mathrm{H}_{2} \mathrm{O}_{2}+2 \mathrm{H}^{+}+2 \mathrm{e}^{-} \rightarrow 2 \mathrm{H}_{2} \mathrm{O} \quad \mathrm{E}^{\theta}=+1.534 \mathrm{~V} \text { versus SCE }
$$

$$
\mathrm{H}_{2} \mathrm{O}_{2} \rightarrow 2 \mathrm{H}^{+}+\mathrm{O}_{2}+2 \mathrm{e}^{-} \quad \mathrm{E}^{\theta}=+0.440 \mathrm{~V} \text { versus } \mathrm{SCE}
$$

(SCE stands for saturated calomel reference electrode; NHE is normal hydrogen electrode / see next paragraph).

In the first half-Reaction $1, \mathrm{H}_{2} \mathrm{O}_{2}$ is reduced to $\mathrm{H}_{2} \mathrm{O}$ while it acts as an oxidant; in the second Reaction $2, \mathrm{H}_{2} \mathrm{O}_{2}$ functions as a reductant. Since the standard redox potential of the couple $\mathrm{H}_{2} \mathrm{O}_{2} / \mathrm{H}_{2} \mathrm{O}$ in neutral medium is rather high $(+1.534 \mathrm{~V}$ versus SCE, or $+1.76 \mathrm{~V}$ versus NHE), this would imply a high oxidative force for $\mathrm{H}_{2} \mathrm{O}_{2}$. However, redox systems with $\mathrm{H}_{2} \mathrm{O}_{2}$ at neutral $\mathrm{pH}$ are mainly kinetically but not thermodynamically driven. Due to the slow kinetics of its redox reactions, $\mathrm{H}_{2} \mathrm{O}_{2}$ acts as a moderate oxidant under physiological conditions. ${ }^{26,53}$ This may explain the low reactivity of redox-active biological molecules with $\mathrm{H}_{2} \mathrm{O}_{2}$. On the other hand, the $\mathrm{O}-\mathrm{O}$ bond of $\mathrm{H}_{2} \mathrm{O}_{2}$ (H-O-O-H) is quite sensitive to UV light, heating $(T)$, ionizing radiation $(X)$ and metal ions, like $\mathrm{Fe}^{2+}$ and $\mathrm{Cu}^{2+},{ }^{54,55}$ the breakdown of the $\mathrm{O}-\mathrm{O}$ bond produces the hydroxyl radical $\mathrm{HO}^{*}$ during homolytic bond cleavage or catalytic reactions (see Figure 1). The hydroxyl radical with a lifetime in the range of $10^{-9} \mathrm{~s}$ is the most reactive ROS known and is responsible for the "oxidative damage" of cells, reacting indiscriminately with many organic molecules and abolishing their functions. ${ }^{35,56-59}$ Thus, determination and precise quantification of ROS, like ${ }^{\circ} \mathrm{O}_{2}{ }^{-}$and $\mathrm{H}_{2} \mathrm{O}_{2}$, in living systems under physiological and pathological conditions are of exceptional importance for understanding cell metabolism controlled by redox reactions. This would 


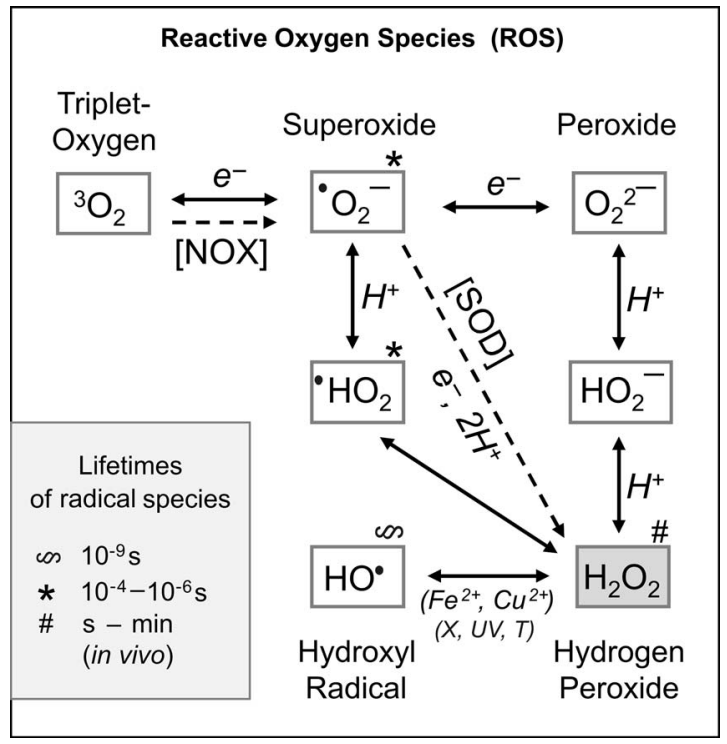

Figure 1. Reduction processes of oxygen $\left(\mathrm{O}_{2}\right)$ forming reactive oxygen species (ROS). The cascade is initiated by electron transfer steps (top row) followed by protonation of the intermediate molecules (middle row). Within the cascade, different short-lived highly reactive radicals (marked with a black dot) exist. ${ }^{\bullet} \mathrm{O}_{2}{ }^{-}$and ${ }^{\bullet} \mathrm{HO}_{2}$ are dismutated spontaneously to $\mathrm{H}_{2} \mathrm{O}_{2}$ and $\mathrm{O}_{2}$. The hydroxyl radical $\left(\mathrm{HO}^{\bullet}\right)$ is regarded to be the most hazardous species in living systems. In the presence of $\mathrm{Fe}^{2+}$ or $\mathrm{Cu}^{2+}$ ions, $\mathrm{HO}^{\bullet}$ is produced by reduction of $\mathrm{H}_{2} \mathrm{O}_{2}$ and concomitant oxidation of the metal ions (lower row). This radical can also be formed by radiation ( $X, U V$ light) or high temperature $(T)$. Approximate lifetimes of selected species are listed in the inset. In cellular systems, the enzymes NADPH oxidases (NOX) and superoxide dismutases (SOD) cause directed and irreversible production of superoxide $\left({ }^{\bullet} \mathrm{O}_{2}{ }^{-}\right)$and $\mathrm{H}_{2} \mathrm{O}_{2}$, respectively. These enzymes are highly regulated and contribute to the balancing of ROS under physiological conditions. In vivo, radicals are effectively transformed into non-radicals by enzymatic and non-enzymatic reactions.

probably also help improving diagnosis and therapeutic attempts to cure diseases being linked to defective ROS balance in patients. ${ }^{60-64}$

Diverse approaches to measure ROS in organisms, tissues and cells have been developed in the last decades. Some of these methods are based on enzymatic, fluorescent and luminescent techniques. ${ }^{65-71}$ More recent approaches use genetically-encoded protein sensors or transgenic organisms to determine $\mathrm{H}_{2} \mathrm{O}_{2} .{ }^{72-79}$ While these approaches all have advantages and disadvantages, ${ }^{65,71,80-84}$ one of their major problems is the quantification of absolute $\left[\mathrm{H}_{2} \mathrm{O}_{2}\right]$ or even cellular $\left[\mathrm{H}_{2} \mathrm{O}_{2}\right]$ kinetics. Another serious issue is the fact that measurements with fluorescent proteins may cause phototoxicity leading to oxidative stress in cells. Furthermore, some genetically-encoded fluorescent proteins directly generate ${ }^{\circ} \mathrm{O}_{2}{ }^{-}$after excitation. ${ }^{85-91}$

The main focus of our review article is on electrochemical and electron spin resonance (ESR) spectroscopic methods for determination of $\mathrm{H}_{2} \mathrm{O}_{2}$. Both allow precise $\left[\mathrm{H}_{2} \mathrm{O}_{2}\right]$ quantification also in a cellular context. Since very important for cell biology, the ancillary issues of ${ }^{\circ} \mathrm{O}_{2}{ }^{-}$and $\mathrm{HO}^{\cdot}$ measurements are also briefly addressed. The electrochemical and ESR-based methods not only turned out complementary to those mentioned in the foregoing paragraph, they even should be favored under certain conditions. In the following, we present and critically discuss the most relevant electrochemical and ESR methods developed so far to measure and potentially quantify $\mathrm{H}_{2} \mathrm{O}_{2}$ (and ${ }^{\circ} \mathrm{O}_{2}{ }^{-}$, $\mathrm{HO}^{*}$ ) in various systems, including those of living cells. We have tried to deduce the most important findings from the multitude of published articles and references knowing that the list of citations remains incomplete. For a better overview the table in Conclusive evaluations of electrochemical and ESR spectroscopic $\mathrm{H}_{2} \mathrm{O}_{2}$ (and ${ }^{\circ} \mathrm{O}_{2}^{-}$) determinations section summarizes the main electrochemical sensors and ESR methods, their applications and limitations (see Table I).

\section{Electrochemical Determination and Quantification of $\mathrm{H}_{2} \mathrm{O}_{2}$}

Within the last $\sim 30$ years, numerous electrochemical techniques, such as voltammetry, chronoamperometry, potentiometry, coulometry and electrochemical impedance spectroscopy have been used as efficient tools to determine $\mathrm{H}_{2} \mathrm{O}_{2}$ in various in-vitro and in-vivo systems. Excellent overviews are given by review articles published within the last decade. ${ }^{92-101}$ In spite of numerous efforts to develop electrochemical sensors for quantitative determination of $\mathrm{H}_{2} \mathrm{O}_{2}$ in in-vitro systems, easy handling and applicability, high sensitivity, selectivity and reproducibility as well as a fast response time of a sensor still remain to be challenging goals. ${ }^{94,102}$ Applying technically optimized electrochemical methods in living systems are even more ambitious; they often fail because of toxic materials used for electrode construction and/or performance.

Voltammetry and chronoamperometry.-Starting with voltammetric methods, which provide qualitative, quantitative and mechanistic insight into the redox reaction studied, ${ }^{103,104}$ we focus on recent methodological developments for quantification of $\mathrm{H}_{2} \mathrm{O}_{2}$. Voltammetric devices are electrochemical sensors which continuously measure the faradaic current resulting from oxidation/reduction reactions occurring at a working electrode (WE) surface of a given electroactive species. The species is dissolved in an electrolyte solution or is immobilized on the WE tip surface. Redox reactions are driven by the potential difference at the electrode/electrolyte interface, which is measured and controlled versus a reference electrode (RE). One of the main voltammetric techniques for mechanistic study of redox transformations of $\mathrm{H}_{2} \mathrm{O}_{2}$ and its quantitative determination is cyclic voltammetry $(\mathrm{CV}) . \mathrm{CV}$ is an electroanalytical technique, in which the electrode interfacial potential is varied in a cyclic mode, thus enabling the redox equilibrium of a given redox couple to be repeatedly inspected in both, reductive and oxidative directions. ${ }^{104-106}$

Besides conventional $\mathrm{CV}$, a variant called fast scan cyclic voltammetry emerged as a powerful tool for detection of biomolecules including $\mathrm{H}_{2} \mathrm{O}_{2} .{ }^{107-113}$ Other, more advanced pulse voltammetric techniques, such as normal (NPV) and differential pulse voltammetry [DPV; $;^{114,115}$ ] as well as square-wave voltammetry [SWV; ${ }^{103,116-121}$ ] are also applied to determine $\mathrm{H}_{2} \mathrm{O}_{2}$ with very high sensitivity. The latter enables low detection limits within the nanomolar range for $\mathrm{H}_{2} \mathrm{O}_{2}$ determination, thus being superior over other voltammetric techniques. In a recently published article we confirmed the superiority of SWV reporting a very low limit for $\mathrm{H}_{2} \mathrm{O}_{2}$ of $5 \mathrm{nM}$, using a bare Ptultramicroelectrode. ${ }^{122}$ Applying DPV, detection limits for $\mathrm{H}_{2} \mathrm{O}_{2}$ were in the same range (Bozem; unpublished results). Chronoamperometry, conducted at a specific constant potential can be applied to monitor $\mathrm{H}_{2} \mathrm{O}_{2}$ with higher temporal resolution (such as $1 \mathrm{kHz}$ ) than voltammetric methods do. It turned out to be the most appropriate electrochemical technique to follow kinetics of (electro) chemical reactions in the test solution.

First-generation electrochemical $\mathrm{H}_{2} \mathrm{O}_{2}$ sensors.-From a thermodynamic point of view, $\mathrm{H}_{2} \mathrm{O}_{2}$ is expected to be reduced or oxidized at a variety of electrode materials. However, slow kinetics of the electron transfer at most electrodes (or nanostructures functioning as electrodes) leads to very high over-potentials of $\mathrm{H}_{2} \mathrm{O}_{2}$ electrode transformation. ${ }^{99,123-126}$ The overpotential is defined as the difference in voltage between the redox potentials determined for a halfreaction under ideal thermodynamic compared to real experimental conditions. Some noble metals, like Au, Ag, Pt, ${ }^{123,127}$ ignoble metals or metal oxides, like $\mathrm{Cu}$ or $\mathrm{CuO},{ }^{128}$ or non-metal catalysts, e.g., carbon-type electrodes ${ }^{129-131}$ could help to accelerate redox transformations. For instance, reduction of $\mathrm{H}_{2} \mathrm{O}_{2}$ at bare electrodes, as schematically depicted in Figures $2 \mathrm{~A}$ and $2 \mathrm{~B}$ is associated with a single irreversible voltammetric peak at negative potential, which is ascribed to the overall Reaction 1, specified in Redox chemistry of hydrogen peroxide section. The electrode mechanism is mainly affected by the kinetics of interfacial electron transfer and the rate of diffusional mass transport. In some cases, reduction of $\mathrm{H}_{2} \mathrm{O}_{2}$ at bare 
Table I. Electrochemical and ESR spectroscopic $\mathrm{H}_{2} \mathrm{O}_{2}\left(\right.$ and $\left.^{\circ} \mathrm{O}_{2}{ }^{-}\right)$determination techniques.

ELECTROCHEMICAL TECHNIQUES

\begin{tabular}{|c|c|}
\hline Sensor Type & Composition \\
\hline $\begin{array}{l}\text { ELECTRODE } \\
\text { (macro, mini) } \\
\text { "1st generation" } \\
\text { (Fig. 2) }\end{array}$ & $\begin{array}{c}\text { bare metal }(\mathrm{Au}, \mathrm{Ag}, \mathrm{Pt}) \text { or carbon } \\
\text { fiber fused in a glass capillary; } \\
\text { tip can be platinized (covered } \\
\text { with particles) }\end{array}$ \\
\hline \multirow[t]{3}{*}{$\begin{array}{l}\text { ELECTRODE } \\
\text { (macro, mini) } \\
\text { "2 } 2^{\text {nd }} \text { generation" } \\
\text { (Fig. 3) }\end{array}$} & $\begin{array}{l}\text { metal or carbon, modified with } \\
\text { electro-conductive and } \\
\text { electro-catalytic materials (e.g., } \\
\text { Au, Ag, Pt, thiols, amino acids } \\
\text { and others) }\end{array}$ \\
\hline & $\begin{array}{l}\text { metal or carbon, modified with } \\
\text { metal or carbon nano-particles; } \\
\text { nanotubes with bound inorganic } \\
\text { or organic materials; also } \\
\text { material combinations } \\
\text { ("bi-metallic"); stabilization by } \\
\text { thiols }\end{array}$ \\
\hline & $\begin{array}{l}\text { metal or carbon with immobilized } \\
\text { redox mediators, e.g., metal } \\
\text { complexes at the electrode tip or } \\
\text { redox mediators dissolved in } \\
\text { solution }\end{array}$ \\
\hline
\end{tabular}

\section{ELECTRODE; MEA; \\ hybrid-film ES "graphene"}

ELECTRODE

(macro, mini)

" $3^{\text {rd }}$ generation"

(Fig. 4)

dual- and multimode ES

metal or carbon, "charged" nanoparticles attached, to which selected proteins/enzymes are bound; metalloproteins $\left(\mathrm{Fe}^{2+} / \mathrm{Fe}^{3+}\right)$

metal or carbon, "charged" nanoparticles and (metallo) proteins/enzymes plus redox mediators in solution

carbon- or graphite-based ink; $\mathrm{Ti}_{3} \mathrm{C}_{2}$-graphene oxide; modified with Prussian Blue nanoparticles, gold or osmium-wired HRP

carbon or metal; graphene (or -oxide) attached as monolayers, SWNTs or MWNTs; optionally with $\mathrm{H}_{2} \mathrm{O}_{2}$-binding proteins, metal particles or other materials

graphene- or carbon-nanotube based; Co-oxide modified glassy carbon electrode; carbon nano-particle composite film; nano-porous Co-Pt alloy

\section{MICRO- and \\ ULTRA- \\ MICRO- \\ (UME)}

ELECTRODE

MICRO-

ELECTRODE; MEA; E-CHIP

, metal or "hybrid" metal which ${ }^{\circ} \mathrm{O}_{2}{ }^{-}$-binding proteins can be mounted

(bi-)metallic, modified with different (nano) materials and enzymes

\begin{tabular}{ccc} 
Specificity & Sensitivity $($ LOD $)$ & Application \\
\hline $\mathbf{H}_{2} \mathbf{O}_{2}$, other ROS; RNS & $\mathrm{nM}$ to low $\mathrm{mM}$ & in vitro; \\
(at specific potentials) & & extracellular \\
& & fluid of cell \\
& suspensions
\end{tabular}

$\mathrm{H}_{2} \mathrm{O}_{2}$ (specifically catalyzed by the selected materials)

$\mathrm{H}_{2} \mathrm{O}_{2}$ (specifically supported by the selected materials)

$\mathrm{nM}$ to $\mathrm{mM}$

$\mathrm{nM}$ to $\mathrm{mM}$

in vitro extracellular fluid of cell suspensions

in vitro; extracellular fluid of cell suspensions

$$
\begin{gathered}
\mathrm{H}_{2} \mathrm{O}_{2} \text { (not very } \\
\text { selective) }
\end{gathered}
$$

$\mathrm{H}_{2} \mathrm{O}_{2}$ (selective due to $\mathrm{H}_{2} \mathrm{O}_{2}$-binding proteins/enzymes)
$\mathbf{H}_{2} \mathrm{O}_{2}$ (selective; specific redox mediators)

$\mathbf{H}_{2} \mathrm{O}_{2}$ (selective due to the selected materials)

$\mathrm{H}_{2} \mathrm{O}_{2}$ (selective due to the selected materials)

$\mathrm{H}_{2} \mathrm{O}_{2}$ and glucose, or gallic acid,

cholesterol, peracetic acid, ethanol, nitrite, hydrazine, iodate,

in vitro; extracellular fluid of cell suspensions

$$
\mathrm{nM} \text { to } \mu \mathrm{M}
$$

$40 \mathrm{nM}$ to $10 \mu \mathrm{M}$

(1)

\section{$13.7 \mathrm{nM}$ to} $1.95 \mu \mathrm{M}$

$$
\cdot \mathbf{O}^{-} \quad \text { low nM to } \mu \mathrm{M}
$$
bromate

low $\mu \mathrm{M}\left[\mathrm{H}_{2} \mathrm{O}_{2}\right]$; $\mathrm{nM}$ to $\mu \mathrm{M}$ for other substances

$\mathrm{H}_{2} \mathrm{O}_{2}$ in vitro; extracellular fluid of cell suspensions, blood

in vitro; extracellular fluid; in situ-ex vivo (dog aorta)

in vitro; extracellular fluid of cell suspensions

in vitro; extracellular fluid of cell in vitro; extracellular fluid of cell suspensions

in vitro; extracellular fluid of cell suspensions

in vitro; in vivo within brain tissue; cell clusters and suspensions
Limitations

slow kinetics and "fouling" due to adsorption processes at bare electrodes; metal particles increase active area and electrochemical performance

time-consuming and complicated electrode construction; its

lifetime may be short; toxic materials may exclude usage in cell suspensions

time-consuming and complicated electrode construction; its lifetime may be short; toxic materials may exclude usage in cell suspensions

complicated electrode construction, materials may be toxic for cells; redox-active species other than $\mathrm{H}_{2} \mathrm{O}_{2}$ may lead to unspecific results

complicated and costly electrode fabrication; proteins at the electrode may degrade quickly and may interfere with cell metabolism

(same as in the box above); redox mediators may interfere with cell metabolism or are

complicated sensor fabrication (piezo-electric inkjet printing); repeatability not always given

complicated electrode fabrication, may be expensive, layers have to be renewed frequently; graphene oxide may be toxic for cells

complicated sensor fabrication; elaborated experimental settings and preparation of samples required

complicated and costly electrode fabrication, delicate handling; long-time stability not always given; electrode materials may affect cell metabolism

complicated sensor fabrication and performance; long-time stability not always given; electrode materials may affect cell metabolism 
Table I. Continued.

\section{ELECTROCHEMICAL TECHNIQUES}

\begin{tabular}{|c|c|c|c|c|c|}
\hline Sensor Type & Composition & Specificity & Sensitivity (LOD) & Application & Limitations \\
\hline $\begin{array}{c}\text { UME } \\
(\emptyset \leq 25 \mu \mathrm{m}) \\
\text { SECM }\end{array}$ & $\begin{array}{l}\text { carbon or metal (Pt, } \mathrm{Au}, \mathrm{Ag}) \\
\text { optionally platinized or } \\
\text { otherwise modified; mostly } \\
\text { disk-shaped; flat or inclined tip }\end{array}$ & $\begin{array}{c}\mathbf{H}_{2} \mathbf{O}_{2} \text {, other ROS; } \\
\text { RNS (at specific } \\
\text { potentials) }\end{array}$ & $\begin{array}{l}\text { low fM, mostly } \\
\text { low nM to mM }\end{array}$ & $\begin{array}{l}\text { in vitro; tissue } \\
\text { slices, cell } \\
\text { suspensions; } \\
\text { outside of single } \\
\text { cells; } \\
\text { mitochondria; } \\
\text { bacteria }\end{array}$ & $\begin{array}{l}\text { complicated and costly electrode } \\
\text { fabrication, delicate handling; } \\
\text { preconditioning may prevent } \\
\text { "fouling" and damage }\end{array}$ \\
\hline $\begin{array}{l}\text { NANODE } \\
(\varnothing \leq 1 \mu \mathrm{m})\end{array}$ & $\begin{array}{c}\text { metal or carbon; modified (e.g., } \\
\text { with Prussian Blue) }\end{array}$ & $\mathbf{H}_{2} \mathbf{O}_{2}$ & $\begin{array}{c}\text { low } \mu \mathrm{M} \text { to low } \\
\mathrm{mM}\end{array}$ & $\begin{array}{l}\text { in vitro; } \\
\text { intracellular } \\
\text { space of living } \\
\text { cells }\end{array}$ & $\begin{array}{c}\text { complicated electrode fabrication } \\
\text { and application; repeated } \\
\text { electrode usage rarely possible; } \\
\text { experimental manipulations of } \\
\text { cells may interfere with (ROS) } \\
\text { metabolism }\end{array}$ \\
\hline
\end{tabular}

\section{ELECTRON SPIN RESONANCE (ESR) SPECTROSCOPY}

\begin{tabular}{|c|c|c|c|c|c|}
\hline $\begin{array}{l}\text { Method and } \\
\text { Compounds }\end{array}$ & Characteristics & Specificity & Sensitivity & Application & Limitations \\
\hline $\begin{array}{l}\text { SPIN TRAPS: } \\
\text { CYCLIC } \\
\text { NITRONES } \\
\text { (Fig. } 7 \text { ) }\end{array}$ & $\begin{array}{c}\text { cyclic nitrones with different } \\
\text { specificities, spin-adduct } \\
\text { formation, sometimes with } \\
\text { spectral signature of radical }\end{array}$ & $\begin{array}{l}\mathbf{O}_{2}^{-}, \mathbf{H O}^{\bullet}, \text { and } \\
\text { mainly } \\
\text { carbon-centered } \\
\text { radicals }\end{array}$ & $\mu \mathrm{M}$ to low $\mathrm{mM}$ & $\begin{array}{l}\text { in vitro; intra- } \\
\text { and/or } \\
\text { extracellular } \\
\text { fluid }\end{array}$ & $\begin{array}{c}\text { generally low rate constants; hig } \\
\text { concentrations }(<100 \mathrm{mM}) \\
\text { needed; short lifetimes of } \\
\text { adducts, mainly in cell } \\
\text { environment }\end{array}$ \\
\hline $\begin{array}{l}\text { SPIN PROBES: } \\
\text { CYCLIC } \\
\text { HYDROXYL- } \\
\text { AMINES } \\
\text { (Fig. 8) }\end{array}$ & $\begin{array}{l}\text { redox activation, different } \\
\text { membrane permeabilities, high } \\
\text { rate constants; low } \\
\text { concentrations }(<500 \mu \mathrm{M})\end{array}$ & $\begin{array}{l}\mathbf{O}_{2}^{-}, \mathbf{H O}^{\bullet} \text {; any } \\
\text { radical or redox } \\
\text { active metal ion }\end{array}$ & low $\mu \mathrm{M}$ & $\begin{array}{l}\text { in vitro; intra- } \\
\text { and/or } \\
\text { extracellular } \\
\text { fluid; } \\
\text { mitochondria } \\
\text { suspension }\end{array}$ & $\begin{array}{l}\text { no spectral information of } \\
\text { interacting radical, complex } \\
\text { redox chemistry possible, } \\
\text { exclude artefacts }\end{array}$ \\
\hline $\begin{array}{c}\text { HRP - ASSAY } \\
(\text { Fig. } 8)\end{array}$ & $\begin{array}{c}\text { enzymatic; HRP + p-AAP + } \\
\text { CPH; HRP + CMH; } \\
\text { complements AUR assay }\end{array}$ & $\mathbf{H}_{2} \mathbf{O}_{2}$ & $\mu \mathrm{M}$ & $\begin{array}{l}\text { in vitro; cell and } \\
\text { mitochondrial } \\
\text { suspensions }\end{array}$ & $\begin{array}{l}\text { complex redox chemistry due to } \\
\text { redox-active cyclic } \\
\text { hydroxylamines; calibration } \\
\text { may be difficult }\end{array}$ \\
\hline $\begin{array}{l}\text { SPIN PROBES } \\
\text { and TRAPS }\end{array}$ & $\begin{array}{c}\text { CPH, CMH, DMPO, } \\
\text { CD-DIPPMPO, and others }\end{array}$ & $\mathrm{O}_{2}^{-}$ & $\mu \mathrm{M}$ & $\begin{array}{l}\text { cells of different } \\
\text { types in } \\
\text { suspension }\end{array}$ & $\begin{array}{c}\text { low radical concentrations and } \\
\text { interference with cellular } \\
\text { metabolites and/or buffer } \\
\text { components require controls } \\
\text { for calibration }\end{array}$ \\
\hline IN-VIVO ESR & $\begin{array}{l}\text { functional spin probes; spin traps } \\
\text { for specific reaction kinetics; } \\
\text { elaborated technical devices and } \\
\text { ESR settings }\end{array}$ & $\begin{array}{l}\text { different radical } \\
\text { species; spin trap } \\
\text { used determines } \\
\text { specificity }\end{array}$ & $\begin{array}{l}\mu \mathrm{M} \text { at radical } \\
\text { production site }\end{array}$ & $\begin{array}{l}\text { in vivo, in situ } \\
\text { cells, tissues, } \\
\text { organs, small } \\
\text { animals, human } \\
\text { subjects }\end{array}$ & $\begin{array}{l}\text { high-price equipment, } \\
\text { experienced personnel } \\
\text { required; experimental setting } \\
\text { and analysis of data difficult; } \\
\text { possible cross-reactions of spi } \\
\text { traps with cell metabolism }\end{array}$ \\
\hline $\begin{array}{l}\text { IMMUNO-SPIN } \\
\text { TRAPPING } \\
\text { (IST) }\end{array}$ & $\begin{array}{c}\text { nitrone spin trap (DMPO) forms } \\
\text { radical spin-adduct then binding } \\
\text { to a specific antibody; Western } \\
\text { blotting, ELISA, } \\
\text { fluorescence-based methods, } \\
\text { mMRI }\end{array}$ & $\begin{array}{l}\text { different radical } \\
\text { species; selective; } \\
\text { relatively high } \\
\text { spatial resolution }\end{array}$ & semi-quantitative & $\begin{array}{l}\text { cells; ex-vivo } \\
\text { tissue samples }\end{array}$ & $\begin{array}{c}\text { sophisticated, time-consuming } \\
\text { procedure; possible } \\
\text { interference with cell } \\
\text { metabolism; no absolute } \\
\text { quantification; no dynamics } \\
\text { measurable }\end{array}$ \\
\hline \multicolumn{6}{|c|}{$\begin{array}{l}\text { Abbreviations used in Table I: AUR = Amplex UltraRed; CD-DIPPMPO = 6-monodeoxy-6-mono-4-[(5diisopropoxyphosphoryl-5-methyl-1- } \\
\text { pyrroline- } N \text {-oxide)-ethylenecarbamoyl-(2,3-di- } O \text {-methyl)hexakis-(2,3,6-tri- } O \text {-methyl)]- } \beta \text {-cyclodextrin; CMH }=1 \text {-hydroxy-3-methoxycarbonyl-2,2,5,5- } \\
\text { tetramethylpyrrolidine; } \mathrm{CPH}=1 \text {-hydroxy-3-carboxyl-2,2,5,5-tetramethyl-pyrrolidine; DMPO }=5,5 \text {-dimethyl-1-pyrroline } \mathrm{N} \text {-oxide; E-CHIP = chip com- } \\
\text { posed of several (micro) electrodes; ELISA = enzyme-linked immunosorbent assay; ES = electrochemical sensor; HRP }=\text { horseradish peroxidase; } \\
\text { IST = immuno-spin trapping; lower LOD = lower limit of detection; MEA = microelectrode array; MWNT = multi-walled nanotubes; p-AAP = } \\
\text { p-acetamidophenol; RNS = reactive nitrogen species; ROS = reactive oxygen species; SECM = scanning electrochemical microscopy; SWNT = single- } \\
\text { walled nanotubes; mMRI = molecular magnetic resonance imaging; UME = ultramicroelectrode. }\end{array}$} \\
\hline
\end{tabular}



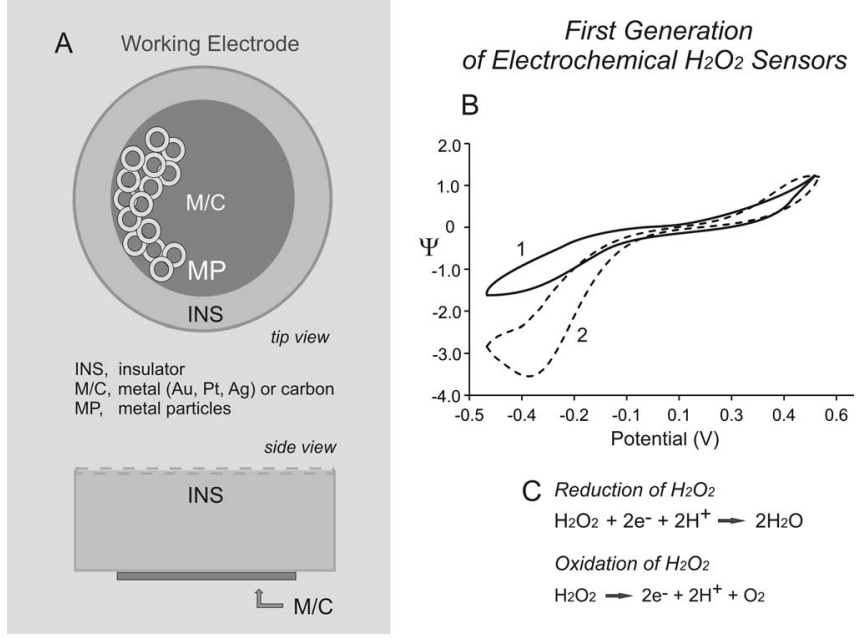

Figure 2. First-generation electrochemical $\mathrm{H}_{2} \mathrm{O}_{2}$ sensors. (A) Macroscopic (surface area in the range of square centimetre) bare metal Pt, Au, Ag or carbon/glassy carbon $(\mathrm{M} / \mathrm{C})$ working electrodes are applied versus a reference electrode to detect $\mathrm{H}_{2} \mathrm{O}_{2}$ dissolved in an electrolyte buffer with amperometric or voltammetric techniques. In order to increase the active area of the surface and thereby increase the sensitivity of the electrode, noble metal nanoparticles (MP), such as Pt, can be attached to it. (B) Assumed theoretical cyclic voltammograms in the absence (1) and presence of $\mathrm{H}_{2} \mathrm{O}_{2}(2)$ in a deoxygenated electrolyte solution. $\Psi$ stands for dimensionless current. (C) The selected potential window of cyclic voltammetry determines whether $\mathrm{H}_{2} \mathrm{O}_{2}$ is measured along anodic oxidation and/or cathodic reduction reaction(s). Electron transfer toward or from the electrode surface is reflected by (faradaic) current changes and the appearance of current peaks at the respective potential ranges.

electrodes features two reduction peaks in $\mathrm{CV} \cdot{ }^{132,133}$ The second peak might be attributed to the $\mathrm{H}_{2} \mathrm{O}_{2}$ adsorption at the surface of the working electrode. ${ }^{127,132,134}$

Detection limits of voltammetric methods referring to $\mathrm{H}_{2} \mathrm{O}_{2}$, using bare WEs, vary strongly depending mainly on the electrode material and tip size (for micro- and ultramicroelectrodes) as well as the voltammetric technique applied. Platinum WEs, for example, offer $\mathrm{H}_{2} \mathrm{O}_{2}$ determination with a high sensitivity, since Pt is a specific catalyst for $\mathrm{H}_{2} \mathrm{O}_{2}$ redox reactions. Moreover, preconditioning of the WE, e.g., electrochemical cleaning by constant potential polarization, may also contribute to the overall analytical performance of the method. Taken together, detection limits for $\mathrm{H}_{2} \mathrm{O}_{2}$ obtained with bare electrodes range from millimolar down to low nanomolar concentration levels. ${ }^{123,129,135}$

Quantification of $\mathrm{H}_{2} \mathrm{O}_{2}$.-The most common and simple way for electrochemical quantification of $\mathrm{H}_{2} \mathrm{O}_{2}$ is calibrating the measured current with the respective known concentration of $\mathrm{H}_{2} \mathrm{O}_{2}$ added to the measuring solution. Using chronoamperometry, conducted at a given constant potential, the current-concentration relationship can be easily determined and presented as a calibration curve. In voltammetric experiments, covering a broader potential window, the increasing $\left[\mathrm{H}_{2} \mathrm{O}_{2}\right]$ causes changes in the intensity of the cathodic and/or anodic current at particular potentials, depending on the reduction or oxidation of $\mathrm{H}_{2} \mathrm{O}_{2}$, respectively. Usually, with increasing $\left[\mathrm{H}_{2} \mathrm{O}_{2}\right]$, the corresponding peak currents also increase, and thus allow calibration. In SWV experiments, for instance, the voltammetric peak, which is termed net peak, is calculated as a difference of the corresponding peaks of the subsequent oxidation and reduction processes at the electrode surface, and the net peak commonly increases in proportion to $\left[\mathrm{H}_{2} \mathrm{O}_{2}\right]$. For calibration purposes, either the height of the peak relative to the baseline or, alternatively, the area under the peak is determined. As recently shown, ${ }^{122}$ both methods are effective to calibrate the current $-\left[\mathrm{H}_{2} \mathrm{O}_{2}\right]$ relationship. Another sophisticated approach to quantify the amount of various electrochemically active species, namely $\mathrm{H}_{2} \mathrm{O}_{2}$, peroxynitrite $\left(\mathrm{ONOO}^{-}\right), \mathrm{NO}^{-}$and $\mathrm{NO}_{2}^{-}$, all simultaneously released by stimulated cells of different types, was applied by Amatore and

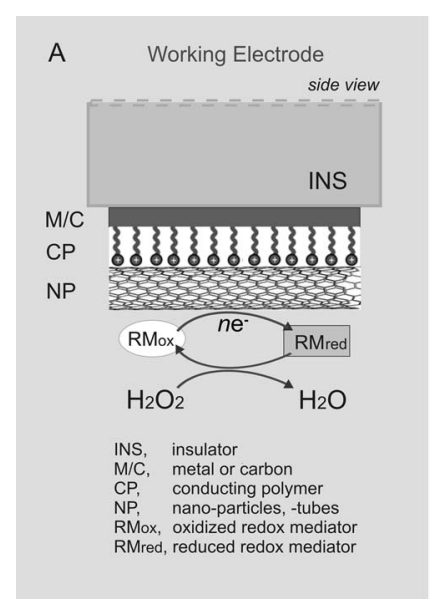

Second Generation of Electrochemical $\mathrm{H}_{2} \mathrm{O}_{2}$ Sensors

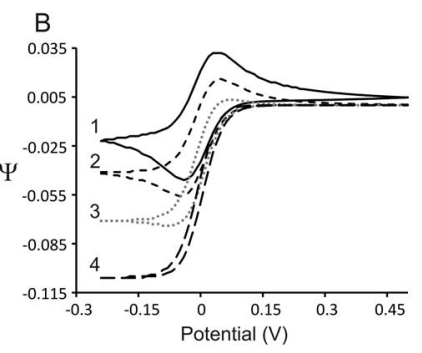
C Electrocatalytic Regenerative Mechanism EC'
$\mathrm{E}: \mathrm{RMox}+n \mathrm{e}^{\circ} \longrightarrow \mathrm{RMred}$

$C^{\prime}:$ RMred $+2 \mathrm{H}^{+}+\mathrm{H}_{2} \mathrm{O}_{2} \rightarrow \mathrm{RMox}+2 \mathrm{H}_{2} \mathrm{O}$

Figure 3. Second-generation electrochemical $\mathrm{H}_{2} \mathrm{O}_{2}$ sensors based on electrode surface modification and appropriate redox mediators. (A) The surface of a metal or carbon electrode $(\mathrm{M} / \mathrm{C})$ is modified by assembling a layer of conducting material (CP), to which nano-particles (NP) easily attach. Nano-sized materials can be single-walled or multi-walled carbon nanotubes, or graphene, which enlarge the active area of the electrode surface, thereby increasing sensitivity for $\mathrm{H}_{2} \mathrm{O}_{2}$. The surface-modified electrode is immersed into an electrolyte solution containing a redox mediator (RM), which shuttles electrons between the electrode and $\mathrm{H}_{2} \mathrm{O}_{2}$. The redox mediator might also be immobilized on the electrode surface. (B) Assumed theoretical cyclic voltammograms in the presence of a dissolved redox mediator in the absence (1) and presence of increasing $\left[\mathrm{H}_{2} \mathrm{O}_{2}\right](2-4) . \Psi$ stands for dimensionless current. (C) The redox mediator supports the electrochemical $\mathrm{H}_{2} \mathrm{O}_{2}$ determination by the electrocatalytic regenerative mechanism EC'. In the given example, electrons from the electrode reduce the oxidized form (RMox) of the redox mediator to yield the reduced form (RMred), which is thereafter recycled by the transfer of electrons to $\mathrm{H}_{2} \mathrm{O}_{2}$. Reduction by two electrons of one $\mathrm{H}_{2} \mathrm{O}_{2}$ molecule and reaction with $2 \mathrm{H}^{+}$leads to production of two molecules of $\mathrm{H}_{2} \mathrm{O} . n$, number of electrons.

co-workers. They conducted chronoamperometric and voltammetric measurements at platinized carbon-fiber microelectrodes. ${ }^{136}$ The specific potential for determination of particular species with chronoamperometry was defined in independent in-vitro voltammetric experiments. The amount of species released by the cell was determined by analyzing chronoamperometric experiments with the aid of Faraday's law. ${ }^{136}$

The hitherto described electrochemical detection of $\mathrm{H}_{2} \mathrm{O}_{2}$ at bare electrodes of different materials, applying voltammetric or chronoamperometric techniques, is related to the so-called first generation of electrochemical sensors (Figure 2). Although they are the simplest type of electrodes, some of them enable selective and sensitive determination of $\mathrm{H}_{2} \mathrm{O}_{2}$, and are still routinely applied.

Second-generation electrochemical $\mathrm{H}_{2} \mathrm{O}_{2}$ sensors.-Further methodological development, mainly focused to overcome the slow electrode kinetics of $\mathrm{H}_{2} \mathrm{O}_{2}$ at bare electrodes, resulted in the second generation of electrochemical sensors (Figure 3).

They are represented by surface-modified electrodes with electroconductive and electro-catalytic materials. ${ }^{130,137,138}$ These can be nanoparticles of noble metals, most frequently gold, ${ }^{139}$ goldplatinum, ${ }^{140}$ silver and/or platinum, ${ }^{141-145}$ or palladium. ${ }^{146}$ Other electrode modifications applying two metals or composites of a metal with various chemical substances, respectively, should also be mentioned here. ${ }^{147-157}$ Furthermore, metal oxides, ${ }^{15-160}$ carbon-derivatives, and conducting polymers have been employed to lower the overpotential of $\mathrm{H}_{2} \mathrm{O}_{2}$ electrode transformations. ${ }^{98,161-166}$ The diamine-based polymer, applied by Wilson et al. ${ }^{113}$ to cover carbon fiber electrode tips, enabled the small molecule $\mathrm{H}_{2} \mathrm{O}_{2}$ to penetrate the layer, but not larger molecules, which were also present in the surrounding solution and had redox potentials near to the one of $\mathrm{H}_{2} \mathrm{O}_{2}$. Thus, selectivity of the sensor for $\mathrm{H}_{2} \mathrm{O}_{2}$ was achieved by a "size-exclusion" mechanism of the polymer. 
An overview on a multitude of studies that have been performed to optimize electrode properties with regard to sensitivity, stability and selectivity is given by Alkire et al. ${ }^{135}$

An electrochemical method, called "self-assembling" is the most convenient way to cover carbon or metallic electrode surfaces with inorganic or organic polymers or with poly-electrolytes. ${ }^{161,166-169}$ In particular, thiol-containing compounds turned out to be useful surface modifiers for gold electrodes. ${ }^{135,170}$ Due to direct binding of sulfur to gold, sulfur-containing substances firmly attach to the electrode surface, mediating the redox transformations of $\mathrm{H}_{2} \mathrm{O}_{2}$. With those electrodes, lower detection limits for $\mathrm{H}_{2} \mathrm{O}_{2}$ in the micro- to nanomolar concentration range could be obtained. ${ }^{170}$ Other substances, like derivatives of amino acids, ${ }^{164}$ pyrrole, aniline, pyridine or diverse heterocyclic compounds ${ }^{171}$ are also used as efficient electrode modifiers. ${ }^{135}$

A breakthrough to more efficient surface modification was achieved by utilizing special nanocomposite materials, embedding nano-sized noble metal, which have strong electro-catalytic properties. ${ }^{99,120,124,141,165,172-183}$ Here, a series of sophisticated, but rather complex electrodes, modified with conducting polymers combined with metal or carbon nanoparticles have to be mentioned. ${ }^{184-192}$ Carbon nanomaterials, ${ }^{98,120}$ represented by single-layer sheets, singlewalled $^{193}$ or multi-walled carbon nanotubes, ${ }^{194,195}$ offer multiple binding sites for a variety of organic and inorganic compounds, which may further improve selective $\mathrm{H}_{2} \mathrm{O}_{2}$ measurements with low detection limits in the nanomolar range. Combination of particles of two different metals ("bi-metallic") are also applied for electrochemical $\mathrm{H}_{2} \mathrm{O}_{2}$ detection. ${ }^{99,140,196-201}$ In certain cases, bi-metallic nanoparticles are additionally stabilized by thiols to optimize further the electrochemical sensing capabilities. ${ }^{202}$

For several types of modified electrochemical second-generation sensors it turned out that they could be applied for detection of $\mathrm{H}_{2} \mathrm{O}_{2}$ and in parallel, for another substance; yet under respective adaptations of electrochemical parameters. Wang et al. introduced Pt-based sensors for $\mathrm{H}_{2} \mathrm{O}_{2}$ and glucose, ${ }^{203,204}$ and Cheng et al. recently presented an electrode for both, $\mathrm{H}_{2} \mathrm{O}_{2}$ and nitrite determination. ${ }^{205}$ Likewise, such dual-mode sensors can also be found among the third-generation electrochemical sensors.

Redox mediators. - Application of redox mediators is another important improvement for electrochemical sensors (Figure 3) to facilitate the electron exchange between the electrode and $\mathrm{H}_{2} \mathrm{O}_{2} \cdot{ }^{206}$ Commonly applied redox mediators are metal complexes (mainly iron complexes), which exhibit a reliable electrochemical reversibility. Some of them are sparingly water-soluble compounds, such as ferrocene derivatives, ${ }^{207}$ Prussian Blue, ${ }^{208,209}$ iron oxides ${ }^{210}$ and other metal derivatives. ${ }^{211,212}$ For $\mathrm{H}_{2} \mathrm{O}_{2}$ measurements, such mediators are effectively immobilized on the electrode surface by adsorption, exhibiting very sensitive mediation properties. In some cases, water-soluble metal complexes are also used as mediators; ${ }^{161,166}$ they are listed in Ref. 213. In the presence of $\mathrm{H}_{2} \mathrm{O}_{2}$, both types of redox mediators operate according to the socalled "electro-catalytic regenerative mechanism" [EC' mechanism; introduced by Testa and Reinmuth, 1961 $\left.{ }^{104,106,214-216}\right]$. The EC' mechanism couples the electrode reaction of the redox mediator $\left(\mathrm{RM}_{\mathrm{ox}} ; \mathrm{E}\right.$ step) and the follow up redox reaction between the electrochemically transformed redox mediator $\left(\mathrm{RM}_{\text {red }}\right)$ and $\mathrm{H}_{2} \mathrm{O}_{2}$ (C' step). Assuming an overall reductive mechanism, the EC' reaction scheme is represented by the following equations (also shown in Figure 3):

$$
\begin{gathered}
\mathrm{E}: \mathrm{RM}_{\mathrm{ox}}+n \mathrm{e}^{-} \leftrightarrow \mathrm{RM}_{\mathrm{red}} \\
\mathrm{C}^{\prime}: \mathrm{RM}_{\mathrm{red}}+\mathrm{H}_{2} \mathrm{O}_{2}+2 \mathrm{H}^{+} \rightarrow \mathrm{RM}_{\mathrm{ox}}+2 \mathrm{H}_{2} \mathrm{O}
\end{gathered}
$$

By this mechanism, $\mathrm{H}_{2} \mathrm{O}_{2}$ undergoes electrochemical transformation at the formal potential of the redox mediator, which ideally should be significantly lower than the high overpotential needed for direct electrode reaction of $\mathrm{H}_{2} \mathrm{O}_{2}$. A simulation of the voltammetric (CV) $\mathrm{H}_{2} \mathrm{O}_{2}$ determination using the above reaction schemes is given in Figure $3 \mathrm{~B}$. The voltammograms shown are typical for the EC' regenerative redox mechanism. Using redox mediators, detection limits for $\mathrm{H}_{2} \mathrm{O}_{2}$ range from 1 to $20 \mu \mathrm{M}$. The major drawback of the voltammetric sensors based on the EC' mechanism is their low selectivity, because

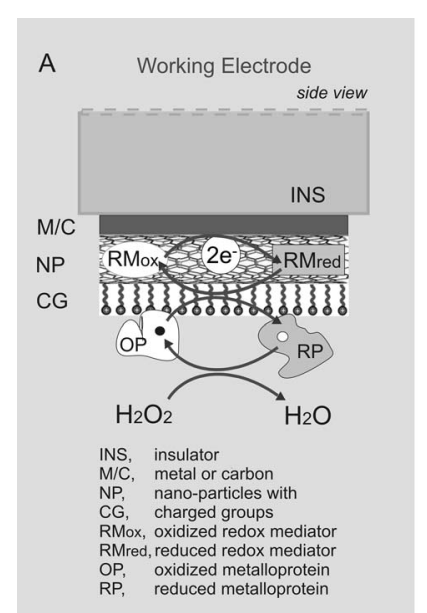

Third Generation

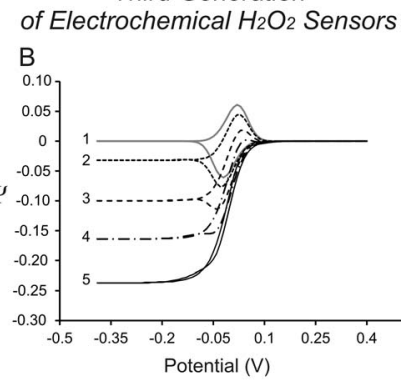

C Redox Protein-mediated $\mathrm{H}_{2} \mathrm{O}_{2}$ Measurement $\mathrm{RMox}+2 \mathrm{e}^{-} \rightarrow$ RMred RMred + OP $\rightarrow$ RMox + RP

Figure 4. Third-generation electrochemical $\mathrm{H}_{2} \mathrm{O}_{2}$ sensors. (A) Modifying the electrode surface includes assembly of nano-particles (NP) with an immobilized redox mediator (RMox) and charged groups (CG) to the metal or carbon $(\mathrm{M} / \mathrm{C})$ surface. A selected native redox (metallo) protein (OP, RP) with high affinity for $\mathrm{H}_{2} \mathrm{O}_{2}$ is then mounted to the pre-conditioned surface. Proteins can, for example, be molecules containing the prosthetic heme group, like hemoglobin, myoglobin, and cytochromes, but also the (metallo) enzymes catalase and horseradish peroxidase. The orientation of the protein should enable access of $\mathrm{H}_{2} \mathrm{O}_{2}$ to the active site of the prosthetic group represented by a black and a white circle in OP and RP, respectively. (B) Assumed theoretical cyclic voltammograms in the absence (1) and presence of increasing $\left[\mathrm{H}_{2} \mathrm{O}_{2}\right](2-$ 5; deoxygenated solution) measured with an electrode modified as described in (A). $\Psi$ stands for dimensionless current. (C) Electrodes, carrying native redox proteins, are characterized by fast interfacial electron transfer, high selectivity and sensitivity for $\mathrm{H}_{2} \mathrm{O}_{2}$. At a selected potential, the electron transfer cascade starts with the reduction of a redox mediator (RMox) by electrons of the electrode. The reduced redox mediator (RMred) is "recycled" by shuttling electrons to the oxidized form of the redox protein (OP). In the case of heme proteins, $\mathrm{Fe}^{3+}$ thereby is reduced to $\mathrm{Fe}^{2+}$. The resulting reduced protein (RP) can now be re-oxidized by $\mathrm{H}_{2} \mathrm{O}_{2}$ which is reduced. Depending on the redox protein, the presence or absence of interfacial nano-materials, and probably of additional redox mediators, the cascade can be even more complicated, and also can lead to the oxidative determination of $\mathrm{H}_{2} \mathrm{O}_{2}$

other oxidizing agents, present in the system in addition to $\mathrm{H}_{2} \mathrm{O}_{2}$, may interfere in the course of the $\mathrm{H}_{2} \mathrm{O}_{2}$ determination.

Third-generation electrochemical $\mathrm{H}_{2} \mathrm{O}_{2}$ sensors.-To further improve the technology, third-generation voltammetric sensors for $\mathrm{H}_{2} \mathrm{O}_{2}$ determination have been developed, which involve modification of electrodes with a variety of proteins and redox enzymes (Figure 4).

Electrochemical systems of such type are considered to be efficient tools to mimic redox processes in living organisms. For $\mathrm{H}_{2} \mathrm{O}_{2}$ determination, a selected enzyme or a non-enzymatic protein is immobilized on the electrode surface, ${ }^{217-222}$ which specifically reacts with $\mathrm{H}_{2} \mathrm{O}_{2}$, thus mediating the electron transfer with the electrode. Frequently applied enzymes are horseradish peroxidase ${ }^{187,223-234}$ and catalase, ${ }^{187,235-239}$ but also other proteins, such as heme or hemoglobin, ${ }^{240-244}$ myoglobin ${ }^{245-248}$ and cytochromes. ${ }^{228,249-253}$ For all of them, the redox couple $\mathrm{Fe}^{2+} / \mathrm{Fe}^{3+254,255}$ within the prosthetic group of the protein plays a critical role in mediating the electron transfer between $\mathrm{H}_{2} \mathrm{O}_{2}$ and the electrode. Another report described an amperometric sensor for $\mathrm{H}_{2} \mathrm{O}_{2}$ based on a combined modification with porous nickel hydroxide and cytochrome c..$^{256}$

Redox mediators.-Functioning of protein-based electrochemical sensors can be improved further by addition of soluble or surfaceimmobilized redox mediators to the aqueous electrolyte solution, such as hexacyanoferrates, ferrocene derivatives, methylene blue or quinones. ${ }^{257}$ Figure 4 summarizes the structural composition of the modified electrode surface (Figure 4A), and the sequence of redox Reactions $(5,6,7$; see below) at a (metallo) protein-modified electrode for $\mathrm{H}_{2} \mathrm{O}_{2}$ determination in the presence of a surface immobilized 
redox mediator (RM), and in a deoxygenated solution, assuming a reductive electrode mechanism (Figure 4C; metalloprotein $_{\mathrm{ox}}=\mathrm{OP}$ and metalloprotein $_{\text {red }}=\mathrm{RP}$ ):

$$
\begin{gathered}
\mathrm{RM}_{\mathrm{ox}}+2 \mathrm{e}^{-} \rightarrow \mathrm{RM}_{\mathrm{red}} \\
\text { metalloprotein }_{\mathrm{ox}}+\mathrm{RM}_{\mathrm{red}} \rightarrow \text { metalloprotein }_{\mathrm{red}}+\mathrm{RM}_{\mathrm{ox}}
\end{gathered}
$$

metalloprotein $_{\text {red }}+\mathrm{H}_{2} \mathrm{O}_{2}+2 \mathrm{H}^{+} \rightarrow 2 \mathrm{H}_{2} \mathrm{O}+$ metalloprotein $_{\mathrm{ox}}$

$$
\text { Overall reaction: } \mathrm{H}_{2} \mathrm{O}_{2}+2 \mathrm{e}^{-}+2 \mathrm{H}^{+} \rightarrow 2 \mathrm{H}_{2} \mathrm{O}
$$

Simulated CV experiments (Figure 4B) show changes in the voltammogram upon sequential addition of $\mathrm{H}_{2} \mathrm{O}_{2}$ (1, blank; 2, 3, 4, 5 after stepwise application of $\mathrm{H}_{2} \mathrm{O}_{2}$ ) using a modified electrode as shown in Figure 4A and assuming reduction of $\mathrm{H}_{2} \mathrm{O}_{2}$.

Depending on the protein chosen to modify the electrode surface, high selectivity for $\mathrm{H}_{2} \mathrm{O}_{2}$ can be achieved, and the lower detection limits range from $40 \mathrm{nM}$ to $10 \mu \mathrm{M}$, referring to the studies cited above in this paragraph and. ${ }^{223,258-268}$

It is finally worth to mention that protein-modified electrodes are associated with some disadvantages such as: $(i)$ preparation of the electrodes is time-consuming, as they have to be frequently renewed; (ii) preparation might be expensive in the case of a high price protein; (iii) activity of the enzyme can rapidly decrease because of denaturation; (iv) enzyme orientation on the electrode surface might be incorrect leading to impairment of catalytic activity:227,269,270 $(v)$ electrolytes in the measuring buffer may affect the activity, especially of redox enzymes. ${ }^{271}$

Another particular electrode type and measuring concept needs to be pointed out here. The research group of $\mathrm{Li}$ et al. ${ }^{272}$ described fabrication of an electrochemical sensor with a sensitivity for $\mathrm{H}_{2} \mathrm{O}_{2}$ of $10 \mathrm{fM}$, and a linear response from $100 \mathrm{pM}$ to $10 \mathrm{nM}$. For the sensor, nano porous gold films were covered with iron-containing heterocyclic compounds, which, in $\mathrm{N}_{2}$-saturated PBS buffer, undergo a series of complex reactions upon addition of $\mathrm{H}_{2} \mathrm{O}_{2}$. The mechanism to determine $\mathrm{H}_{2} \mathrm{O}_{2}$ is a "nonelectrocatalytic" (as called by Li et al.) indirect process which offers remarkably high sensitivity.

Screen-printed electrochemical sensors.-Screen-printed electrodes for $\mathrm{H}_{2} \mathrm{O}_{2}$ determination represent a recent development in sophisticated tool manufacturing. In the example reported by Cinti et al. ${ }^{273}$ the sensor printed with graphite-based conductive ink was additionally modified by Prussian Blue nanoparticles. For 20 layer-by-layer applications of the particles, piezoelectric inkjet printing was used. With this sensor, a low detection limit for $\mathrm{H}_{2} \mathrm{O}_{2}$ of $200 \mathrm{nM}$ could be achieved. Another inkjet-printed highly selective $\mathrm{H}_{2} \mathrm{O}_{2}$ sensor based on $\mathrm{Ti}_{3} \mathrm{C}_{2}$-graphene oxide was presented by Zheng et al. The lower detection limit was reported to be $1.95 \mu \mathrm{M} \cdot{ }^{274}$ More sensitive for $\mathrm{H}_{2} \mathrm{O}_{2}(13.7 \mathrm{nM})$ were carbon screen-printed electrodes with osmiumwired horseradish peroxidase modifications. ${ }^{275}$ Already in 2003, Xu et al. presented $\mathrm{H}_{2} \mathrm{O}_{2}$ sensors functionalized as colloidal gold modified screen-printed carbon electrodes. The enzyme horseradish peroxidase was additionally immobilized on the electrode, which then showed sensitivity for $\mathrm{H}_{2} \mathrm{O}_{2}$ in the range of 400 to $800 \mathrm{nM}{ }^{276}$

Graphene-modified electrodes.-Enormous progress in material sciences was made by the discovery of graphene in $2004 .{ }^{277}$ Because of its outstanding properties for electrochemical $\mathrm{H}_{2} \mathrm{O}_{2}$ sensing, it should be briefly addressed here. Graphene consists of a monolayer of carbon atoms, which constitute a 2 -dimensional crystal. Due to the unique physical and chemical properties it can also form 3-dimensional structures of various types, for instance nanotubes. ${ }^{93,278-280}$ The extraordinary high electrical conductivity and large active area make graphene an optimal material for electrode modification, substantially improving electron transfer towards/from the electrode surface. In addition, graphene-based materials can properly function as immobilization matrices for proteins, which selectively interact with $\mathrm{H}_{2} \mathrm{O}_{2}$. Numerous comprehensive and critical reviews have highlighted the impact of graphene in electrochemistry in general, particularly for $\mathrm{H}_{2} \mathrm{O}_{2}$ determination. ${ }^{30,281-288}$ Glassy carbon electrodes have been modified with graphene or graphene oxide ${ }^{289,290}$ resulting in a detection limit for $\left[\mathrm{H}_{2} \mathrm{O}_{2}\right]$ of $50-700 \mathrm{nM}$.

Furthermore, graphene or graphene-oxide supported sensors have been fabricated with native enzymes, like horseradish peroxidase or catalase, with other proteins, like hemoglobin, myoglobin ${ }^{290,291}$ or cytochrome c, with noble- or ignoble-metal materials ${ }^{252,292-305}$ or with Prussian Blue [iron(III)hexacyanoferrate(II); ${ }^{306}$ ]. Work of Li, F. et al. from $2011^{307}$ is a representative example for a sensitive microelectrode-array (MEA) sensor based on reduced graphene oxide and Prussian Blue, attributed with a detection limit of $10 \mathrm{nM}$. In addition, very complex hybrid-film based electrochemical sensors, incorporating graphene, have been used for $\mathrm{H}_{2} \mathrm{O}_{2}$ determinations with an impressive sensitivity. ${ }^{308,309}$ Specifically, depending on the respective combination of graphene or graphene oxide with additional materials, the detection limit for $\mathrm{H}_{2} \mathrm{O}_{2}$ ranges from $6 \mathrm{pM}$ up to $10 \mu \mathrm{M}$ concentrations [compare tables 1,2 and 3 in the recent review by Zhang et al. ${ }^{283}$ ].

Dual- and multi-mode sensors.-Some graphene-based or carbonnanotube sensors ( $3^{\text {rd }}$ generation) were fabricated in a way that allows determining two (or more) different substances with the same sensor, however applying specific settings of the measurement. $\mathrm{H}_{2} \mathrm{O}_{2}$ was measured in parallel to glucose, ${ }^{204,310-313}$ cholesterol, ${ }^{314}$ peracetic acid, ${ }^{315}$ ethanol, ${ }^{316}$ hydrazine ${ }^{163}$ or gallic acid. ${ }^{317}$ Specifically modified multi-walled carbon nanotubes (MWCNT) were reported to be appropriate sensors for $\mathrm{H}_{2} \mathrm{O}_{2}$ and iodate or bromate, respectively. ${ }^{238,244}$ For simultaneous determination of $\mathrm{H}_{2} \mathrm{O}_{2}$, glucose and ethanol, $\mathrm{Xu}$ et al. ${ }^{318}$ fabricated a unique nano-porous Pt-Co alloy. Zhang et al. determined $\mathrm{H}_{2} \mathrm{O}_{2}$ and nitrite chronoamperometrically at potentials of $-0.2 \mathrm{~V}$ and $+0.85 \mathrm{~V}$, respectively, with a single copper-oxide modified glassy carbon electrode and achieved a detection limit of $1.6 \mu \mathrm{M}$ for $\mathrm{H}_{2} \mathrm{O}_{2}$ and of $360 \mathrm{nM}$ for nitrite. ${ }^{319}$ Another electrochemical sensor for $\mathrm{H}_{2} \mathrm{O}_{2}$ and nitrite, fabricated as carbon-nanoparticle composite films was introduced. ${ }^{320}$ For the construction of the working electrode, first, carbon nanoparticles $(\mathrm{CN})$ were electropolymerized on the surface of a glassy carbon (GC) electrode of $3 \mathrm{~mm}$ diameter (giving a CN/GC composition). Thereafter, two more layers were disposed on the electrode: multi-walled carbon nanotubes (MWCNT) and a final chitosan film (CS). Using this "CS/MWCNT/CN/GC" sensor, $\mathrm{H}_{2} \mathrm{O}_{2}$ could be specifically determined by reduction and $\mathrm{NO}_{2}{ }^{-}$by oxidation with lower detection limits of $660 \mathrm{nM}$ and $890 \mathrm{nM}$, respectively.

$\cdot \mathrm{O}_{2}^{-}$and $\mathrm{H}_{2} \mathrm{O}_{2}$ measurements on living cells.-In contrast to in-vitro systems, as described in the foregoing sections, in-vivo or ex-vivo systems, like living cells, subcellular organelles, tissues or organs require different methods to detect and quantify ${ }^{\circ} \mathrm{O}_{2}{ }^{-}$and $\mathrm{H}_{2} \mathrm{O}_{2}$. Although the emphasis of the present review is on $\mathrm{H}_{2} \mathrm{O}_{2}$, its precursor $\cdot \mathrm{O}_{2}{ }^{-}$should also be briefly considered here.

- $\mathrm{O}_{2}{ }^{-}$determinations.-Since more than two decades, significant efforts have been made to determine ${ }^{\circ} \mathrm{O}_{2}{ }^{-}$produced by living cells. Because of the short in-vitro half-life of ${ }^{\circ} \mathrm{O}_{2}{ }^{-}$of about $2 \mu \mathrm{s},{ }^{321}$ its measurement is difficult. Additionally, extra- and intracellularly active superoxide dismutases (SOD) effectively convert ${ }^{\circ} \mathrm{O}_{2}{ }^{-}$to $\mathrm{H}_{2} \mathrm{O}_{2}$ in living systems. ${ }^{23,25}$ Due to its high affinity for ${ }^{\circ} \mathrm{O}_{2}^{-}$, the enzyme SOD was used to modify electrodes for monitoring of ${ }^{\circ} \mathrm{O}_{2}{ }^{-}$in statu nascendi, achieving considerably high sensitivity, with the lower detection limit ranging from 15 to $700 \mathrm{nM} .^{322-324}$ Another type of electrode modification by covalently immobilizing cytochrome $\mathrm{c}$ also turned out to be favorable to determine ${ }^{\circ} \mathrm{O}_{2}{ }^{-}$electrochemically. ${ }^{324-327}$ Cytochrome $\mathrm{c}$ is a small electron-transferring protein with a central heme group. Lower detection limits for ${ }^{\circ} \mathrm{O}_{2}{ }^{-}$, measured with such electrodes appeared to be in the same range as for SOD-modified sensors. For quantification of ' $\mathrm{O}_{2}{ }^{-}$released by cells, the above cited research groups performed calibrations with ${ }^{\circ} \mathrm{O}_{2}{ }^{-}$produced in vitro either by the xanthine/xanthine oxidase system or by $\mathrm{KO}_{2}$ dissolved in dimethyl sulfoxide. Currents measured from cellular material could thus be related to defined $\left[{ }^{\circ} \mathrm{O}_{2}{ }^{-}\right]$.

A remarkable study was done by Tanaka et al. in $1996,{ }^{328}$ who modified a simple carbon microelectrode of 6-8 $\mu \mathrm{m}$ diameter with dissolved fMLP, a signal-peptide for phagocytes. In phagocytotic cells, 
fMLP provokes an immune response including the "respiratory burst", which is characterized by a high amount of ${ }^{\circ} \mathrm{O}_{2}{ }^{-}$and $\mathrm{H}_{2} \mathrm{O}_{2}$ production outside the cell membrane. ${ }^{329}$ Upon attachment of a single phagocyte at the fMLP-modified electrode tip, ${ }^{\circ} \mathrm{O}_{2}{ }^{-}$of the "respiratory burst" was measured at a fA current level.

$\mathrm{H}_{2} \mathrm{O}_{2}$ determinations. - The study of O'Riordan et al. (2016) about in-vitro calibrations and ex-vivo measurements of $\mathrm{H}_{2} \mathrm{O}_{2}$ in explanted rat brain tissue is a representative example for the state-of-the-art determination of $\mathrm{H}_{2} \mathrm{O}_{2}$. With a bi-metallic electrode of $125 \mu \mathrm{m}$ tip diameter, modified with different materials, including the enzyme catalase, concentrations of $\mathrm{H}_{2} \mathrm{O}_{2}$ down to $75 \mathrm{nM}$ could be reliably detected. ${ }^{330}$ Another recent study ${ }^{190}$ describes direct measurements of $\mathrm{H}_{2} \mathrm{O}_{2}$ in the rat brain using a specially prepared microelectrode which was implanted (together with the reference and counter electrodes) into the organ of the anaesthetized animal. Dynamic $\left[\mathrm{H}_{2} \mathrm{O}_{2}\right]$ changes in the micromolar range could be resolved with high selectivity. The group of Reid et al. ${ }^{331}$ described amperometric $\mathrm{H}_{2} \mathrm{O}_{2}$ determinations in the intact and explanted brain as well as in brain homogenates of the mouse with a biosensor first presented by O'Brien et al. ${ }^{235}$ The implantable biosensor comprised two electrodes, one of which was a blank $\mathrm{Pt} / \mathrm{Ir}$ wire (for $\mathrm{H}_{2} \mathrm{O}_{2}$ measurement) and the other had been covered with catalase (for measurement of $\mathrm{H}_{2} \mathrm{O}_{2}$ degradation). The difference between the currents of the two electrodes was analyzed. The sensor engineered by Wilson et al. ${ }^{113}$ to measure $\mathrm{H}_{2} \mathrm{O}_{2}$ from brain slices of the rat was covered with a diamine-based polymer that let $\mathrm{H}_{2} \mathrm{O}_{2}$ pass the pores ("size-exclusion membrane"), but excluded larger molecules. Applying fast scan voltammetry, the researchers monitored $\mathrm{H}_{2} \mathrm{O}_{2}$ dynamics and in parallel, $\mathrm{pH}$ changes in real-time.

All studies referenced above within the $\mathrm{H}_{2} \mathrm{O}_{2}$ determinations section could be promising to provide an insight into the overall ROS balance of a complete organ.

There are a variety of techniques to determine $\mathrm{H}_{2} \mathrm{O}_{2}$ produced by cell clusters or cell suspensions, using electrodes modified with a broad spectrum of materials, such as nanoparticles and nanospheres of different types, also graphene-based, or by using arrays of electrodes or specially designed chips. In the case of chips, either many small electrodes, which can be controlled separately, are collocated, or the classical 3-electrode configuration is implemented. . $^{6,181,292,332-346}$ Detection limits for $\mathrm{H}_{2} \mathrm{O}_{2}$ range from $10 \mathrm{nM}$ up to $3 \mathrm{mM}$.

In a recent study, Zhu et al. ${ }^{347}$ applied a hybrid nanocomposite to measure $\mathrm{H}_{2} \mathrm{O}_{2}$ from fMLP-stimulated living murine breast cancer 4T1 cells in the absence of oxygen $\left(\mathrm{N}_{2}\right.$-saturated buffer). The PtW/MoS nanocomposite sensor was synthesized "through in-situ growth of PtW nanocrystals on the surface of $\mathrm{MoS}_{2}$ nanosheets". With their electrochemical device they could determine as low as $5 \mathrm{nM} \mathrm{H}_{2} \mathrm{O}_{2}$, as proved by addition of $\mathrm{H}_{2} \mathrm{O}_{2}$ to the test solution. From a physiological point of view, it is, however, questionable how the cells could survive in the absence of oxygen and how they produced ${ }^{\circ} \mathrm{O}_{2}{ }^{-}$(as a precursor of $\mathrm{H}_{2} \mathrm{O}_{2}$ ) without $\mathrm{O}_{2}$ accepting electrons.

Scanning electrochemical microscopy (SECM). - Since the first description in $1989,{ }^{348}$ SECM is a commonly applied technique to gain insight into technical issues, like corrosion, but also to directly probe individual cells or cell clusters. It enables investigation of electrochemical activity on the surface of a specimen with spatial resolution. The book of A.J. Bard and M.V. Mirkin, published in 2012, provides considerably detailed information about the technique. ${ }^{213}$ Overviews by other groups focus on special aspects of SECM. ${ }^{349-361}$ A related version of SECM called "alternating-current SECM" (AC-SECM) allows insight into both, topographical and biochemical properties of a specimen, e.g., a living cell. ${ }^{362,363}$

SECM is an amperometric method by which the current at a working (ultra-)microelectrode is measured as a function of an independent variable, typically time or voltage, as commonly done in an electrochemical experiment. However, the unique ability of SECM is that the response of the electrode essentially depends on its distance to the measured substrate, providing additional information on the spatial distribution of the studied electrochemically-active species. To electrochemically sense $\mathrm{H}_{2} \mathrm{O}_{2}$ originating from living specimen ("substrate"), the substrate generation/tip collection (SG-TC) mode of SECM is used. As collecting tips, either single ultramicroelectrodes (UMEs), arrays of UMEs (e.g., on a chip) or nanodes, ${ }^{364}$ can be applied. ${ }^{213,228,229,365-367}$ Usually, a single UME is disk-shaped, since such geometry offers higher sensitivity than electrodes of other shapes. ${ }^{213}$ Electrochemical properties of UMEs with a tip diameter less than $25 \mu \mathrm{m}$ substantially differ from bigger electrodes. ${ }^{103,106,364,368-370}$ In a solution with a supporting electrolyte, mass transport in the vicinity of the UME surface is mainly governed by diffusion, reaching steady-state and time-independent conditions within a fraction of a second. Usually, current values measured with UMEs are in the femtoA to nanoA range; therefore, resistive drops of the current in the electrolyte solution are negligible. These properties enable UMEs to provide electrochemical data of superior quality.

Additionally, chronoamperometric monitoring of (single) cells at a high frequency of current sampling, such as $1-1000 \mathrm{~Hz}$, allows detection of fast kinetics with sufficiently high time resolution. These facts, together with a fast response time of the sensor, make real-time monitoring of $\mathrm{H}_{2} \mathrm{O}_{2}$ in living systems possible.

The tip size of UMEs should be appropriate to scan cells with a diameter of a few micrometers, and the smaller the tip the higher the spatial resolution. The RG value of the UME (ratio of insulator thickness to radius of the conducting tip; see Figure 5B) is of minor importance, if analytes in the bulk solution are to be determined; however, it plays a crucial role when scanning single cells for production of redox active metabolites, like $\mathrm{H}_{2} \mathrm{O}_{2}$. RG values of 1.5 to 3 are optimal to guarantee efficient collection of species in real-time ${ }^{371}$ and to provide a high spatial resolution. Tips of representative UMEs, which revealed brilliant performance, are shown in Figures 5A and 5D and in Figure 6A.

To meet physiological conditions for living cells as closely as possible, electrochemical $\mathrm{H}_{2} \mathrm{O}_{2}$ measurements should be performed at temperatures of about $37^{\circ} \mathrm{C}$. When UMEs are being used in an unstirred electrolyte solution, this issue is rather challenging. Depending on the geometry of the UME, especially the length and shape of the tip, the material properties of the insulator, and other factors, signalto-noise ratio might worsen with increasing temperature (starting at about $28^{\circ} \mathrm{C}$ ). Irregular current fluctuations in broad frequency and amplitude spectra may overlay true signals to be measured (Bozem, unpublished observations). Several research groups have addressed this issue providing mathematical models as well as practical indications which can contribute to solve the problem..$^{271,372-375}$ Due to the higher-temperature related challenges it is not surprising that the majority of electrochemical $\mathrm{H}_{2} \mathrm{O}_{2}$ measurements are usually performed at room temperature and not at $37^{\circ} \mathrm{C}$.

It should also be noted that in experiments with aerobic living cells, oxygen is required. Its concentration is about $240 \mu \mathrm{M}$ in an ambient air-saturated buffer. When a Pt-UME is applied at potentials below $0 \mathrm{~V}$ (vs. $\mathrm{Ag} / \mathrm{AgCl}$ ), however, oxygen is reduced to ${ }^{\circ} \mathrm{O}_{2}{ }^{-}$and $\mathrm{H}_{2} \mathrm{O}_{2}$, known as oxygen reduction reaction. ${ }^{376}$ Hence, to avoid the interference of these reactive oxygen species with those produced by cells, determination of $\mathrm{H}_{2} \mathrm{O}_{2}$ by anodic oxidation at positive electrode potentials is advisable.

For extracellular $\mathrm{H}_{2} \mathrm{O}_{2}$ measurements, single cells, cell clusters or a slice of tissue have to be approached by the electrode tip as near as possible, but without touching the sample. Due to the hemispherical diffusion layer at the UME tip, ${ }^{213,377}$ an optimal distance between the tip and producing substrate should be in the range of the tip diameter. ${ }^{136}$ For adjustment and control of the tip-to-substrate distance, various approaches are possible, including shear force-based methods $^{378,379}$ or ion conductance microscopy [SICM; ${ }^{380-382}$ ]. A more simplified method is detailed in our recent study, ${ }^{122}$ where we used an inverted microscope to approach a single cell with the UME.

Electrochemical measurements of $\mathrm{H}_{2} \mathrm{O}_{2}$ with UMEs in the extracellular space near a single cell can be performed using voltammetric (like CV) and amperometric methods. In the experiment depicted in Figure $5 \mathrm{C}, \mathrm{H}_{2} \mathrm{O}_{2}$ was monitored chronoamperometrically at a constant potential of $650 \mathrm{mV}$ (vs. $\mathrm{Ag} / \mathrm{AgCl}$ ) over $70 \mathrm{~min}$ using a bare Pt-UME (white arrow in Figure 5D). After stimulation with a phorbol 

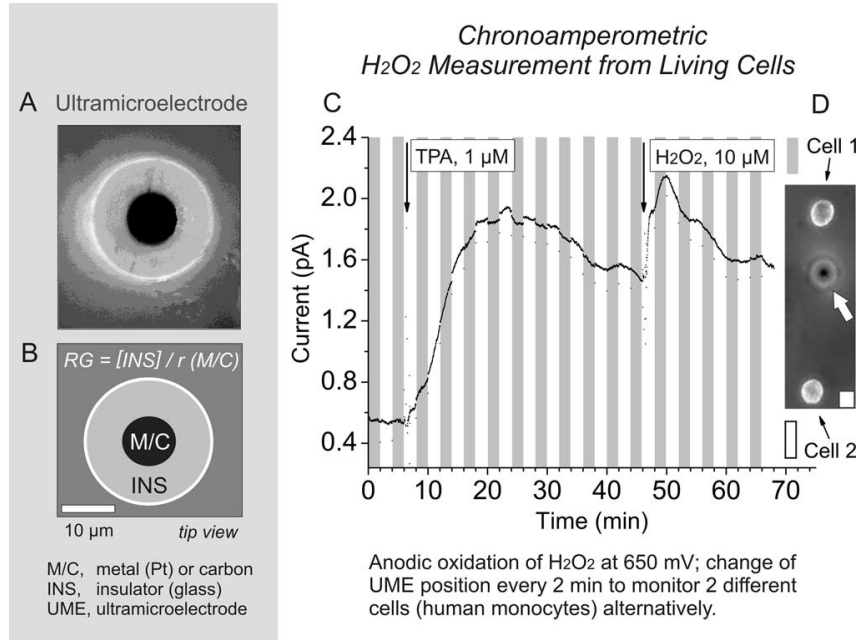

Anodic oxidation of $\mathrm{H}_{2} \mathrm{O}_{2}$ at $650 \mathrm{mV}$; change of UME position every 2 min to monitor 2 different cells (human monocytes) alternatively.

Figure 5. Electrochemical $\mathrm{H}_{2} \mathrm{O}_{2}$ measurements with ultramicroelectrodes. (A, B) To monitor $\mathrm{H}_{2} \mathrm{O}_{2}$ from single cells, cell clusters, and tissue slices requires electrodes with tip diameters of $\leq 25 \mu \mathrm{m}$, called ultramicroelectrodes (UME). Noble metal, like Pt, Au, or Ag, or carbon fibres are used as electrochemical sensors. They are applied in the bare state or after modification of the surface with various materials. In the exemplified bright-field image of a UME tip in (A), a bare Pt wire with $\mathrm{r}=5 \mu \mathrm{m}$ had been sealed into a borosilicate glass tube (INS). (B) is a schematic image of (A). The RG value of the UME, which is the ratio between the insulator thickness [INS] and the radius of the wire $[\mathrm{r}(\mathrm{M} / \mathrm{C})]$, is about 1.5 in the example shown in $(\mathrm{A})$. (C, D) Chronoamperometric measurement of extracellular $\mathrm{H}_{2} \mathrm{O}_{2}$ produced by two single primary human monocytes, depicted in (D) with the white square in the lower right corner indicating $10 \times 10 \mu \mathrm{m}$. In the presence of ambient air, anodic oxidation at the fixed potential of $650 \mathrm{mV}$ was used to determine $\mathrm{H}_{2} \mathrm{O}_{2}$ with a Pt-UME versus $\mathrm{Ag} / \mathrm{AgCl}$. The tip of the UME [white arrow in (D)] was placed above the cell surfaces with a vertical distance of 5-8 $\mu \mathrm{m}$ (constant height). Following a predefined protocol, the table with the cell dish was moved every $2 \mathrm{~min}$, so that the UME was exactly positioned above cell 1 , or alternatively above cell 2 . Cells were treated in a phosphate-buffered solution with the phorbol ester TPA and thereafter with externally applied $\mathrm{H}_{2} \mathrm{O}_{2}$. TPA stimulates NADPH oxidases in the cell membrane to produce ${ }^{\bullet} \mathrm{O}_{2}{ }^{-}$which is rapidly dismutated to $\mathrm{H}_{2} \mathrm{O}_{2}$. In the close vicinity of the cell, $\mathrm{H}_{2} \mathrm{O}_{2}$ is monitored in real-time as current change. Response-related current traces of cell 1 and cell 2 are shown in the gray and white 2-min intervals, respectively. Dynamics of the current traces reflect production (increase of current values) and degradation/elimination (decrease of current values) of $\mathrm{H}_{2} \mathrm{O}_{2}$ by the cells. With respective calibration experiments in the absence of cells, dynamics can be quantified. The presented technique thus allows single-cell as well as multi-cell measurements almost at the same time and enables studies of inter-related metabolic processes. A similar experiment has been presented in Ref. 122, and a detailed description of the applied method is given in this reference.

ester (TPA), both monocytes, shown in Figure 5D as cell 1 and cell 2, responded with production (increasing current) and subsequent elimination (decreasing current) of $\mathrm{H}_{2} \mathrm{O}_{2}$ at the outside. $\mathrm{H}_{2} \mathrm{O}_{2}$ diffuses into the cell and is effectively trapped and/or degraded by multiple intracellular reaction systems [compare ${ }^{48,122}$ ]. The special feature of this type of experiment is the almost simultaneous measurement of two cells, in this case sitting about $100 \mu \mathrm{m}$ apart from each other. By adapting the predefined measuring protocol, also more than two cells as well as dynamics of interacting cells in a multi-cellular system could be monitored with variable time intervals.

The classical biological SECM method is represented by the experiment shown in Figure 6B. Following predefined settings, an $\mathrm{H}_{2} \mathrm{O}_{2}$ producing single cell (MC in Figure 6A) is screened in a 2D-scan. In the constant-height mode of scanning, about 5-8 $\mu \mathrm{m}$ above the cell surface, areas of different $\left[\mathrm{H}_{2} \mathrm{O}_{2}\right]$ in the cell region (dashed white circle) could be resolved. Furthermore, the broad $\mathrm{H}_{2} \mathrm{O}_{2}$ diffusion area surrounding the producing cell was clearly visible. More detailed information about the technical settings of this method and its appli-

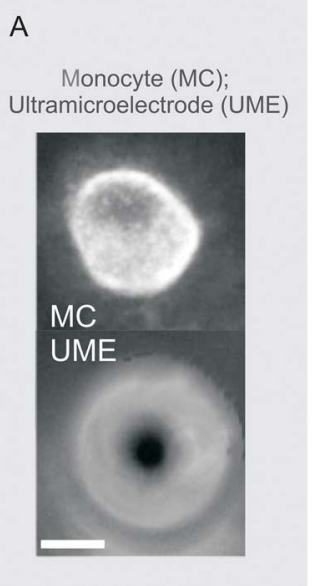

\section{Scanning Electrochemical Microscopy (SECM)} B

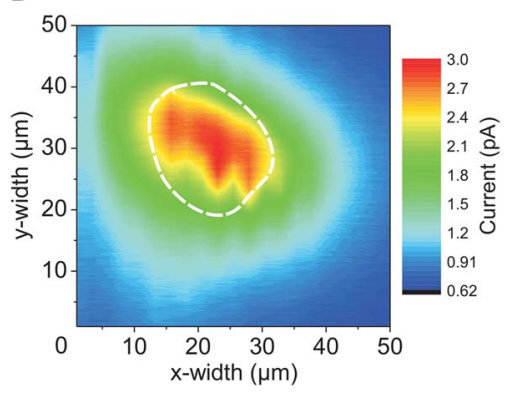

Chronoamperometric $\mathrm{H}_{2} \mathrm{O}_{2}$ measurement at $650 \mathrm{mV}$ with a Pt-UME versus $\mathrm{Ag} / \mathrm{AgCl}$.

Figure 6. Extracellular $\mathrm{H}_{2} \mathrm{O}_{2}$ measurement from a single cell with scanning electrochemical microscopy (SECM). (A) From a single primary human monocyte (MC), attached to the bottom of a dish, extracellular $\mathrm{H}_{2} \mathrm{O}_{2}$ was measured with a $10 \mu \mathrm{m}$ Pt-UME versus $\mathrm{Ag} / \mathrm{AgCl}$. The white bar in the lower left corner indicates $10 \mu \mathrm{m}$. The tip of the UME was placed above the cell at a vertical distance of 5-8 $\mu \mathrm{m}$ (constant height), followed by stimulation of the cell with the phorbol ester TPA $(1 \mu \mathrm{M})$ to induce $\mathrm{H}_{2} \mathrm{O}_{2}$ production. (B) About 5 min later, a 2D-scan of an area of $50 \times 50 \mu \mathrm{m}$, including the cell, was performed, starting in the lower right corner of the area. Along the $\mathrm{x}$-axis, the cell with its dish was moved by $1.5 \mu \mathrm{m} / \mathrm{s}$; scan lines alternated in the $+\mathrm{x}$ and $-\mathrm{x}$ directions, and were separated by $1.5 \mu \mathrm{m}$ in the y-direction. Simultaneously, $\mathrm{H}_{2} \mathrm{O}_{2}$ was measured (raw data, no compression); current values are reflected by colors, decoded in the heat map in (B). The dotted white circle in (B) marks the position of the scanned MC, which is shown in (A) with the same orientation and magnification. A similar experiment has been presented in Ref. 122 .

cation for single-cell measurements are given in the Materials and Methods section of Ref. 122.

To calibrate amperometric current values from cell experiments to $\mathrm{H}_{2} \mathrm{O}_{2}$ concentrations, measurements of defined concentrations of $\mathrm{H}_{2} \mathrm{O}_{2}$ (being added to the solution) should be done either in the absence of cells/tissues, or by placing the electrode tip far above the cell layer in a large volume of bulk solution ( $\geq 1 \mathrm{~mm}$ above), in order to avoid interference by cellular elimination/degradation of $\mathrm{H}_{2} \mathrm{O}_{2} .{ }^{122}$

In this context, the $\mathrm{pH}$ issue should also be considered. In artificial as well as in cellular systems, the superoxide radical anion ${ }^{\bullet} \mathrm{O}_{2}{ }^{-}$is formed by a $1 \mathrm{e}^{-}$transfer onto $\mathrm{O}_{2}$. To finally produce $\mathrm{H}_{2} \mathrm{O}_{2}$, another electron and $2 \mathrm{H}^{+}$have to be passed onto ${ }^{\circ} \mathrm{O}_{2}{ }^{-}$(proton-coupled electron transfer; compare also Figure 1), which could change $\mathrm{pH}$. In cell experiments, conducted in a buffered electrolyte solution at physiological $\mathrm{pH} \sim 7$, no changes in extracellular $\mathrm{pH}$ are to be expected, at least, not in the bulk solution. If the distance between the UME tip and the surface of a cell (producing $\mathrm{H}_{2} \mathrm{O}_{2}$ extracellularly from ${ }^{\bullet} \mathrm{O}_{2}^{-}$) is sufficiently large, there should also be plenty of protons steadily diffusing to the reaction site. During measurements within cells, tissues or whole organs, it can, however, not be excluded that $\mathrm{pH}$ changes occur along with $\mathrm{H}_{2} \mathrm{O}_{2}$ formation. As shown in two papers by the group of Sombers, ${ }^{13,383} \mathrm{pH}$ variations, monitored as electrochemical signals, can overlay signals caused by $\mathrm{H}_{2} \mathrm{O}_{2}$. For qualitative and especially, quantitative determinations of $\mathrm{H}_{2} \mathrm{O}_{2}$, the impact of eventual $\mathrm{pH}$ shifts should thus be taken into account.

Optimizing UME properties: Many investigations have been undertaken to optimize UME properties ${ }^{367,384}$ and electronic equipment (e.g., amplifiers) for SECM. Main intentions were to improve selectivity, sensitivity, signal-to-noise ratio, temporal and spatial resolution as well as longevity of the sensor. For UME modifications, in principle, approaches are similar as described for micro and macro electrodes. ${ }^{140,257,307}$ Efficient electron transfer at the electrode surface crucially depends on the number of active sites. To increase the active surface area without increasing the overall UME diameter, Amatore's group has applied a special modification: carbon-fiber 
electrodes of $10 \mu \mathrm{m}$ diameter are platinized electrochemically. ${ }^{385}$ Using these UMEs, a low $\left[\mathrm{H}_{2} \mathrm{O}_{2}\right]$ detection limit of $10 \mathrm{nM}$ was obtained. A similar approach to modify a carbon fiber microelectrode with $\mathrm{Pt}$ nanoparticles was reported by Chen et al.; the lower detection limit of this sensor was measured to be $44 \mu \mathrm{M}$ for $\left[\mathrm{H}_{2} \mathrm{O}_{2}\right] .{ }^{386}$ For determinations of $\mathrm{H}_{2} \mathrm{O}_{2}$ released from mitochondria, Ben-Amor et al. ${ }^{387}$ fabricated platinized UMEs and treated them with oxygen plasma, resulting in a 3 -fold decrease of capacitive current and a detection limit of $100 \mathrm{nM}$ for $\mathrm{H}_{2} \mathrm{O}_{2}$.

During the last decade, graphene in all its forms became the most important material to enlarge the active area of an electrochemical sensor (compare Graphene-modified electrodes and $\mathrm{H}_{2} \mathrm{O}_{2}$ determinations sections). For $\mathrm{H}_{2} \mathrm{O}_{2}$ determinations, graphene modifications of electrodes occasionally led to sensitivities in the subnanomolar range. Applying soluble redox mediators was also shown to improve electron transfer to/from the electrochemical sensor in SECM experiments with living cells. ${ }^{351,360,388,389}$

Combined electrochemical and fluorescence measurement: A combination of extracellular SECM (with a Pt-UME, $10 \mu \mathrm{m}$ diameter) and intracellular fluorescence-based ROS determination was described by Salamifar et al. ${ }^{390}$ in prostate cancer cells. Cells were loaded with the green-fluorescent carboxy- $\mathrm{H}_{2}$ DCFDA dye and both, fluorescence and electrochemical activity, were determined at the same time, after cells had been treated with a ROS stimulus. Extracellular "ROS levels" (presumably $\mathrm{H}_{2} \mathrm{O}_{2}$ ) were shown to be similar to intracellular "ROS levels". Although this type of experiment is very promising for a deeper understanding of ROS metabolism under physiological and pathological conditions, there are some potential pitfalls using this setup. The unspecific carboxy- $\mathrm{H}_{2}$ DCFDA should be replaced by a more specific dye for intracellular $\mathrm{H}_{2} \mathrm{O}_{2}$ monitoring. ${ }^{81}$ Furthermore, it is questionable, whether intra- and extracellular $\left[\mathrm{H}_{2} \mathrm{O}_{2}\right]$ can be the same, when the cell membrane is intact. It was shown previously that $\left[\mathrm{H}_{2} \mathrm{O}_{2}\right]$ gradients are established over the membrane ${ }^{67,391}$ and that cytoplasmic peroxiredoxins with very high affinity bind $\mathrm{H}_{2} \mathrm{O}_{2}$ to function as "redox relays". ${ }^{48,392}$ In addition, peroxiredoxins, like many other metabolites and enzymes contribute to the $\mathrm{H}_{2} \mathrm{O}_{2}$ buffering system within the cell thus avoiding toxic $\left[\mathrm{H}_{2} \mathrm{O}_{2}\right] .{ }^{393}$ For $\mathrm{H}_{2} \mathrm{O}_{2}$ detection in living cellular systems, $\mathrm{Ni}$ et al. ${ }^{394}$ fabricated a multichannel device containing a "fluorescence-electrochemistry combined probe". With this multimodul sensor, they were able to measure intracellular $\mathrm{H}_{2} \mathrm{O}_{2}$ and its release from stimulated RAW 264.7 macrophages. The authors also confirmed biocompatibility of the material components used for the sensor.

SECM on bacterial biofilms.-Bacteria can form colonies within a matrix of polymeric substances produced extracellularly. Within this film, bacteria communicate with each other using a mechanism, called "quorum sensing". ${ }^{395}$ By this mechanism, cell density, specific phenotype expressions, behavior and other bacterial functions are regulated. About $80 \%$ of chronic infections in humans are associated with biofilms. Antibiotics as well as defence mechanisms of immune cells often fail to combat the infections related to biofilms. ${ }^{396} \mathrm{Be}-$ sides those pathogenic bacteria, also beneficial species exist, which co-localize in biofilms. In the presence of oxygen, oral microbes for example, ferment carbohydrates to produce lactic acid and $\mathrm{H}_{2} \mathrm{O}_{2}$. Bard and co-workers monitored the $\mathrm{H}_{2} \mathrm{O}_{2}$ distribution in the biofilm of a mixed bacteria population using SECM and a gold electrode of $25 \mu \mathrm{m}$ diameter. ${ }^{397}$ Applying SECM with a Pt-UME, Zoski's group determined catalase activity in bacterial biofilms indirectly by measuring $\mathrm{H}_{2} \mathrm{O}_{2}$ decomposition. ${ }^{398}$ Electroactive biofilms form a part of so-called bio-electrochemical systems representing an advanced methodology for microbial fuel cell fabrication. ${ }^{399,400}$

Intracellular $\mathrm{H}_{2} \mathrm{O}_{2}$ measurements with nanoelectrodes (nanodes).Electroanalytical chemistry experiences substantial improvement by employing nanoelectrodes, which are characterized by tip dimensions at or below $100 \mathrm{~nm}$ and by high sensitivity and spatial resolution. ${ }^{401}$ For direct intracellular $\mathrm{H}_{2} \mathrm{O}_{2}$ measurement, nanoelectrodes (nanodes) were impaled into living cells. ${ }^{203,402,403}$ To avoid leakage of cellular material and influx of extracellular fluid into the cell and to minimize cellular stress upon puncture of the membrane, the total diameter of a nanoelectrode (glass sheath plus wire) should be in the range of 100 to $500 \mathrm{~nm}$ or even below. With small carbon nanoelectrodes (modified with Prussian Blue $=$ PB-CNEs) Schuhmann's group recently succeeded in determining $\mathrm{H}_{2} \mathrm{O}_{2}$ in the intracellular space of living cells. Calibrations with PB-CNEs, using cathodic current of $\mathrm{H}_{2} \mathrm{O}_{2}$ reduction showed linearity in the range of $10 \mu \mathrm{M}$ up to $3 \mathrm{mM}\left[\mathrm{H}_{2} \mathrm{O}_{2}\right] .{ }^{403}$ Such high global $\left[\mathrm{H}_{2} \mathrm{O}_{2}\right]$, however, are unlikely to be reached intracellularly, since multiple mechanisms lead to fast and effective clearance of $\mathrm{H}_{2} \mathrm{O}_{2}$, thus preventing damage of cellular components and enabling $\mathrm{H}_{2} \mathrm{O}_{2}$ signaling functions. ${ }^{48,122,392,404-406}$

A carbon nanotube-based electrochemical ROS sensor with elaborated modifications for intracellular measurements was also reported. ${ }^{407}$ Specifically functionalized nanowires (indium tin oxide, single-walled-carbon nanotubes $=$ ITO-SWCNTs) to which an osmium catalyst was attached, were forced to cross the membrane of RAW 264.7 macrophages by centrifugation at $3000 \mathrm{rpm}$. Immunological stimulation of the cells was followed by intracellular production of ROS which was determined electrochemically. The measurements and appropriate controls were validated with electron spin resonance spectroscopy (ESR). This centrifugation-based cell-invasive method, however, does not monitor the cells under physiological conditions, and it seems to disregard the strong dependency of cell metabolism on an intact cell membrane. Therefore, the contribution of this method to a better insight into the innate immune response of macrophages might be limited.

$\mathrm{H}_{2} \mathrm{O}_{2}$ production by isolated yeast mitochondria in suspension was determined by Arbault's group. ${ }^{234}$ Along the respiratory chain, a redox cascade located in the mitochondrial matrix, oxygen is reduced to water, and concomitantly, ATP and ${ }^{\circ} \mathrm{O}_{2}{ }^{-}$are formed. ${ }^{\circ} \mathrm{O}_{2}{ }^{-}$is effectively dismutated to $\mathrm{H}_{2} \mathrm{O}_{2}$ by mitochondrial Mn-SOD. In a closed oxygraphy chamber, the researchers determined oxygen consumption with a Clark-type electrode and in parallel, $\mathrm{H}_{2} \mathrm{O}_{2}$ with a microelectrode which had been prepared as follows: a 5 or $3 \mathrm{~mm}$ diameter glassy carbon electrode was covered with a 3D-linked "porous" polymer matrix including mobile osmium redox mediators. Additionally, the enzyme horseradish peroxidase (HRP) was embedded into the matrix. Within this setup, electrons are generated at a respective potential and are transferred along a cascade of redox processes to finally reduce the analyte at the electrode resulting in current changes. The extraordinary sensitivity of the sensor for $\mathrm{H}_{2} \mathrm{O}_{2}$ in the range of $1 \mathrm{nM}$, the linear response over a broad $\left[\mathrm{H}_{2} \mathrm{O}_{2}\right]$ spectrum and the fast response time should attract special interest. In another publication, the same group used an array-based electrochemical sensor for $\mathrm{H}_{2} \mathrm{O}_{2}$ measurements at isolated mitochondria. ${ }^{387}$ Already in 2012, Marcu et al. determined $\mathrm{H}_{2} \mathrm{O}_{2}$ production from isolated mitochondria of the mouse. ${ }^{408}$ For this, the researchers applied a platinized carbon fiber electrode of $10 \mu \mathrm{m}$ diameter, displaying a lower detection limit for $\mathrm{H}_{2} \mathrm{O}_{2}$ of $100 \mathrm{nM}$.

Instrumentation for electrochemical $\mathrm{H}_{2} \mathrm{O}_{2}$ determination.-The basic instrumental equipment for electrochemical measurements as listed in Table I (see Conclusive evaluations of electrochemical and ESR spectroscopic $\mathrm{H}_{2} \mathrm{O}_{2}$ (and ${ }^{\circ} \mathrm{O}_{2}^{-}$) determinations section) involves an amplifier to generate voltage and measure current, working, reference (and counter) electrodes and a head-stage to mount them. Devices to manage working electrode and specimen positions exist in simple and highly elaborated versions. Depending on experimental requirements, additional components are necessary: An illumination and a heating system, inverted microscope optics with appropriate objective(s) and a (CCD) camera. It is useful to mount the setup on a vibration-dampening table and to shield it in a Faraday cage. For controlling proper functioning of the components and collecting and processing measuring data, the software which is usually provided together with the hardware should cope with the requirements of the respective research project. There are several well-established providers worldwide who offer electrochemical instruments; occasionally researchers design and construct or modify equipment themselves to meet special demands. In our recently published article ${ }^{122}$ the electrochemical (SECM) setup to measure $\mathrm{H}_{2} \mathrm{O}_{2}$ from single cells (see also 


$$
\begin{aligned}
& \text { Electron Spin Resonance (ESR) } \\
& \text { Spectroscopy } \\
& >\text { Spin Trapping ESR for } \mathrm{H}_{2} \mathrm{O}_{2}< \\
& \mathrm{Fe}^{2+}+\mathrm{H}_{2} \mathrm{O}_{2} \longrightarrow \mathrm{Fe}^{3+}+\mathrm{HO}^{-}+\mathrm{OH}^{-} \\
& \left(k 1=63 \mathrm{M}^{-1} \mathrm{~s}^{-1}\right) \\
& \mathrm{Fe}^{3+}+\mathrm{H}_{2} \mathrm{O}_{2} \rightarrow \mathrm{Fe}^{2+}+{ }^{-} \mathrm{O}_{2}{ }^{-}+2 \mathrm{H}^{+} \\
& \left(k 2=0.01 \mathrm{M}^{-1} \mathrm{~s}^{-1}\right) \\
& 2 \mathrm{H}_{2} \mathrm{O}_{2} \stackrel{\mathrm{Fe}}{=} \mathrm{HO}^{-}+\mathrm{OH}^{-}+{ }^{\circ} \mathrm{O}_{2}{ }^{-}+2 \mathrm{H}^{+}
\end{aligned}
$$

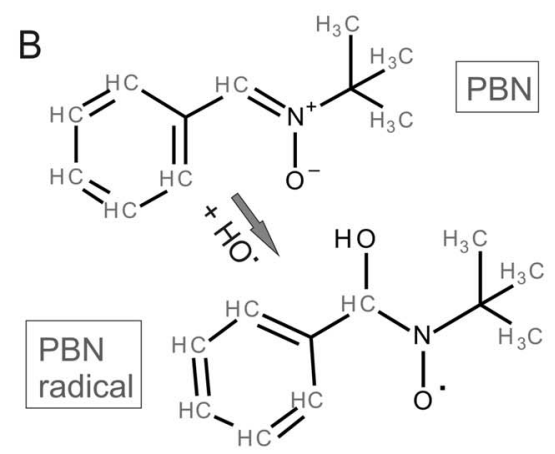

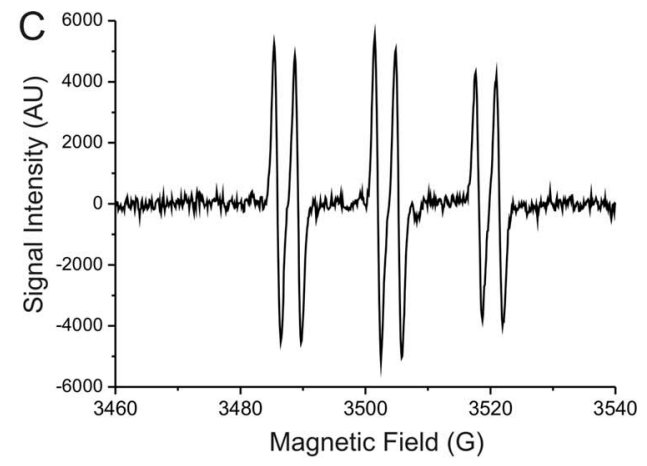

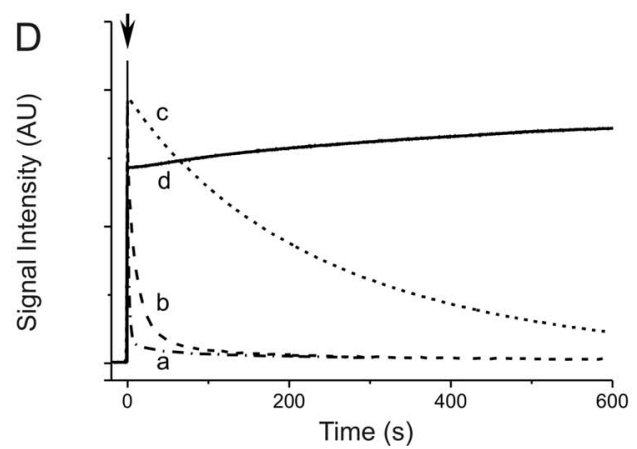

Figure 7. Fenton reaction as a chemical model for ESR spin trapping of radicals produced from $\mathrm{H}_{2} \mathrm{O}_{2}$. (A) The equations of catalytic $\mathrm{H}_{2} \mathrm{O}_{2}$ degradation indicate the formation of the radicals $\mathrm{HO}^{\circ}$ and ${ }^{\circ} \mathrm{O}_{2}^{-}$. (B) The chemical structure of the linear nitrone spin trap PBN is showing the reactive site to which $\mathrm{HO}^{\circ}$ binds. Its unpaired electron is stabilized on the nitroxide. (C) The ESR spectrum of the OH-PBN ${ }^{*}$ spin shows a typical line pattern. The large splitting (16 G) is caused by the nitrogen nuclear spin $I=1$, and the small splitting $(3 \mathrm{G})$ arises from the proton spin ( $\mathrm{I}=1 / 2)$ of the hydrogen closest to the nitroxide group. (D) After mixing and injecting a solution of PBN and $\mathrm{Fe}^{2+}$ and one with $\mathrm{H}_{2} \mathrm{O}_{2}$ within $5 \mathrm{~s}$ into an ESR flat cell, the time sweep measurement of the PBN-adduct spectra was started as indicated by the arrow. The intensity of the first line was recorded. Traces $a$ and $b$ are for PBN in pure water and phosphate buffer, respectively, showing a fast signal decay. The spin trap POBN (in buffer) was much more stable than PBN (trace $c$ ). Addition of ethanol (3\% v/v) to the buffered solution yielded a stable spin-adduct of hydroxyethyl radicals and $\mathrm{PBN}($ d $)$. Experimental conditions: $25 \mathrm{mM} \mathrm{PBN}$ and $\mathrm{POBN}, 1.4 \mathrm{mM} \mathrm{FeSO}_{4} \cdot 7 \mathrm{H}_{2} \mathrm{O}, 40 \mathrm{mM} \mathrm{H}_{2} \mathrm{O}_{2}, 100 \mathrm{mM} \mathrm{KH}_{2} \mathrm{PO}_{4} / \mathrm{K}_{2} \mathrm{HPO}_{4}\left(\mathrm{~K}_{\mathrm{phos}}\right)$ buffer $\mathrm{pH}$ 5; ESR: microwave power $20 \mathrm{~mW}$, modulation amplitude $1 \mathrm{G}$ in field sweep, $2 \mathrm{G}$ in time sweep.

Figures 5 and 6 of the present review article) is described in detail; it may be taken as an example.

\section{Measurement of $\mathrm{H}_{2} \mathrm{O}_{2}$ and Related ROS Radicals with Electron Spin Resonance (ESR) Spectroscopy}

The term electron spin resonance (ESR) is used equivalently to electron paramagnetic resonance (EPR). As shown in Figure $1, \mathrm{H}_{2} \mathrm{O}_{2}$ is formed from $\mathrm{O}_{2}$ by two $1 \mathrm{e}^{-}$-transfer processes which change the triplet state of oxygen to a diamagnetic singlet state. In biological systems, NOX enzyme complexes of certain cells produce ${ }^{\circ} \mathrm{O}_{2}^{-}$which is subsequently dismutated to $\mathrm{H}_{2} \mathrm{O}_{2}$ by SOD (compare Figure 1 ). Since $\mathrm{H}_{2} \mathrm{O}_{2}$ does not carry an unpaired electron spin, it is not directly accessible by ESR. This method relies on the presence of magnetic moments associated with at least one unpaired electron in any kind of radical, such as quinone radicals ${ }^{409}$ or transition metal ions.

Applications of spin traps and spin probes. $-\mathrm{H}_{2} \mathrm{O}_{2}$ is rather susceptible to redox reactions operating as an oxidant or reductant. When single electrons are transferred between reactants, radicals are generated from $\mathrm{H}_{2} \mathrm{O}_{2}$. The classical chemical example for such a process is the Fenton reaction, in which the catalytically active $\mathrm{Fe}^{2+}$ is oxidized to $\mathrm{Fe}^{3+}$, and the transferred electron is destabilizing $\mathrm{H}_{2} \mathrm{O}_{2}$, generating hydroxyl radicals and hydroxyl anions $\left(\mathrm{HO}^{\bullet}\right.$ and $\left.\mathrm{OH}^{-}\right)$with a high rate constant. In a second step, $\mathrm{Fe}^{3+}$ is reduced by $\mathrm{H}_{2} \mathrm{O}_{2}$, and ${ }^{\circ} \mathrm{O}_{2}{ }^{-}$is formed with a lower rate constant (Figure $7 \mathrm{~A}$ ). $\mathrm{HO}^{\circ}$ is highly oxidizing and very reactive; its lifetime is usually in the order of $10^{-9} \mathrm{~s}$ (compare Figure 1). The short lifetime in solution at room temperature makes direct detection by ESR impossible.

Spin traps and spin probes: For ESR measurements of such shortlived radical species, like the precursor ${ }^{\circ} \mathrm{O}_{2}{ }^{-}$and the break-down product $\mathrm{HO}^{\circ}$ of $\mathrm{H}_{2} \mathrm{O}_{2}$, spin traps are used. These specifically bind to the respective radical species resulting in a stable spin-adduct with a characteristic ESR signal, usually a nitroxide radical signal. But in case of ${ }^{\circ} \mathrm{O}_{2}{ }^{-}$, for example, kinetics of spin trapping can be relatively slow, which makes detection of the spin-adduct in living systems rather difficult and imprecise. In addition, intracellular anti-oxidative systems are degrading the spin-adducts quite rapidly to products which are no longer ESR-active. In this case, spin probes, mainly cyclic hydroxylamines, are useful, which react much faster with ${ }^{\circ} \mathrm{O}_{2}{ }^{-}$than spin traps, can compete with many anti-oxidative compounds, and are more resistant to degradation.

Spin trapping of $\mathrm{HO}^{*}$ : Reaction of $\mathrm{HO}^{*}$ with a spin trap leads to an ESR-active spin-adduct with a much longer lifetime compared to that of free $\mathrm{HO}^{\circ}$. A typical example is the linear nitrone spin trap PBN (N-tert-butyl- $\alpha$-phenylnitrone) to which $\mathrm{HO}^{*}$ is binding in an electrophilic addition reaction, and the spin state is conserved on the nitroxide moiety (Figure 7B). The PBN radical shows a characteristic ESR spectrum with three line groups. The larger separation (hyperfine splitting) arises from interaction of the unpaired electron with the nitrogen nuclear spin $(I=1)$. The small doublet splitting on each nitrogen line is caused by the nuclear spin $(I=1 / 2)$ of the hydrogen located on the adjacent carbon (Figure 7C). The line intensity (or signal integral) is used to quantify the PBN radical concentration as a measure of formed $\mathrm{HO}^{*}$ from a comparison with a standard. Usually, a stable nitroxide radical like TEMPOL (4-hydroxy-2,2,6,6tetramethylpiperidine1-oxyl) is recorded under identical conditions, or a spin counting software provided by some ESR instruments is applied.

In an ideal case, the spin-adduct $\mathrm{OH}-\mathrm{PBN}^{\bullet}$ should be sufficiently stable (at least for several minutes) for recording ESR spectra. As mentioned, many nitrone spin traps are not completely stable, a disadvantage demonstrated as an extreme example for the pronounced decay of $\mathrm{PBN}^{*}$ signals (Figure 7D). In this experiment, two solutions 


\section{Electron Spin Resonance (ESR) Spectroscopy}

$>$ Redox-Activated Spin Monitoring of $\mathrm{H}_{2} \mathrm{O}_{2}<$

A
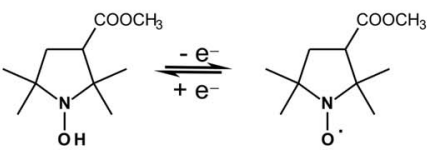

$\mathrm{CMH}$

$\mathrm{CM}^{\bullet}$

B

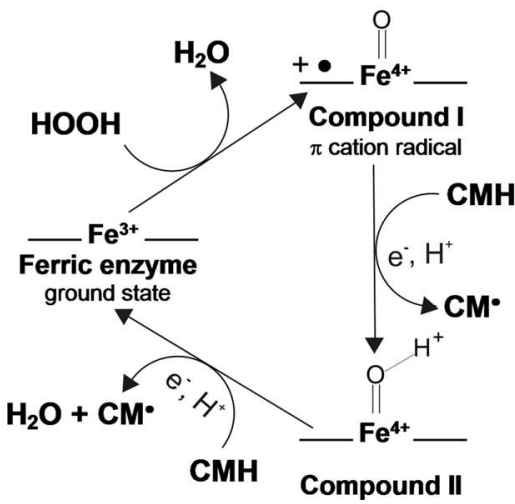

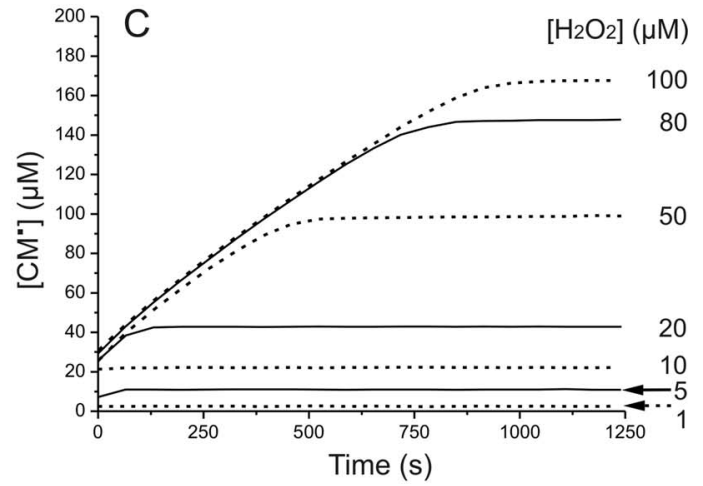

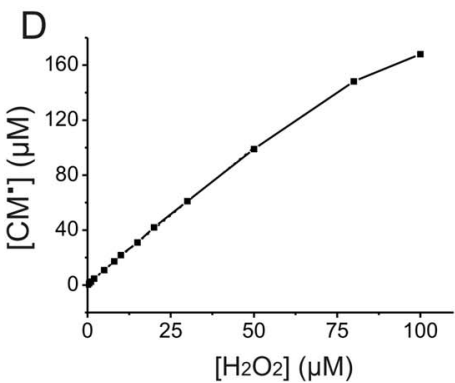

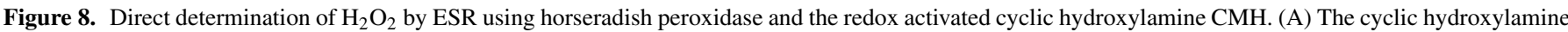

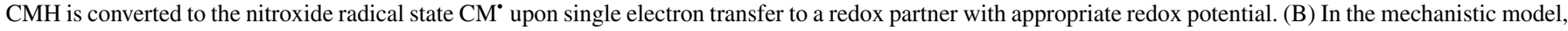

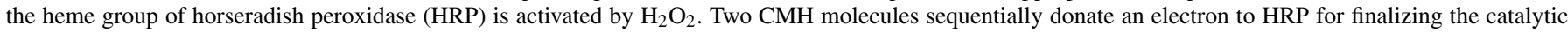

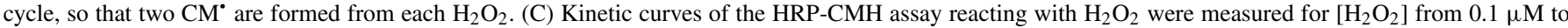

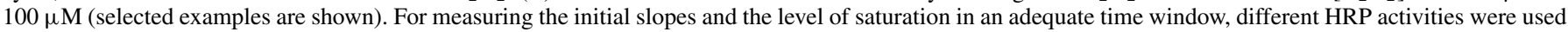

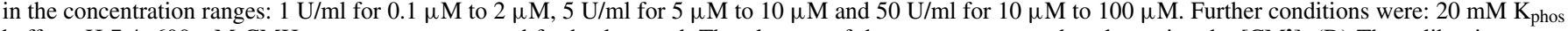

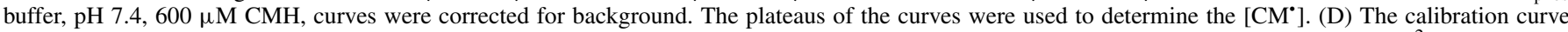

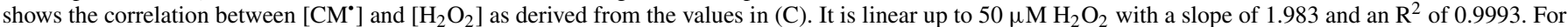
higher concentrations, the curve is slightly deviating.

(one containing $\mathrm{Fe}^{2+}$ and spin trap, the other $\mathrm{H}_{2} \mathrm{O}_{2}$ ) were rapidly mixed and directly injected into an ESR flat cell for measuring the time evolution of the first ESR signal (see Figure 7C). Trace " $a$ ", recorded for pure water, showed a very fast decay of the ESR signal ( $<0.5 \mathrm{~min}$ ), which was slowed down a little in phosphate buffer (trace " $b$ "). Trace " $c$ " was obtained for the related spin trap POBN ( $\alpha$-(4-pyridyl Noxide)-N-tert-butylnitrone) having a clearly longer lifetime for its $\mathrm{OH}$ adduct. The drastic decay of the $\mathrm{PBN}^{*}$ was abolished, when a small amount of ethanol $(3 \% \mathrm{v} / \mathrm{v})$ was added to the solution (Figure 7D, trace " $d$ "). The $\mathrm{HO}^{\circ}$ radicals now preferentially formed hydroxylethyl radicals which readily reacted with $\mathrm{PBN}$ to a very stable radical adduct.

The described example of the Fenton system highlights several essential parameters and conditions important for spin trap experiments: (i) Sensitivity of the spin trap has to be sufficiently high, i.e., the reaction kinetics needs to be fast enough to trap most of the radicals. (ii) The spin-adduct should be resistant to chemical decomposition and radical dismutation reactions and also insensitive to reductive or oxidative compounds present in the solution. (iii) Ideally, the spin trap is selective for a specific radical, like $\mathrm{HO}^{\circ}, \mathrm{O}_{2}^{-}$, carbon- or nitrogen-centered radicals, giving a characteristic ESR line pattern of the spin-adduct.

Similar as for $\mathrm{HO}^{*}$ radicals, the very short lifetime of the physiologically important superoxide radical ${ }^{\circ} \mathrm{O}_{2}{ }^{-}$which is the precursor of $\mathrm{H}_{2} \mathrm{O}_{2}$ (see Figure 1) requires to use spin traps for detection. $\mathrm{O}_{2}{ }^{-}$readily forms spin-adducts with cyclic nitrone traps with reasonable trapping rate constants up to $100 \mathrm{M}^{-1} \mathrm{~s}^{-1}$ and sufficiently long lifetimes for ESR detection in the range from 1 to $100 \mathrm{~min}$. Cyclic nitrone traps (e.g., DMPO, 5,5-dimethyl-1-pyrroline N-oxide, or DEPMPO, 5-diethoxyphosphoryl-5-methyl-1-pyrroline $\mathrm{N}$-oxide) show typical fingerprint patterns distinguishing superoxide and hydroxyl radical adducts. These properties of selected spin traps are adequate, if artificial in-vitro systems are investigated; for living sys- tems, problems may arise from intra- and/or extracellular metabolic pathways, which may interfere with the measurements.

In the past two decades, a variety of spin traps with optimized properties, particularly adduct-forming cyclic nitrones, and redoxactivated spin probes, like cyclic hydroxylamines have been synthesized to meet the requirements for optimal radical detection. Some of the research groups, using those spin traps and spin probes have commented on specificity and sensitivity, but also critically issued problems and made suggestions for reasonable precautions. ${ }^{56,410-419}$ A detailed list of available spin traps is regularly updated by the IUPAC (see https://goldbook.iupac.org/html/S/S05878.html).

$\mathrm{H}_{2} \mathrm{O}_{2}$ determinations in cell suspensions.-The Fenton reaction is certainly not suitable for detecting $\mathrm{H}_{2} \mathrm{O}_{2}$ in cell systems considering its low concentrations and the complications arising from free iron ions. During evolution of aerobic organisms, enzymes have emerged which degrade $\mathrm{H}_{2} \mathrm{O}_{2}$ (e.g., catalases) or utilize it in another type of biochemical reaction (e.g., peroxidases). The peroxidases use $\mathrm{H}_{2} \mathrm{O}_{2}$ and co-substrates, which deliver two electrons for reduction of $\mathrm{H}_{2} \mathrm{O}_{2}$ to water. Horseradish peroxidase (HRP) converts a variety of substrates, some of which yield colored or fluorescent products [e.g., ABTS (2,2'-azino-bis (3-ethylbenzothiazoline-6-sulphonic acid) or DAB (3,3'-diaminobenzidine)]. A standard fluorescence assay for measuring extracellular $\mathrm{H}_{2} \mathrm{O}_{2}$ produced by cells exploits the conversion of the non-fluorescent dye AmplexUltraRed, (AUR), a phenoxazine derivative, to fluorescent resorufin. ${ }^{420}$ The catalyzed reduction occurs via two sequential steps of one-electron oxidation of AUR forming two intermediate radicals which are dismutated to regain one AUR and form one colored, fluorescent resorufin. ${ }^{421}$ The appearance of radicals in the described catalytic peroxidase cycle, in principle, should allow using ESR for detection. Such an ESR approach was first accomplished by Aoyama et al. and was applied to increase sensitivity of immunoassays. ${ }^{422,423}$ Here, two molecules 
of the co-substrate p-acetamidophenol sequentially deliver two electrons to HRP, so that two phenoxy radicals are formed. Since the phenoxy radicals tend to dimerize, a fast reductive step is necessary which is carried out by redox-active cyclic hydroxylamines, like CPH (1-hydroxy-3-carboxyl-2,2,5,5-tetramethyl-pyrrolidine) or HTIO (1-hydroxy-2,2,5,5-tetramethyl-3-imidazoline-3-oxide). The typical structure of a cyclic hydroxylamine (here $\mathrm{CMH}$ : 1-hydroxy3-methoxycarbonyl-2,2,5,5-tetramethyl-pyrrolidine) is shown in Figure $8 \mathrm{~A}$. After deprotonation, the $\mathrm{N}-\mathrm{O}^{-}$unit easily delivers an electron to an acceptor having an adequate redox potential. The spin carrying nitroxide group is well protected by the bulky methyl groups so that it is quite stable in the presence of vitamin $\mathrm{C}$ or other reducing compounds working as anti-oxidants.

The HRP-ESR assay with p-acetamidophenol as co-substrate was also applied to directly determine $\mathrm{H}_{2} \mathrm{O}_{2}$ production in vascular smooth muscle cells expressing the NADPH oxidases NOX1 and NOX4. ${ }^{424}$ When $\mathrm{H}_{2} \mathrm{O}_{2}$ is measured, usually SOD is added to promote fast conversion of ${ }^{\circ} \mathrm{O}_{2}{ }^{-}$to $\mathrm{H}_{2} \mathrm{O}_{2}$ and to avoid complications of additional reactions with the spin probes. A few years ago, we have examined the biochemical reaction of a bacterial dioxygenase, in which a substrate transfers an electron to dioxygen in the active site, forming a shortlived radical-pair intermediate. Using $\mathrm{CMH}$ as a monitor for the radical pair, release of $\mathrm{H}_{2} \mathrm{O}_{2}$ was observed which was quantified with a modified HRP-ESR assay without p-acetamidophenol as co-substrate. ${ }^{425} \mathrm{It}$ was found that $\mathrm{CMH}$ directly operates as a co-substrate and electron donor for HRP, as shown in Figure $8 \mathrm{~B} . \mathrm{H}_{2} \mathrm{O}_{2}$ oxidizes the ferric ground state to compound I, which is reduced to compound II by $\mathrm{CMH}$ yielding the first $\mathrm{CM}^{*}$. Compound II is further reduced by a second $\mathrm{CMH}$ back to the ground state, whereby a second $\mathrm{CM}^{*}$ appears. Overall, two $\mathrm{CM}^{*}$ are formed for one consumed $\mathrm{H}_{2} \mathrm{O}_{2}$. To prove the stoichiometry and for calibration over a range of concentrations, defined amounts of $\mathrm{H}_{2} \mathrm{O}_{2}$ were titrated to a solution containing HRP and $\mathrm{CMH}$, and the reaction kinetics was recorded by ESR (Figure 8C). As expected from mechanistic considerations, the applied amount of $\mathrm{H}_{2} \mathrm{O}_{2}$ produced about twice the concentration of $\mathrm{CM}^{*}$. The calibration curve shown in Figure $8 \mathrm{D}$ is linear from $1 \mu \mathrm{M}$ up to $50 \mu \mathrm{M}\left[\mathrm{H}_{2} \mathrm{O}_{2}\right]$ with a slope of 1.98 close to the optimal value of 2 . Above $50 \mu \mathrm{M}$ of $\left[\mathrm{H}_{2} \mathrm{O}_{2}\right]$, the correlation deviates from a linear regression. The specifically modified HRP-ESR assay served to validate $\mathrm{H}_{2} \mathrm{O}_{2}$ determinations in the supernatant of primary human monocytes using an adapted Amplex UltraRed assay and electrochemical measurements with UMEs on single monocytes. For all three techniques, similar results were obtained concerning $\mathrm{H}_{2} \mathrm{O}_{2}$ production and degradation/elimination dynamics by the monocytes. ${ }^{122}$ Since radicals are monitored in this assay, careful control experiments have to be performed to recognize unwanted side reactions and artefacts.

In conclusion, the HRP-ESR assay represents an additional tool for quantitative measurement of $\mathrm{H}_{2} \mathrm{O}_{2}$. It is limited to detect $\mathrm{H}_{2} \mathrm{O}_{2}$ in the extracellular fluid of cell suspensions at a reliable concentration range from 1 to at least $50 \mu \mathrm{M}$. Measurements can be calibrated very precisely in that range. Another advantage in comparison to fluorescencebased technologies is that EPR can be used in solutions which are not sufficiently transparent for fluorescent light.

Spin trapping in cellular systems.-Spin traps have not only been applied in artificial sytems but also in biological and medical studies in vitro and in vivo. ${ }^{426-435}$ Due to the complex composition of solutions and low radical production in such experiments, careful control and calibration experiments need to be performed for a quantitative interpretation of spin trapping ESR measurements. Particularly, when working with cells in physiological buffer solutions, Fenton type reactions often have to be controlled by using metal chelators to avoid strong background signals and artefacts.

For the detection of resting and stimulated extracellular ${ }^{\circ} \mathrm{O}_{2}{ }^{-}$ production by living RAW 264.7 macrophages, Abbas et al. compared "classical" and newly developed nitrone spin traps. Conclusively, the researchers found that with the methyl- $\beta$ cyclodextrin-bound spin trap, called CD-DIPPMPO (6-monodeoxy-6mono-4-[(5diisopropoxyphosphoryl-5-methyl-1-pyrroline- $N$-oxide)- ethylenecarbamoyl-(2,3-di- $O$-methyl)hexakis-(2,3,6-tri- $O$-methyl)]$\beta$-cyclodextrin), ${ }^{\circ} \mathrm{O}_{2}{ }^{-}$could be determined rather specifically (without hydroxyl adduct) and with high stability using ESR. ${ }^{436}$

Because of their reducing properties, the hydroxylamines $\mathrm{CPH}$ and $\mathrm{CMH}$ (and related compounds with differing membrane permeabilities) were also successfully employed to monitor and quantify formation of ${ }^{\circ} \mathrm{O}_{2}{ }^{-}$in various cell systems, such as lymphoblasts, monocytes, endothelial cells or in isolated mitochondria. After reduction of ${ }^{\circ} \mathrm{O}_{2}{ }^{-}$ to $\mathrm{H}_{2} \mathrm{O}_{2}$ the formation of the nitroxide radical signal was monitored over time and was quantified. ${ }^{11,427,429,437,438}$ These spin probes are inert to reaction with $\mathrm{H}_{2} \mathrm{O}_{2}$, and the nitroxide is sufficiently stable in the presence of $\mathrm{H}_{2} \mathrm{O}_{2}$ or compounds of physiological buffer solutions.

There is a continuous development of new spin probes and spin traps with optimized specificity, sensitivity and stability for ESR work on cell systems and tissues. Because of the toxicity of most spin probes, they are not applicable for human in-vivo systems.

In-vivo ESR.-The "ultimate goal" of monitoring reactive oxygen species, like ${ }^{\circ} \mathrm{O}_{2}{ }^{-}$or $\mathrm{H}_{2} \mathrm{O}_{2}$, or lipid and protein radicals would be their determination and quantification right at the place of formation and function within an organism (in vivo) or an explanted organ (in situ). To additionally follow spatial and temporal distribution of such species and their metabolism would perfect the measurements. Since more than 40 years, research groups are applying "in vivo ESR", to meet these claims. Substantial information including critical discussions about this specialized ESR technique can be obtained from textbooks and diverse review articles. ${ }^{43-443}$ For in-vivo ESR, the relevant objects of interest are again radicals, like ${ }^{\circ} \mathrm{O}_{2}{ }^{-}$or $\mathrm{HO}^{*}$ or other types emerging from physiological and/or pathological metabolism within an organ or an animal. Because of the low steady state concentrations of such transient radicals, they usually are trapped by a suitable spin probe (e.g., DMPO; POBN). Here, the spin traps are administered to an animal, which is then subjected to a pre-defined treatment depending on the experimental issue. Both, in-vivo and ex-vivo techniques are then applied.

For ex-vivo measurements, body fluids and/or tissues are extracted, from which the radical spin-adducts are then determined. Standard ESR spectrometers, usually operating at $9 \mathrm{GHz}$ microwave frequency can be applied. ${ }^{444}$ Alternatively, nitroxide radical spin probes are administered, and their decay kinetics and spectral properties are determined. With specially designed spin probes, relevant physiological parameters, such as $\mathrm{pH}$, partial oxygen pressure or redox states become accessible in tissue. ${ }^{445,446}$

In order to use spin traps or functional spin probes for in-vivo measurements on animals (usually mice or rats) or on parts of them, it is mandatory to reduce the frequency to $2 \mathrm{GHz}$ or as low as $250 \mathrm{MHz}$ for whole-body measurements. Higher frequencies cannot penetrate such large samples sufficiently because of the strong absorption of the electromagnetic radiation by water. For the low frequencies and large objects, special resonators, like loop gap resonators and surface coils have been designed to minimize dielectric losses and to compensate for the reduced sensitivity at low frequencies. ${ }^{447}$ This approach also offers the possibility to measure the concentration and location of spin probes in an animal body when applying magnetic field gradients in one or more dimensions (ESR imaging) similar to the proton-resonance based nuclear magnetic resonance imaging (MRI). ${ }^{447}$ Relevant advances in improving the spatio-temporal resolution and sensitivity of this technique have been described and summarized recently. ${ }^{448-451}$

A variety of aspects have to be considered when using in-vivo ESR: (i) maintenance of physiological conditions, like $\mathrm{pH}$, temperature and oxygen supply during the on-going measurement, (ii) choice of a suitable spin trap, (iii) fast acquisition of data to monitor situations in real-time, (iv) improvement of signal-to-noise ratio of the data, $(v)$ clearly defined ("simple") ESR spectra or particular aspects of the spectra, like the amplitude, and (vi) reasonable compromise between spatial resolution and signal yield. To meet all these challenges and enable reliable in-vivo ESR measurements even for very sophisticated experimental requirements, companies have developed and specifically optimized hard- and soft-ware of ESR devices. 
In-vivo ESR is increasingly applied in the field of life sciences, since it enables observations not covered by other techniques. Investigations on animals have been undertaken routinely, however, special carefulness and equipment are needed, when human subjects are going to be inspected within clinical studies. Since more than two decades, scientists are absolutely convinced of the fact that redox processes, involving species like ${ }^{\circ} \mathrm{O}_{2}{ }^{-}$and $\mathrm{H}_{2} \mathrm{O}_{2}$, are of crucial importance for patho/physiological cellular metabolism. In this context, in-vivo ESR proved to support deeper insight into the underlying mechanisms. ${ }^{439,446,452-461}$

Beyond ESR spin trapping: immuno-spin trapping (IST).-The original ESR-based spin-trapping technique was decisively expanded by an approach combining spin trapping with antigen:antibody interactions, resulting in the so-called "immuno-spin trapping" (IST). A spin trap moiety (usually DMPO, 5,5-dimethyl-1-pyrroline N-oxide) represents the antigen which, however, is not found in nature. The corresponding antibody (anti-DMPO) is derived from the antiserum of an animal which has been exposed to the modified antigen, DMPOhapten, linked to a protein carrier. The nitrone spin trap DMPO is added to the sample containing cellular proteins or organelles, intact cells or tissue. With radicals present in the samples, DMPO spinadducts are forming with reasonably fast kinetics. In a cellular environment, the lifetime of the radical spin-adducts is limited to seconds or minutes, since they can be converted to stable non-radical DMPOnitrone by cellular oxidizing equivalents or by reduction to a hydroxylamine form. The subsequently applied nitrone antibody (anti-DMPO) specifically recognizes the spin-adduct-nitrone, thereby indicating the location of the initial radical. With the toolbox of immunoassays, like Western blot, ELISA (enzyme-linked immunosorbent assay) and immunohistochemistry, the location, distribution and amount of radicals in defined cell conditions can be analyzed with an unmatched sensitivity and selectivity. The pioneering work for the development of IST was performed by the research group of Mason et al. who also contributed to various applications of the IST technique [for a review see Ref. 462].

In principle, all macromolecular radicals, derived from e.g., proteins or DNA, can be measured very specifically with IST. ${ }^{451,462-469}$

A novel and intriguing extension of the IST methodology arose from a combination with molecular magnetic resonance imaging (mMRI) for in-vivo and in-situ localization of radical sites in preclinical studies. In this case, chelated paramagnetic gadolinium (Gd), a well-known MRI contrast agent, is linked to a modified anti-DMPO. After binding to a radical site marked by DMPO-nitrone, the Gdadduct affects signal intensity and relaxation times of proton resonances around this site in MRI experiments. From these parameters, the initial location and radical concentration can be directly determined. For comparison, these results can be aligned to ex-vivo fluorescent experiments on respective samples. ${ }^{451,464}$

Not only advantages, but also challenges and pitfalls of this technique have to be considered. ${ }^{465}$ Major issues might be the relatively low sensitivity for very low radical concentrations, a possible interference with the metabolism of the sample, the lack of temporal resolution and of absolute quantification. Up to now, IST has been applied in a variety of in-vitro and in-vivo studies, including animal disease models, in order to elucidate the impact of radical formation under physiological and pathological conditions. ${ }^{451,464,470-472}$

Instrumentation for ESR spectroscopy.-ESR spectrometers used in research and in clinical applications are rather expensive and complex instruments requiring experienced personnel for operation and evaluation of experiments. Currently, high-performance and automatized desktop ESR spectrometers become available, which can be operated following validated protocols for monitoring radicals in systems of living cells. If more advanced ESR technologies, like invivo ESR is employed in tissues, whole animals or on human subjects, an even broader range of professionalism is required. This is also the case, if spin traps are being used in conventional and in-vivo ESR as well as in immuno-spin trapping.
Sophisticated software provided by manufacturers is of great help to automatically analyze the quantity and composition of measured ESR line pattern of a certain spin probe retrieving essential parameters from a data base. Hence, classical and advanced ESR spectroscopy provide valuable tools for detecting and quantifying physiologically relevant reactive oxygen species, not only in research but also increasingly in clinical applications.

\section{Conclusive Evaluations of Electrochemical and ESR Spectroscopic $\mathrm{H}_{2} \mathrm{O}_{2}$ (and ${ }^{\cdot} \mathrm{O}_{2}^{-}$) Determinations}

As outlined in parts 2 and 3, multiple technologies have been developed to determine and, if possible, to exactly quantify $\mathrm{H}_{2} \mathrm{O}_{2}$ from living cells, excised small organs or organelles and from whole animals. Table I gives a comprehensive overview of the main technological tools described. To optimize measurements and adapt them to particular demands, electrode systems of various types, redox mediators and complicated protocols - in the case of electrochemical determinations - are employed (compare Figures 2-6). Depending on the experimental conditions and the size of the electrode, $\mathrm{H}_{2} \mathrm{O}_{2}$ production (and clearance) by cells in suspension and outside of single cells (see Figure 5) can be followed with remarkable temporal resolution of up to $1 \mathrm{kHz}$. Combined extra- and intracellular $\mathrm{H}_{2} \mathrm{O}_{2}$ measurements have also been reported. Due to calibration of the system, real-time $\mathrm{H}_{2} \mathrm{O}_{2}$ quantification is possible for each value of measured current. By following reaction dynamics over time, quantitative insight into patho-/physiological signaling pathways is provided which, so far, is unavailable by other methods. Using SECM with a UME at single cells, spatial resolution can be in the order of micro meter or below (see Figure 6), depending on the diameter of the electrode tip. Detection limits for $\mathrm{H}_{2} \mathrm{O}_{2}$, as determined with electrochemical methodology, span the low nano- up to millimolar concentration range and thus perfectly cover physiological values.

ESR spectroscopic $\mathrm{H}_{2} \mathrm{O}_{2}$ measurements, e.g., in the extracellular fluid of cell suspensions, require a sophisticated experimental design and the aid of spin probes and other chemicals, since $\mathrm{H}_{2} \mathrm{O}_{2}$ is a non-radical ROS and cannot be measured directly (see Figures 7 and 8). Concentrations in the low micromolar range can be reliably monitored over a time span of a few hours. Oxygen consumption in an air-tightly sealed system is the main time-limiting factor. By using gas permeable polymer capillaries, the oxygen limitation can be overcome.

Extracellular electrochemical as well as ESR spectroscopic $\mathrm{H}_{2} \mathrm{O}_{2}$ determinations are non-invasive and, if carefully conducted at physiological conditions, may only slightly interfere with the ROS metabolism of the cells. In the contrary, for intracellular $\mathrm{H}_{2} \mathrm{O}_{2}$ measurements, either using nanodes (which have to be impaled into the cell) or transfecting genetically-encoded fluorescent dyes (like roGFP or $\mathrm{HyPer}$ ), it cannot be excluded that already basal $\mathrm{H}_{2} \mathrm{O}_{2}$ levels are elevated due to manipulative stress. Generating transgenic mice which stably express a redox-sensitive fluorescent dye can avoid the manipulative stress. $^{78}$

As detailed in Table I for the described electrochemical sensors and for ESR spectroscopy, all methods to determine $\mathrm{H}_{2} \mathrm{O}_{2}$ face limitations which are summarized within the present paragraph more generally.

Construction of working electrodes as efficient sensors for reliable, specific, sensitive and long-time measurements of $\mathrm{H}_{2} \mathrm{O}_{2}$ may include complicated, time-consuming and expensive procedures. Electrodes or electrode systems (arrays) have to be of a high standard that allows comparison of day-to-day experimental data obtained with different individual sensors of the same type. Further demanding operations are maintenance and eventual reconstitution of the sensors after application. Sophisticated modifications of electrode tips or usage of redox mediators, although highly efficient for in-vitro experiments, may be adverse for $\mathrm{H}_{2} \mathrm{O}_{2}$ measurements at living cells, when utilized materials interfere with cellular metabolism or are even toxic. The absence of oxygen, low $\mathrm{pH}(\leq 7)$ or temperature may be optimal conditions for electrochemical $\mathrm{H}_{2} \mathrm{O}_{2}$ measurements in the test-tube, are inappropriate, however, for living cells. 
When the non-radical $\mathrm{H}_{2} \mathrm{O}_{2}$ is (indirectly) monitored with ESR spectroscopy, supporting (non-physiological) chemicals have to be added to the reaction tube containing the cell suspension. Long-time ESR measurements may suffer from oxygen exhaustion. Recognizing and handling of measuring artefacts as well as calibrations may be challenging. Furthermore, the monitored radicals are accumulating in irreversible reactions and therefore cannot reflect dynamic changes of involved cellular metabolic processes (e.g., production and degradation of $\mathrm{H}_{2} \mathrm{O}_{2}$ ). To display reaction dynamics, single timepoint determinations (with only limited time resolution) have to be performed.

With advanced technologies, like immuno-spin trapping or in-vivo ESR, in principle, all kinds of radicals can be monitored. Because of the short lifetimes they have to be targeted by spin traps, the choice of which depends on the radical and the specimen to be investigated. For experimentation and scientific conclusions deducted from these experiments professional expertise is required.

\section{Future Directions}

The potentially greatest challenges in redox cell biology are timeresolved, quantitative (absolute and not relative) $\mathrm{H}_{2} \mathrm{O}_{2}$ measurements inside and outside of single cells under physiological conditions. Fluorescence measurements are well-suited for compartmentalized ROS in single cells, thus giving excellent spatial resolution, but they have major disadvantages: (i) their dynamic range is usually only one order of magnitude; (ii) sensitivity (and selectivity) are in many cases limited; and (iii) absolute quantification of the $\left[\mathrm{H}_{2} \mathrm{O}_{2}\right]$ is not possible to date. To overcome these and other limitations, fluorescence measurements can be combined with electrochemical and/or ESR measurements. As for ${ }^{-} \mathrm{O}_{2}{ }^{-}$, ESR can serve as a "gold standard" for $\mathrm{H}_{2} \mathrm{O}_{2}$ determinations, however only for cell suspensions and not for single cells. ESR is a quantitative technology with reasonable temporal resolution, selectivity and sensitivity, and should thus be used routinely to test the results of single cell fluorescence-based data. For electrochemical approaches, one can certainly go one step further. The technology is highly sensitive (even higher than ESR) and selective for $\mathrm{H}_{2} \mathrm{O}_{2}$, and it is applicable to single cells, as elaborately described in Electrochemical Determination and Quantification of $\mathrm{H}_{2} \mathrm{O}_{2}$ section of the present review. Experiments by Salamifar et al. ${ }^{390}$ have shown that it is feasible to combine fluorescence-based and electrochemical measurements for $\mathrm{H}_{2} \mathrm{O}_{2}$ on the same sample, e.g., a single living cell. The group of Xin et al. ${ }^{473}$ even broadened the methological spectrum by combining electrochemical and fluorescence measurements with ESR to monitor $\mathrm{H}_{2} \mathrm{O}_{2}$ dynamics from $\mathrm{HeLa}$ cells. Using such elaborated combinations, mutual validation of the approaches as well as quantification of the respective $\mathrm{H}_{2} \mathrm{O}_{2}$ signals should be possible. Time-resolved parallel $\mathrm{H}_{2} \mathrm{O}_{2}$ measurements inside and outside of the same cell could thus inform about dynamics in spatial and temporal distribution of $\mathrm{H}_{2} \mathrm{O}_{2}$, and how these dynamics may vary under different experimental conditions. Furthermore, it might be possible to test the impact on cellular ROS levels of pre-loading a cell with a fluorescence dye or transfecting it with a vector for intracellular expression of a ROS sensor (like HyPer). Information about those cells are lacking to date just as they lack for stably transfected cells with a ROS sensor, like roGFP. Although it is of general agreement that ROS metabolism of transgenic compared to wild-type animals is not altered, however, this assumption is very risky and should be reconsidered as fast as possible. Now we have tools at hand to check this carefully.

\section{Annotations to Methods and Ethics of Experimentation}

Simulations of the voltammograms shown in Figures 2, 3 and 4, were performed with the MATHCAD 14 program. Calculations for the voltammograms depicted in Figure 2B, are based on the mathematical model of kinetically-controlled diffusional redox reaction, explained by Bieniasz. ${ }^{474}$ For the voltammograms presented in Figures $3 \mathrm{~B}$ and $4 \mathrm{~B}$, calculations were derived from equations detailed by Gulaboski et al. ${ }^{216}$
Materials and methods applied for the original electrochemical experiments shown in Figures 5 and 6 are described at full length in the Materials and Methods section of the article by Bozem et al. ${ }^{122}$ The experiments were carried out by M. Bozem with primary monocytes from anonymized (male/female) healthy human blood donors. Studies have been authorized by the local ethic committee in the declaration from April 16 ${ }^{\text {th }}, 2015$ (84/15; Prof. Dr. Rettig-Stürmer). The experiments have not been published before.

\section{Acknowledgments}

We are grateful to Carmen Hässig for preparation of the primary human monocytes. In addition, we thank Christian Heinemann, Ivan Bogeski, and Katerina Stankoska for their professional help in the field of electrochemistry. Ewa J. Slowik and Nhat Nguyen Bui are thankfully acknowledged for the ESR spectroscopic experiments. This work has been funded by the Deutsche Forschungsgemeinschaft (SFB 894, SFB 1027); and the Bundesministerium für Bildung und Forschung (ZIM KF2152005AK1). V.M. acknowledges support by the NATO Science for Peace and Security Programme (grant SPS G5550).

\section{ORCID}

Monika Bozem (D) https://orcid.org/0000-0002-1419-3099

\section{References}

1. Y. M. Janssen-Heininger, B. T. Mossman, N. H. Heintz, H. J. Forman, B. Kalyanaraman, T. Finkel, J. S. Stamler, S. G. Rhee, and A. van der Vliet, Free radical biology \& medicine, $\mathbf{4 5}, 1$ (2008).

2. E. A. Veal, A. M. Day, and B. A. Morgan, Molecular cell, 26, 1 (2007).

3. C. Lennicke, J. Rahn, R. Lichtenfels, L. A. Wessjohann, and B. Seliger, Cell communication and signaling: CCS, 13, 39 (2015).

4. M. E. Preston, D. Jensen, I. Janssen, and J. T. Fisher, American journal of physiology. Regulatory, integrative and comparative physiology, 296, R722 (2009).

5. I. S. Ambudkar and S. Muallem, Cell calcium, 60, 51 (2016).

6. B. D'Autreaux and M. B. Toledano, Nature reviews. Molecular cell biology, 8, 813 (2007).

7. I. Bogeski, R. Kappl, C. Kummerow, R. Gulaboski, M. Hoth, and B. A. Niemeyer, Cell calcium, 50, 407 (2011)

8. E. C. Schwarz, B. Qu, and M. Hoth, Biochimica et biophysica acta, 1833, 1603 (2013).

9. M. Hoth, Biochimica et biophysica acta, 1863, 1408 (2016).

10. A. Quintana, M. Pasche, C. Junker, D. Al-Ansary, H. Rieger, C. Kummerow, L. Nunez, C. Villalobos, P. Meraner, U. Becherer, J. Rettig, B. A. Niemeyer, and M. Hoth, The EMBO journal, 30, 3895 (2011).

11. S. Saul, C. S. Gibhardt, B. Schmidt, A. Lis, B. Pasieka, D. Conrad, P. Jung, R. Gaupp, B. Wonnenberg, E. Diler, H. Stanisz, T. Vogt, E. C. Schwarz, M. Bischoff, M. Herrmann, T. Tschernig, R. Kappl, H. Rieger, B. A. Niemeyer, and I. Bogeski, Science signaling, 9, ra26 (2016)

12. S. Parvez, M. J. C. Long, J. R. Poganik, and Y. Aye, Chemical reviews, 118, 8798 (2018).

13. C. C. Winterbourn, Antioxidants \& redox signaling, (2017).

14. D. B. Zorov, M. Juhaszova, and S. J. Sollott, Biochimica et biophysica acta, 1757, 509 (2006).

15. D. I. Brown and K. K. Griendling, Free radical biology \& medicine, 47, 1239 (2009).

16. M. Ushio-Fukai, Science's STKE: signal transduction knowledge environment, 2006, re8 (2006).

17. R. P. Brandes, N. Weissmann, and K. Schroder, Free radical biology \& medicine, 76C, 208 (2014)

18. M. D. Brand, Free radical biology \& medicine, 100, 14 (2016).

19. P. R. Angelova and A. Y. Abramov, Free radical biology \& medicine, 100, 81 (2016).

20. C. L. Quinlan, R. L. Goncalves, M. Hey-Mogensen, N. Yadava, V. I. Bunik, and M. D. Brand, The Journal of biological chemistry, 289, 8312 (2014).

21. L. Slade, J. Chalker, N. Kuksal, A. Young, D. Gardiner, and R. J. Mailloux, Biochimica et biophysica acta, 1861, 1960 (2017).

22. H. Sies, Redox biology, 11, 613 (2017).

23. M. B. Iversen, R. H. Gottfredsen, U. G. Larsen, J. J. Enghild, J. Praetorius, N. Borregaard, and S. V. Petersen, Free radical biology \& medicine, 97, 478 (2016).

24. G. R. Buettner, Anti-cancer agents in medicinal chemistry, 11, 341 (2011).

25. M. Che, R. Wang, X. Li, H. Y. Wang, and X. F. Zheng, Drug discovery today, 21, 143 (2016).

26. C. C. Winterbourn, Methods in enzymology, 528, 3 (2013).

27. E. Cadenas and L. Packer, Methods in enzymology, 528, xv (2013).

28. L. M. Randall, G. Ferrer-Sueta, and A. Denicola, Methods in enzymology, 527, 41 (2013).

29. M. Schieber and N. S. Chandel, Current biology: CB, 24, R453 (2014)

30. D. R. Dreyer, S. Park, C. W. Bielawski, and R. S. Ruoff, Chemical Society reviews, 39, 228 (2010). 
31. F. Antunes and P. M. Brito, Redox biology, 13, 1 (2017).

32. S. Stöcker, M. Maurer, T. Ruppert, and T. P. Dick, Nature chemical biology, 14, 148 (2018).

33. I. Bogeski, C. Kummerow, D. Al-Ansary, E. C. Schwarz, R. Koehler, D. Kozai, N. Takahashi, C. Peinelt, D. Griesemer, M. Bozem, Y. Mori, M. Hoth, and B. A. Niemeyer, Science signaling, 3, ra24 (2010).

34. H. S. Marinho, C. Real, L. Cyrne, H. Soares, and F. Antunes, Redox biology, 2, 535 (2014).

35. F. Vatansever, D. M. W. C., P. Avci, V. D., M. Sadasivam, A. Gupta, R. Chandran, M. Karimi, N. A. Parizotto, R. Yin, G. P. Tegos, and M. R. Hamblin, FEMS microbiology reviews, 37, 955 (2013).

36. S. Dupre-Crochet, M. Erard, and O. Nubetae, Journal of leukocyte biology, 94, 657 (2013).

37. G. J. Burton and E. Jauniaux, Best practice \& research. Clinical obstetrics \& gynaecology, 25, 287 (2011).

38. T. Finkel, Current Opinion in Cell Biology, 15, 247 (2003).

39. J. R. Burgoyne, S. Oka, N. Ale-Agha, and P. Eaton, Antioxidants \& redox signaling, 18, 1042 (2013)

40. G. Bauer, Anticancer research, 34, 1467 (2014).

41. R. K. Gupta, A. K. Patel, N. Shah, A. K. Chaudhary, U. K. Jha, U. C. Yadav, P. K. Gupta, and U. Pakuwal, Asian Pacific journal of cancer prevention: APJCP, 15, 4405 (2014)

42. B. Groitl and U. Jakob, Biochimica et biophysica acta, 1844, 1335 (2014).

43. S. Garcia-Santamarina, S. Boronat, and E. Hidalgo, Biochemistry, 53 (2014).

44. R. L. van Montfort, M. Congreve, D. Tisi, R. Carr, and H. Jhoti, Nature, 423, 773 (2003).

45. I. Bogeski, M. Bozem, L. Sternfeld, H. W. Hofer, and I. Schulz, Cell calcium, 40, 1 (2006).

46. A. Kuban-Jankowska, M. Gorska, L. Jaremko, M. Jaremko, J. A. Tuszynski, and M. Wozniak, Biometals: an international journal on the role of metal ions in biology, biochemistry, and medicine, 28, 975 (2015).

47. P. M. Brito and F. Antunes, Frontiers in chemistry, 2, 82 (2014).

48. S. G. Rhee, H. A. Woo, and D. Kang, Antioxidants \& redox signaling, 28, 537 (2018).

49. L. Flohe, Biochimica et biophysica acta, 1830, 3139 (2013).

50. S. Biswas, A. S. Chida, and I. Rahman, Biochemical pharmacology, 71, 551 (2006).

51. A. J. Bard, R. Parsons, and J. Jordan, Standard Potentials in Aqueous Solution, Taylor \& Francis (1985).

52. C. Jacob and P. G. Winyard, Redox Signaling and Regulation in Biology and Medicine, Wiley (2009).

53. J. A. Imlay, Annual review of microbiology, 57, 395 (2003).

54. C. W. Jones, Applications of Hydrogen Peroxide and Derivatives, Royal Society of Chemistry (1999).

55. F. Cataldo, NEW FRONT. CHEM, 23, 99 (2014).

56. B. Halliwell and J. M. C. Gutteridge, Free Radicals in Biology and Medicine, Oxford University Press (2015).

57. M. Rac, M. Krupka, S. Binder, M. Sedlarova, Z. Matuskova, M. Raska, and P. Pospisil, PloS one, 10, e0116958 (2015).

58. M. Valko, K. Jomova, C. J. Rhodes, K. Kuca, and K. Musilek, Archives of toxicology, 90, 1 (2016)

59. W. Freinbichler, M. A. Colivicchi, C. Stefanini, L. Bianchi, C. Ballini, B. Misini, P. Weinberger, W. Linert, D. Vareslija, K. F. Tipton, and L. Della Corte, Cellula and molecular life sciences: CMLS, 68, 2067 (2011).

60. M. Valko, D. Leibfritz, J. Moncol, M. T. Cronin, M. Mazur, and J. Telser, The international journal of biochemistry \& cell biology, 39, 44 (2007).

61. K. Brieger, S. Schiavone, F. J. Miller Jr., and K. H. Krause, Swiss medical weekly, 142, w13659 (2012)

62. A. Rao and B. Balachandran, Nutr. Neurosci., 5, 291 (2002)

63. S. Rapino, R. Marcu, A. Bigi, A. Soldà, M. Marcaccio, F. Paolucci, P. G. Pelicci, and M. Giorgio, Electrochimica Acta, 179, 65 (2015).

64. J. P. Bolanos, E. Cadenas, M. R. Duchen, M. B. Hampton, G. E. Mann, and M. P. Murphy, Free radical biology \& medicine, 100, 1 (2016)

65. J. F. Woolley, J. Stanicka, and T. G. Cotter, Trends in biochemical sciences, 38, 556 (2013).

66. G. J. Maghzal, K. H. Krause, R. Stocker, and V. Jaquet, Free radical biology \& medicine, 53, 1903 (2012).

67. B. K. Huang and H. D. Sikes, Redox biology, 2, 955 (2014).

68. S. Pouvreau, Antioxidants \& redox signaling, 25, 517 (2016).

69. H.-S. Wang, TrAC Trends in Analytical Chemistry, 85, 181 (2016).

70. A. Gomes, E. Fernandes, and J. L. Lima, Journal of biochemical and biophysical methods, $\mathbf{6 5}, 45$ (2005).

71. H. Guo, H. Aleyasin, B. C. Dickinson, R. E. Haskew-Layton, and R. R. Ratan, Cell Biosci, 4, 64 (2014).

72. B. Morgan, K. Van Laer, T. N. Owusu, D. Ezerina, D. Pastor-Flores, P. S. Amponsah, A. Tursch, and T. P. Dick, Nature chemical biology, 12, 437 (2016)

73. D. S. Bilan and V. V. Belousov, Antioxidants \& redox signaling, 24, 731 (2016).

74. S. C. Albrecht, A. G. Barata, J. Grosshans, A. A. Teleman, and T. P. Dick, Cell metabolism, 14, 819 (2011).

75. S. Pouvreau, Biotechnology journal, 9, 282 (2014).

76. K. A. Lukyanov and V. V. Belousov, Biochimica et biophysica acta, 1840, 745 (2014).

77. M. Schwarzlander, T. P. Dick, A. J. Meyer, and B. Morgan, Antioxidants \& redox signaling, 24, 680 (2016)

78. L. P. Prates-Roma, M. Deponte, J. Riemer, and B. Morgan, Antioxidants \& redox signaling, (2018).

79. D. S. Bilan and V. V. Belousov, Free radical biology \& medicine, 109, 167 (2017).
80. P. Wardman, Free radical biology \& medicine, 43, 995 (2007).

81. C. C. Winterbourn, Biochimica et biophysica acta, 1840, 730 (2014).

82. E. A. Specht, E. Braselmann, and A. E. Palmer, Annual review of physiology, 79, 93 (2017)

83. M. Yazdani, Toxicology in vitro: an international journal published in association with BIBRA, 30, 578 (2015)

84. K. Debowska, D. Debski, M. Hardy, M. Jakubowska, B. Kalyanaraman, A. Marcinek, R. Michalski, B. Michalowski, O. Ouari, A. Sikora, R. Smulik, and J. Zielonka, Pharmacological reports: PR, 67, 756 (2015).

85. D. Ganini, F. Leinisch, A. Kumar, J. Jiang, E. J. Tokar, C. C. Malone, R. M. Petrovich, and R. P. Mason, Redox biology, 12, 462 (2017).

86. S. Douthwright and G. Sluder, Journal of cellular physiology, 232, 2461 (2017).

87. A. P. Wojtovich and T. H. Foster, Redox biology, 2, 368 (2014).

88. A. J. Trewin, B. J. Berry, A. Y. Wei, L. L. Bahr, T. H. Foster, and A. P. Wojtovich, Free radical biology \& medicine, 128, 157 (2018).

89. A. Ettinger and T. Wittmann, Methods in cell biology, 123, 77 (2014)

90. V. Magidson and A. Khodjakov, Methods in cell biology, 114, 545 (2013).

91. B. Kalyanaraman and J. Zielonka, Redox biology, 12, 755 (2017).

92. T. Xiao, F. Wu, J. Hao, M. Zhang, P. Yu, and L. Mao, Anal Chem, 89, 300 (2017)

93. P. Bollella, G. Fusco, C. Tortolini, G. Sanzo, G. Favero, L. Gorton, and R. Antiochia, Biosensors \& bioelectronics, 89, 152 (2017).

94. J. N. Tiwari, V. Vij, K. C. Kemp, and K. S. Kim, ACS nano, 10, 46 (2016).

95. C. Yang, M. E. Denno, P. Pyakurel, and B. J. Venton, Analytica chimica acta, 887, 17 (2015)

96. A. Yakoh, C. Pinyorospathum, W. Siangproh, and O. Chailapakul, Sensors, 15, 21427 (2015).

97. B. J. Privett, J. H. Shin, and M. H. Schoenfisch, Anal Chem, 82, 4723 (2010).

98. D. Grieshaber, R. MacKenzie, J. Voros, and E. Reimhult, Sensors, 8, 1400 (2008).

99. S. H. Chen, R. Yuan, Y. Q. Chai, and F. X. Hu, Microchimica Acta, 180, 15 (2013)

100. Z. Li, Y. Yu, Z. Li, T. Wu, and J. Yin, Analyt Meth, (2015).

101. R. Renneberg and F. Lisdat, (2008).

102. S. A. Lim and M. U. Ahmed, RSC Adv., 6, 24995 (2016).

103. C. G. Zoski, Handbook of Electrochemistry, Elsevier (2007).

104. R. G. Compton and C. E. Banks, Understanding Voltammetry, Imperial College Press (2011).

105. A. J. Bard and R. W. Murray, Proceedings of the National Academy of Sciences of the United States of America, 109, 11484 (2012).

106. A. J. Bard and L. R. Faulkner, Electrochemical Methods: Fundamentals and Applications, Wiley (2000).

107. D. S. Schrock and J. E. Baur, Anal Chem, 79, 7053 (2007).

108. A. L. Sanford, S. W. Morton, K. L. Whitehouse, H. M. Oara, L. Z. Lugo-Morales, J. G. Roberts, and L. A. Sombers, Anal Chem, 82, 5205 (2010).

109. J. A. Koch, M. B. Baur, E. L. Woodall, and J. E. Baur, Anal Chem, 84, 9537 (2012)

110. M. Spanos, J. Gras-Najjar, J. M. Letchworth, A. L. Sanford, J. V. Toups, and L. A. Sombers, ACS chemical neuroscience, 4, 782 (2013).

111. J. G. Roberts, J. V. Toups, E. Eyualem, G. S. McCarty, and L. A. Sombers, Anal Chem, 85, 11568 (2013)

112. J. G. Roberts, M. A. Voinov, A. C. Schmidt, T. I. Smirnova, and L. A. Sombers, Journal of the American Chemical Society, 138, 2516 (2016).

113. L. R. Wilson, S. Panda, A. C. Schmidt, and L. A. Sombers, Anal Chem, 90, 888 (2018)

114. N. Lavanya, S. Radhakrishnan, and C. Sekar, Biosensors \& bioelectronics, 36, 41 (2012)

115. J. Zhu, X. Gong, M. Zhang, C. Zheng, N. Chen, G. Sandford, Q. Wu, W. Huang, and D. Gao, Electroanalysis, 29, 696 (2017).

116. P. Karam and L. I. Halaoui, Anal Chem, 80, 5441 (2008)

117. J. L. Lyon and K. J. Stevenson, Anal Chem, 78, 8518 (2006)

118. V. Mirceski, S. Komorsky-Lovric, and M. Lovric, Square-Wave Voltammetry: Theory and Application, Springer Berlin Heidelberg (2007)

119. T. Wang, L. Wang, J. Tu, H. Xiong, and S. Wang, Bioelectrochemistry, 94, 94 (2013)

120. C. Batchelor-McAuley, E. Katelhon, E. O. Barnes, R. G. Compton, E. Laborda, and A. Molina, ChemistryOpen, 4, 224 (2015).

121. V. Mirčeski, L. Stojanov, and S. Skrzypek, Contributions, Section of Natural, Math ematical and Biotechnical Sciences, 39, 103 (2018).

122. M. Bozem, P. Knapp, V. Mirceski, E. J. Slowik, I. Bogeski, R. Kappl, C. Heinemann, and M. Hoth, Antioxidants \& redox signaling, 29, 501 (2018)

123. N. J. Ronkainen, H. B. Halsall, and W. R. Heineman, Chemical Society reviews, 39, 1747 (2010)

124. J. M. Goran, E. N. Phan, C. A. Favela, and K. J. Stevenson, Anal Chem, 87, 5989 (2015).

125. B. C. Liu, X. Y. Lu, X. Song, K. Y. Lei, A. A. Alli, H. F. Bao, D. C. Eaton, and H. P. Ma, Frontiers in physiology, 3, 483 (2012).

126. D. W. Kimmel, G. LeBlanc, M. E. Meschievitz, and D. E. Cliffel, Anal Chem, 84, $685(2012)$

127. G. Flatgen, S. Wasle, M. Lubke, C. Eickes, G. Radhakrishnan, K. Doblhofer, and G. Ertl, Electrochimica Acta, 44, 4499 (1999)

128. P. Gao and D. Liu, Sensors and Actuators B: Chemical, 208, 346 (2015).

129. K. Sugiyama and K. Aoki, Journal of Electroanalytical Chemistry, 261, 437 (1989).

130. L. Agui, P. Yanez-Sedeno, and J. M. Pingarron, Analytica chimica acta, 622, 11 (2008).

131. X. Zhang, H. Ju, and J. Wang, Electrochemical Sensors, Biosensors and their Biomedical Applications, Elsevier Science (2011).

132. Y. Mukouyama, S. Nakanishi, H. Konishi, K. Karasumi, and Y. Nakato, Physical Chemistry Chemical Physics, 3, $3284(2001)$. 
133. M. Shafei and K. C. Honeychurch, Analytical Methods, 5, 6631 (2013).

134. M. V. Vazquez, S. R. Desanchez, E. J. Calvo, and D. J. Schiffrin, Journal of Electroanalytical Chemistry, 374, 179 (1994).

135. R. C. Alkire, P. N. Bartlett, and J. Lipkowski, Electrochemistry of Carbon Electrodes, Wiley (2016).

136. C. Amatore, S. Arbault, C. Bouton, K. Coffi, J. C. Drapier, H. Ghandour, and Y. Tong, Chembiochem: a European journal of chemical biology, 7, 653 (2006).

137. C. B. Jacobs, M. J. Peairs, and B. J. Venton, Analytica chimica acta, 662, 105 (2010)

138. W. Chen, S. Cai, Q. Q. Ren, W. Wen, and Y. D. Zhao, The Analyst, 137, 49 (2012)

139. J. M. Pingarrón, P. Yáñez-Sedeño, and A. González-Cortés, Electrochimica Acta, 53, 5848 (2008)

140. Y. Zhou, G. Yu, F. Chang, B. Hu, and C. J. Zhong, Analytica chimica acta, 757, 56 (2012).

141. D. Hernandez-Santos, M. B. Gonzalez-Garcia, and A. C. Garcia, Electroanalysis, 14, 1225 (2002)

142. C. Wang and X. Hu, Talanta, 68, 1322 (2006).

143. A. Y. Khan and R. Bandyopadhyaya, Journal of Electroanalytical Chemistry, 727, 184 (2014).

144. F Gao, Z Li, and D Ruan, and G. Z., J Nanosci Nanotechnol., 14, 6599 (2014).

145. B. Habibi and M. Jahanbakhshi, Sensors and Actuators B: Chemical, 203, 919 (2014).

146. Y. Liu, G. Sun, C. Jiang, X. T. Zheng, L. Zheng, and C. M. Li, Microchimica Acta, 181, 63 (2014)

147. P. M. Nia, W. P. Meng, and Y. Alias, Appl Surf Sci, 357, 1565 (2015).

148. L.-C. Chang, H.-N. Wu, C.-Y. Lin, Y.-H. Lai, C.-W. Hu, and K.-C. Ho, Nanoscale Research Letters 2012, 7, 319 (2012).

149. M. Janyasupab, Y. Zhang, P.-Y. Lin, B. Bartling, J. Xu, and C.-C. Liu, Journal of Nanotechnology, 2011, 1 (2011).

150. P. Jakubec, V. Urbanová, Z. Marková, and R. Zbořil, Electrochimica Acta, 153, 62 (2015).

151. C. Chen, X. Hong, T. Xu, A. Chen, L. Lu, and Y. Gao, J. Electrochem. Soc., 162, H699 (2015).

152. M. R. Guascito, D. Chirizzi, C. Malitesta, E. Mazzotta, M. Siciliano, T. Siciliano, A. Tepore, and A. Turco, Biosensors \& bioelectronics, 26, 3562 (2011).

153. A. Uzunoglu, A. D. Scherbarth, and L. A. Stanciu, Sensors and Actuators B: Chem ical, 220, 968 (2015)

154. T. Marimuthu, M. R. Mahmoudian, S. Mohamad, and Y. Alias, Sensors and Actua tors B: Chemical, 202, 1037 (2014).

155. A. A. Abdelwahab and Y.-B. Shim, Sensors and Actuators B: Chemical, 201, 51 (2014).

156. T. Sirisaeng, P. Thavarungkul, P. Kanatharana, and W. Limbut, J. Electrochem. Soc., 165, B74 (2018)

157. J. Yang, H. Xiang, L. Shuai, and S. Gunasekaran, Analytica chimica acta, 708, 44 (2011).

158. M. Willander, K. Khun, and Z. H. Ibupoto, Sensors, 14, 8605 (2014)

159. D. Chirizzi, M. R. Guascito, E. Filippo, and A. Tepore, Talanta, 147, 124 (2016).

160. M. R. Guascito, D. Chirizzi, C. Malitesta, T. Siciliano, and A. Tepore, Talanta, 115, 863 (2013).

161. R. Gulaboski, M. Chirea, C. M. Pereira, M. N. D. S. Cordeiro, R. B. Costa, and A. F. Silva, J Phys Chem C, 112, 2428 (2008).

162. S. Chakraborty and C. R. Raj, Biosensors \& bioelectronics, 24, 3264 (2009)

163. X. Bo, J. Bai, J. Ju, and L. Guo, Analytica chimica acta, 675, 29 (2010).

164. R. Thangamuthu, Y. C. Pan, and S. M. Chen, Sensor Actuat B-Chem, 151, 377 (2011).

165. C. Zhu, G. Yang, H. Li, D. Du, and Y. Lin, Anal Chem, 87, 230 (2015)

166. M. Chirea, V. Garcia-Morales, J. A. Manzanares, C. Pereira, R. Gulaboski, and F. Silva, J Phys Chem B, 109, 21808 (2005).

167. W. Schuhmann, Journal of biotechnology, 82, 425 (2002).

168. A. L. Eckermann, D. J. Feld, J. A. Shaw, and T. J. Meade, Coordination chemistry reviews, 254, 1769 (2010).

169. M. L. Lian, X. Chen, Y. L. Lu, and W. S. Yang, ACS applied materials \& interfaces 8, 25036 (2016).

170. E. Canbay, B. Sahin, M. Kiran, and E. Akyilmaz, Bioelectrochemistry, 101, 126 (2015).

171. M. Y. Hua, H. C. Chen, R. Y. Tsai, Y. C. Lin, and L. Wang, Analytica chimica acta 693, 114 (2011).

172. A. Salimi, R. Hallaj, S. Soltanian, and H. Mamkhezri, Analytica chimica acta, 594, 24 (2007).

173. Y. H. Bai, H. Zhang, J. J. Xu, and H. Y. Chen, J Phys Chem C, 112, 18984 (2008).

174. S. Thangavel and R. Ramaraj, Journal of nanoscience and nanotechnology, 9, 2353 (2009).

175. L. R. Kong, X. F. Lu, X. J. Bian, W. J. Zhang, and C. Wang, Langmuir: the ACS journal of surfaces and colloids, 26, 5985 (2010).

176. Y. H. Wang, X. J. Yang, J. Bai, X. Jiang, and G. Y. Fan, Biosensors \& bioelectronics, 43, 180 (2013).

177. H. Razmi, M. Jabbari, and R. Mohammad-Rezaei, J Chin Chem Soc-Taip, 60, 1484 (2013).

178. T. Y. Wang, H. C. Zhu, J. Q. Zhuo, Z. W. Zhu, P. Papakonstantinou, G. Lubarsky, J. Lin, and M. X. Li, Analytical chemistry, 85, 10289 (2013).

179. Y. J. Li, K. Ye, K. Cheng, D. X. Cao, Y. Pan, S. Y. Kong, X. M. Zhang, and G. L. Wang, Journal of Electroanalytical Chemistry, 727, 154 (2014)

180. X. Qin, H. C. Wang, Z. Y. Miao, J. L. Li, and Q. Chen, Talanta, 139, 56 (2015).

181. L. Wang, Y. Zhang, C. Cheng, X. Liu, H. Jiang, and X. Wang, ACS applied materials \& interfaces, 7, $18441(2015)$
182. F. Xiao, L. Wang, and H. Duan, Biotechnology advances, 34, 234 (2016).

183. C. L. Zhao, H. F. Zhang, and J. B. Zheng, Journal of Electroanalytical Chemistry, 784, 55 (2017).

184. W. Putzbach and N. J. Ronkainen, Sensors, 13, 4811 (2013).

185. A. A. Ensafi, M. Jafari-Asl, and B. Rezaei, Talanta, 103, 322 (2013).

186. A. Hayat, G. Catanante, and J. L. Marty, Sensors, 14, 23439 (2014).

187. S. A. Bhakta, E. Evans, T. E. Benavidez, and C. D. Garcia, Analytica chimica acta, 872, 7 (2015)

188. L. Wang, S. Tricard, P. Yue, J. Zhao, J. Fang, and W. Shen, Biosensors \& bioelectronics, 77, 1112 (2016)

189. S. Yu, G. Zou, and Q. Wei, Talanta, 156-157, 11 (2016).

190. R. Li, X. Liu, W. Qiu, and M. Zhang, Anal Chem, 88, 7769 (2016)

191. W. Xu, J. Liu, M. Wang, L. Chen, X. Wang, and C. Hu, Analytica chimica acta, 913 , $128(2016)$

192. X. W. Du, Y. Chen, W. Dong, B. G. Han, M. Liu, Q. Chen, and J. Zhou, Oncotarget, 8, 13039 (2017).

193. F. Y. Kong, W. W. Li, J. Y. Wang, H. L. Fang, D. H. Fan, and W. Wang, Analytica chimica acta, 884, 37 (2015).

194. M. Baghayeri and H. Veisi, Biosensors \& bioelectronics, 74, 190 (2015)

195. X. Li, X. Liu, W. Wang, L. Li, and X. Lu, Biosensors \& bioelectronics, 59, 221 (2014)

196. X. Sun, S. Guo, Y. Liu, and S. Sun, Nano letters, 12, 4859 (2012).

197. T. C. Nagaiah, D. Schafer, W. Schuhmann, and N. Dimcheva, Anal Chem, 85, 7897 (2013).

198. B. J. Plowman, B. Sidhureddy, S. V. Sokolov, N. P. Young, A. Chen, and R. G. Compton, ChemElectroChem, 3, 1039 (2016).

199. Y. Sun, M. Luo, X. Meng, J. Xiang, L. Wang, Q. Ren, and S. Guo, Anal Chem, 89, 3761 (2017)

200. W. Wang, L. Kong, J. Zhu, and L. Tan, Journal of colloid and interface science, $\mathbf{4 9 8 ,}$ 1 (2017).

201. T. H. Tsai, S. Thiagarajan, and S. M. Chen, Journal of Applied Electrochemistry, 40, 2071 (2010).

202. X. Gao, S. He, C. Zhang, C. Du, X. Chen, W. Xing, S. Chen, A. Clayborne, and W. Chen, Advanced science, 3, 1600126 (2016).

203. Y. Wang, J.-M. Noel, J. Velmurugan, W. Nogala, M. Mirkin, C. Lu, M. Collignon, F. Lemaitre, and C. Amatore, PNAS, 109, 11534 (2012).

204. J. Wang, Z. Wang, D. Zhao, and C. Xu, Analytica chimica acta, 832, 34 (2014).

205. D. Cheng, X. Li, Y. Qiu, Q. Chen, J. Zhou, Y. Yang, Z. Xie, and A. W. C. A. C. Z. B. Peng Liu, Anal.Methods, 2017, 9,2082 (2017).

206. C. M. Silveira and M. G. Almeida, Analytical and bioanalytical chemistry, 405, 3619 (2013)

207. V. S. Tripathi, V. B. Kandimalla, and H. Ju, Biosensors \& bioelectronics, 21, 1529 (2006).

208. F. Ricci and G. Palleschi, Biosensors \& bioelectronics, 21, 389 (2005)

209. J. Clausmeyer, J. Henig, W. Schuhmann, and N. Plumere, Chemphyschem: a European journal of chemical physics and physical chemistry, 15, 151 (2014).

210. M. S. Lin and H. J. Len, Electroanalysis, 17, 2068 (2005).

211. Y. C. Wu, R. Thangamuthu, and S. M. Chen, Electroanalysis, 21, 210 (2009)

212. K. Barman and S. Jasimuddin, Rsc Adv, 6, 20800 (2016).

213. A. J. Bard and M. V. Mirkin, Scanning Electrochemical Microscopy, Second Edition, CRC Press (2012).

214. A. C. Testa and W. H. Reinmuth, Analytical chemistry, 33, 1320 (1961).

215. V. Mirceski and R. Gulaboski, J Solid State Electr, 7, 157 (2003).

216. R. Gulaboski and V. Mirceski, Electrochimica Acta, 167, 219 (2015).

217. U. Wollenberger, R. Spricigo, S. Leimkuhler, and K. Schroder, Advances in biochemical engineering/biotechnology, 109, 19 (2008).

218. S. A. Rothwell, S. J. Killoran, and R. D. O'Neill, Sensors, 10, 6439 (2010).

219. T. Noll and G. Noll, Chemical Society reviews, 40, 3564 (2011).

220. A. Sassolas, L. J. Blum, and B. D. Leca-Bouvier, Biotechnology advances, 30, 489 (2012)

221. A. J. S. Ahammad, Journal of Biosensors \& Bioelectronics, $\mathbf{s 9}$ (2012).

222. B. Cardenas-Benitez, I. Djordjevic, S. Hosseini, M. J. Madou, and S. O. Martinez-Chapa, J. Electrochem. Soc., 165(3), B103 (2018).

223. S. Q. Liu and H. X. Ju, Anal Biochem, 307, 110 (2002).

224. F. Gao, R. Yuan, Y. Chai, S. Chen, S. Cao, and M. Tang, Journal of biochemical and biophysical methods, 70, 407 (2007).

225. Z. Chen, S. Xie, L. Shen, Y. Du, S. He, Q. Li, Z. Liang, X. Meng, B. Li, X. Xu, H. Ma, Y. Huang, and Y. Shao, The Analyst, 133, 1221 (2008).

226. Y. Peng, D. L. Jiang, L. Su, L. Zhang, M. Yan, J. J. Du, Y. F. Lu, Y. N. Liu, and F. M. Zhou, Analytical chemistry, 81, 9985 (2009).

227. D. Y. Lu L, J Wang, Q Li, and X Wu, Anal.Methods, 7, 6686 (2015)

228. A. Prasad, H. Kikuchi, K. Y. Inoue, M. Suzuki, Y. Sugiura, T. Sugai, A. Tomonori, M. Tada, M. Kobayashi, T. Matsue, and S. Kasai, Frontiers in physiology, 7, 109 (2016)

229. H. Kikuchi, A. Prasad, R. Matsuoka, S. Aoyagi, T. Matsue, and S. Kasai, Frontiers in physiology, 7, 25 (2016).

230. K.-D. Seo, K.-P. Lee, A. I. Gopalan, S. J. Chung, Y. T. Lim, and S.-H. Choi, Sensors, 7, 719 (2007)

231. C. Ren, Y. Song, Z. Li, and G. Zhu, Analytical and bioanalytical chemistry, $\mathbf{3 8 1}$, 1179 (2005)

232. H. J. Kim, M. H. Piao, S. H. Choi, C. H. Shin, and Y. T. Lee, Sensors, 8, 4110 (2008).

233. P. Wu, Z. Cai, J. Chen, H. Zhang, and C. Cai, Biosensors \& bioelectronics, 26, 4012 (2011).

234. E. Suraniti, S. Ben-Amor, P. Landry, M. Rigoulet, E. Fontaine, S. Bottari, A. Devin, N. Sojic, N. Mano, and S. Arbault, Angew. Chem. Int. Ed., 53, 6655 (2014). 
235. K. B. O’Brien, S. J. Killoran, R. D. O'Neill, and J. P. Lowry, Biosensors \& bioelectronics, 22, 2994 (2007).

236. P. A. Prakash, U. Yogeswaran, and S. M. Chen, Sensors, 9, 1821 (2009).

237. E. Akyilmaz, G. Oyman, E. Cinar, and G. Odabas, Preparative biochemistry \& biotechnology, 47, 86 (2017).

238. A. T. E. Vilian, S.-M. Chen, and B. S. Lou, Biosensors \& bioelectronics, 61, 639 (2014).

239. W. Dong, K. Wang, Y. Chen, W. Li, Y. Ye, and S. Jin, Materials, 10 (2017)

240. S. George and H. K. Lee, Journal of Physical Chemistry B, 113, 15445 (2009).

241. X. Xu, L. Song, Q. Zheng, X. Cao, and C. Yao, Electroanalysis, 29, 765 (2017)

242. N. Akhtar, S. El-Safty, and M. Khairy, Chemosensors, 2, 235 (2014).

243. L. Peng, A. Yarman, K. J. Jetzschmann, J. H. Jeoung, D. Schad, H. Dobbek, U. Wollenberger, and F. W. Scheller, Sensors, 16, 272 (2016).

244. A. T. E. Vilian, S.-M. Chen, C. H. Kwak, S.-K. Hwang, Y. S. Huh, and Y.-K. Han, Sensors and Actuators B: Chemical, 224, 607 (2016).

245. J. D. Qiu, H. P. Peng, R. P. Liang, and X. H. Xia, Biosensors \& bioelectronics, 25, 1447 (2010).

246. Y. Li, Y. Li, and Y. Yang, Bioelectrochemistry, 82, 112 (2011)

247. A. K. Yagati, T. Lee, J. Min, and J. W. Choi, Biosensors \& bioelectronics, 47, 385 (2013).

248. K. Zhan, H. Liu, H. Zhang, Y. Chen, H. Ni, M. Wu, D. Sun, and Y. Chen, Journal of Electroanalytical Chemistry, 724, 80 (2014).

249. A. Chaubey and B. D. Malhotra, Biosensors \& bioelectronics, 17, 441 (2002).

250. H. X. Ju, S. Q. Liu, B. X. Ge, F. Lisdat, and F. W. Scheller, Electroanalysis, 14, 141 (2002).

251. A. K. Yagati, T. Lee, J. Min, and J. W. Choi, Colloid Surface B, 92, 161 (2012).

252. S. E. Salamifar, S. Lee, and R. Y. Lai, Colloids Surf B Biointerfaces, 123, 866 (2014).

253. K. Takeda, T. Uchihashi, H. Watanabe, T. Ishida, K. Igarashi, N. Nakamura, and H. Ohno, PloS one, 10, e0116685 (2015).

254. F. A. Armstrong, Current opinion in chemical biology, 9, 110 (2005)

255. A. K. Yagati, T. Lee, J. Min, and J. W. Choi, Bioelectrochemistry, 80, 169 (2011).

256. N. Akhtar, S. A. El-Safty, M. Khairy, and W. A. El-Said, Sensors and Actuators B Chemical, 207, 158 (2015).

257. M. A. Komkova, A. Holzinger, A. Hartmann, A. R. Khokhlov, C. Kranz, A. A. Karyakin, and O. G. Voronin, Beilstein journal of nanotechnology, 4, 649 (2013).

258. A. K. M. Kafi, G. Wu, and A. Chen, Biosensors \& bioelectronics, 24, 566 (2008).

259. Z. J. Cao, X. Q. Jiang, Q. J. Xie, and S. Z. Yao, Biosensors \& bioelectronics, 24, $222(2008)$.

260. C. X. Guo, F. P. Hu, C. M. Li, and P. K. Shen, Biosensors \& bioelectronics, 24, 819 (2008).

261. X. C. Tan, J. L. Zhang, S. W. Tan, D. D. Zhao, Z. W. Huang, Y. Mi, and Z. Y. Huang, Sensors, 9, 6185 (2009).

262. J. L. Huang and Y. C. Tsai, Sensor Actuat B-Chem, 140, 267 (2009).

263. Y. Ding, W. Z. Jia, H. Zhang, B. K. Li, Z. Y. Gu, and Y. Lei, Electroanalysis, 22, 1911 (2010).

264. M. Senel, E. Cevik, and M. F. Abasiyanik, Sensor Actuat B-Chem, 145, 444 (2010).

265. M. Jamal, J. Xu, and K. M. Razeeb, Biosensors \& bioelectronics, 26, 1420 (2010).

266. Y. Song and G. R. Buettner, Free radical biology \& medicine, 49, 919 (2010).

267. J. Xu, C. H. Liu, and Y. L. Teng, Microchimica Acta, 169, 181 (2010).

268. F. Guo, X. X. Xu, Z. Z. Sun, J. X. Zhang, Z. X. Meng, W. Zheng, H. M. Zhou, B. L. Wang, and Y. F. Zheng, Colloid Surface B, 86, 140 (2011).

269. D. G. McMillan, S. J. Marritt, G. L. Kemp, P. Gordon-Brown, J. N. Butt, and L. J. Jeuken, Electrochimica acta, 110, 79 (2013)

270. P. Yáñez-Sedeño, J. M. Pingarrón, J. Riu, and F. X. Rius, TrAC Trends in Analytical Chemistry, 29, 939 (2010).

271. C. Carucci, A. Salis, and E. Magner, Current Opinion in Electrochemistry, 5, 158 (2017).

272. P. Li, Y. Ding, Z. Lu, Y. Chen, Y. Zhou, Y. Tang, C. Cai, and T. Lu, Analytica chimica acta, 786, 34 (2013).

273. S. Cinti, F. Arduini, D. Moscone, G. Palleschi, and A. J. Killard, Sensors, 14, 14222 (2014).

274. J. Zheng, J. Diao, Y. Jin, A. Ding, B. Wang, L. Wu, B. Weng, and J. Chen, Journal of the Electrochemical Society, 165, B227 (2018).

275. Z. H. Li, H. Guedri, B. Viguier, S. G. Sun, and J. L. Marty, Sensors, 13, 5028 (2013).

276. X. Xu, S. Liu, and H. Ju, Sensors, 3, 350 (2003).

277. K. Novoselov and AK Geim, Science, 306, 666 (2004).

278. O. C. Compton and S. T. Nguyen, Small, 6, 711 (2010).

279. J. L. Hammond, N. Formisano, P. Estrela, S. Carrara, and J. Tkac, Essays in biochemistry, 60, 69 (2016).

280. H. Gao and H. Duan, Biosensors \& bioelectronics, 65, 404 (2015).

281. D. Chen, L. Tang, and J. Li, Chemical Society reviews, 39, 3157 (2010).

282. J. Filip, P. Kasak, and J. Tkac, Chem Zvesti, 69, 112 (2015).

283. R. Zhang and W. Chen, Biosensors \& bioelectronics, 89, 249 (2017).

284. X. Bo, M. Zhou, and L. Guo, Biosensors \& bioelectronics, 89, 167 (2017).

285. S. K. Vashist, D. Zheng, K. Al-Rubeaan, J. H. Luong, and F. S. Sheu, Biotechnology advances, 29, 169 (2011)

286. X. Yu, W. Zhang, P. Zhang, and Z. Su, Biosensors \& bioelectronics, 89, 72 (2017).

287. Y. Sun, K. He, Z. Zhang, A. Zhou, and H. Duan, Biosensors \& bioelectronics, 68 358 (2015).

288. A. T. Lawal, Talanta, 131, 424 (2015).

289. S. Mutyala and J. Mathiyarasu, Materials science \& engineering. C, Materials for biological applications, 69, 398 (2016).
290. V. Velusamy, S. Palanisamy, S.-M. Chen, T.-W. Chen, S. Selvam, S. K. Ramaraj, and B.-S. Lou, Sensors and Actuators B: Chemical, 252, 175 (2017).

291. G. Chen, H. Sun, and S. Hou, Anal Biochem, 502, 43 (2016).

292. Z. Gu, S. Yang, Z. Li, X. Sun, G. Wang, Y. Fang, and J. Liu, Analytica chimica acta, 701, 75 (2011).

293. L. Zheng, D. Ye, L. Xiong, J. Xu, K. Tao, Z. Zou, D. Huang, X. Kang, S. Yang, and J. Xia, Analytica chimica acta, 768, 69 (2013).

294. M. Liu, R. Liu, and W. Chen, Biosensors \& bioelectronics, 45, 206 (2013).

295. S. Dong, J. Xi, Y. Wu, H. Liu, C. Fu, H. Liu, and F. Xiao, Analytica chimica acta, 853, 200 (2015)

296. H. Liu, K. Guo, C. Duan, X. Dong, and J. Gao, Biosensors \& bioelectronics, 87, 473 (2017).

297. B. Habibi, F. Azhar, J. Fakkar, and Z. Rezvani, Anal. Methods, 9, 1956 (2017).

298. H. Chang, X. Wang, K. K. Shiu, Y. Zhu, J. Wang, Q. Li, B. Chen, and H. Jiang, Biosensors \& bioelectronics, 41, 789 (2013).

299. F. Xu, M. Deng, G. Li, S. Chen, and L. Wang, Electrochimica Acta, 88, 59 (2013).

300. W. Liu, H. Zhang, B. Yang, Z. Li, L. Lei, and X. Zhang, Journal of Electroanalytical Chemistry, 749, 62 (2015)

301. P. Moozarm Nia, F. Lorestani, W. P. Meng, and Y. Alias, Appl Surf Sci, 332, 648 (2015)

302. A. Uzunoglu, S. Song, and L. A. Stanciu, J. Electrochem. Soc., 163, B379 (2016).

303. Z. Yang, X. Zheng, and J. Zheng, J. Electrochem. Soc., 163, B466 (2016).

304. C. Revathi, K. Rajavel, M. Saranya, and R. T. R. Kumar, J. Electrochem. Soc., 163, B627 (2016).

305. A. K. Nair, K. M. Sukumaran Nair, S. Thomas, D. Rouxel, S. Alwarappan, and N. Kalarikkal, Langmuir: the ACS journal of surfaces and colloids, 34, 13603 (2018).

306. L. Cao, Y. Liu, B. Zhang, and L. Lu, ACS applied materials \& interfaces, 2, 2339 (2010).

307. F. Li, M. Xue, X. Ma, M. Zhang, and T. Cao, Anal Chem, 83, 6426 (2011)

308. H. Song, Y. Ni, and S. Kokot, Analytica chimica acta, 788, 24 (2013).

309. Z. Yu, L. Zou, Y. Chen, and J. Jiang, ACS applied materials \& interfaces, 8, 30398 (2016)

310. H. Min, W. Wu, H. Wu, S. Wang, C. Feng, and Y. Ding, Electroanalysis, 29, 730 (2017).

311. H. C. Chen, Y. M. Tu, C. C. Hou, Y. C. Lin, C. H. Chen, and K. H. Yang, Analytica chimica acta, 867, 83 (2015).

312. H. Yang, Z. Wang, C. Li, and C. Xu, Journal of colloid and interface science, 491, 321 (2017)

313. Z. Zhang, S. Gu, Y. Ding, and J. Jin, Analytica chimica acta, 745, 112 (2012).

314. V. C. Soorya and S. Berchmans, J. Electrochem. Soc., 164, B435 (2017).

315. J. Tashkhourian, M. R. Hormozi-Nezhad, J. Khodaveisi, and R. Dashti, Analytica chimica acta, 762, 87 (2013).

316. C. Xu, J. Wang, and J. Zhou, Sensors and Actuators B: Chemical, 182, 408 (2013).

317. N. S. Sangeetha and S. S. Narayanan, Analytica chimica acta, 828, 34 (2014).

318. C. Xu, F. Sun, H. Gao, and J. Wang, Analytica chimica acta, 780, 20 (2013).

319. L. Zhang, F. Yuan, X. Zhang, and L. Yang, Chemistry Central journal, 5, 75 (2011).

320. S. Li, J. Qu, Y. Wang, J. Qu, and H. Wang, Anal.Methods, 8, 4204 (2016).

321. M. Zhou, Y. Yu, K. Hu, and M. V. Mirkin, Journal of the American Chemical Society, 137, 6517 (2015)

322. S. Mesaros, Z. Vankova, S. Grunfeld, A. Mesarosova, and T. Malinski, Analytica chimica acta, 358, 27 (1998).

323. X. Zhu, X. Niu, H. Zhao, J. Tang, and M. Lan, Biosensors \& bioelectronics, 67, 79 (2015).

324. C. J. McNeil, K. R. Greenough, P. A. Weeks, C. H. Self, and J. M. Cooper, Free Radical Res Com, 17, 399 (1992).

325. P. Manning, C. J. McNeil, J. M. Cooper, and E. W. Hillhouse, Free Radical Bio Med, 24, 1304 (1998).

326. K. Tammeveski, T. T. Tenno, A. A. Mashirin, E. W. Hillhouse, P. Manning, and C. J. McNeil, Free Radical Bio Med, 25, 973 (1998).

327. X. J. J. Chen, A. C. West, D. M. Cropek, and S. Banta, Analytical chemistry, 80, 9622 (2008).

328. K. Tanaka, T. Tsuyama, Y. Karatsu, and T. Iizuka, Bioelectroch Bioener, 41, 201 (1996)

329. H. J. Forman and M. Torres, American journal of respiratory and critical care medicine, 166, S4 (2002)

330. S. O'Riordan, K. Mc Laughlin, and J. Lowry, Analytical Methods, 8, 7614 (2016).

331. C. H. Reid and N. J. Finnerty, Sensors, 17 (2017).

332. C. Amatore, S. Arbault, M. Guille, and F. Lemaitre, Chemical reviews, 108, 2585 (2008).

333. S. Li, A. J. Case, R. F. Yang, H. D. Schultz, and M. C. Zimmerman, Redox biology, 2, 8 (2013)

334. C. Amatore, S. Arbault, Y. Chen, C. Crozatier, and I. Tapsoba, Lab on a chip, 7, 233 (2007)

335. Y. Zhang, X. Bai, X. Wang, K. K. Shiu, Y. Zhu, and H. Jiang, Anal Chem, 86, 9459 (2014).

336. J. Xi, Y. Zhang, N. Wang, L. Wang, Z. Zhang, F. Xiao, and S. Wang, ACS applied materials \& interfaces, 7, 5583 (2015).

337. J. Liu, X. Bo, Z. Zhao, and L. Guo, Biosensors \& bioelectronics, 74, 71 (2015).

338. M. Asif, A. Aziz, A. Q. Dao, A. Hakeem, H. Wang, S. Dong, G. Zhang, F. Xiao, and H. Liu, Analytica chimica acta, 898, 34 (2015).

339. C. Li, X. Liu, Y. Zhang, Y. Chen, T. Du, H. Jiang, and X. Wang, Analytica chimica acta, 933, 66 (2016).

340. L. Yao, Y. Yan, and J.-M. Lee, ACS Sustainable Chemistry \& Engineering, 5, 1248 (2017).

341. J. Yan, V. A. Pedrosa, J. Enomoto, A. L. Simonian, and A. Revzin, Biomicrofluidics, 5, 32008 (2011) 
342. K. Y. Inoue, K. Ino, H. Shiku, S. Kasai, T. Yasukawa, F. Mizutani, and T. Matsue, Biosensors \& bioelectronics, 25, 1723 (2010).

343. P. Wu, Z. Cai, Y. Gao, H. Zhang, and C. Cai, Chem. Commun., 47 (2011).

344. T. Finkel, S. Menazza, K. M. Holmstrom, R. J. Parks, J. Liu, J. Sun, J. Liu, X. Pan, and E. Murphy, Circulation research, 116, 1810 (2015).

345. F. Xiao, J. Song, H. Gao, X. Zan, R. Xu, and H. Duan, ACS nano, 6, 100 (2012).

346. H. J. Qiu, Y. Guan, P. Luo, and Y. Wang, Biosensors \& bioelectronics, 89, 85 (2017)

347. L. Zhu, Y. Zhang, P. Xu, W. Wen, X. Li, and J. Xu, Biosensors \& bioelectronics, 80, 601 (2016).

348. A. J. Bard, Anal. Chem., 61, 132 (1989).

349. S. Amemiya, A. J. Bard, F. R. Fan, M. V. Mirkin, and P. R. Unwin, Annual review of analytical chemistry, 1, 95 (2008).

350. C. G. Zoski, C. R. Luman, J. L. Fernandez, and A. J. Bard, Analytical chemistry, 79, 4957 (2007)

351. J. Mauzeroll and A. J. Bard, Proceedings of the National Academy of Sciences of the United States of America, 101, 7862 (2004).

352. S. Kuss, C. Kuss, D. Trinh, S. B. Schougaard, and J. Mauzeroll, Electrochimica Acta, 110, 42 (2013).

353. D. Polcari, P. Dauphin-Ducharme, and J. Mauzeroll, Chemical reviews, 116, 13234 (2016).

354. S. Bergner, P. Vatsyayan, and F. M. Matysik, Analytica chimica acta, 775, 1 (2013).

355. X. Zhao, P. Diakowski, and Z. Ding, Anal. Chem., 82, 8371 (2010).

356. A. L. Whitworth, D. Mandler, and P. R. Unwin, Phys. Chem. Chem. Phys., 7, 356 (2005).

357. M. A. Edwards, S. Martin, A. L. Whitworth, J. V. Macpherson, and P. R. Unwin, Physiological measurement, 27, R63 (2006).

358. W. S. Roberts, D. J. Lonsdale, J. Griffiths, and S. P. Higson, Biosensors \& bioelectronics, 23, 301 (2007).

359. P. Sun, F. O. Laforge, and M. V. Mirkin, Physical chemistry chemical physics: PCCP, 9, 802 (2007).

360. A. J. Bard, X. Li, and W. Zhan, Biosensors \& bioelectronics, 22, 461 (2006).

361. N. Ebejer, A. G. Guell, S. C. Lai, K. McKelvey, M. E. Snowden, and P. R. Unwin, Annual review of analytical chemistry, 6, 329 (2013).

362. P. M. Diakowski and Z. Ding, Physical chemistry chemical physics: PCCP, 9, 5966 (2007).

363. K. Eckhard and W. Schuhmann, The Analyst, 133, 1486 (2008).

364. J. Ufheil, C. Hess, K. Borgwarth, and J. Heinze, Physical chemistry chemical physics: PCCP, 7, 3185 (2005).

365. C. G. Zoski, B. Liu, and A. J. Bard, Analytical chemistry, 76, 3646 (2004).

366. R. Engstrom, M. Weber, D. Wunder, R. Burgess, and S. Winquist, Anal Chem, 58, 844 (1986).

367. C. Kranz, The Analyst, 139, 336 (2014).

368. C. Amatore, C. Pebay, L. Thouin, A. Wang, and J.-S. Warkocz, Anal. Chem., 82 , 2585 (2010)

369. J. Heinze, Angew Chem Int Edit, 32, 1268 (1993).

370. K. Aoki, Electroanalysis, 5, 627 (1993).

371. D. A. Walsh, K. R. Lovelock, and P. Licence, Chemical Society reviews, 39, 4185 (2010).

372. J. K. Novev and R. G. Compton, Phys.Chem.Chem.Phys., 18, 29836 (2016).

373. J. K. Novev and R. G. Compton, Phys.Chem.Chem.Phys., 2017, 19, 12759 (2017)

374. J. K. Novev and R. G. Compton, Current Opinion in Electrochemistry, 7, 118 (2018)

375. M. C. Ribeiro, L. G. C. Rego, and P. C. T. D'Ajello, Journal of Electroanalytical Chemistry, 628, 21 (2009).

376. C. Sanchez-Sanchez and A. Bard, Anal. Chem., 81, 8094 (2009).

377. S. M. Oja and B. Zhang, Anal Chem, 86, 12299 (2014).

378. T. Matsue, Anal Sci, 29, 171 (2013).

379. L. Danis, M. E. Snowden, U. M. Tefashe, C. N. Heinemann, and J. Mauzeroll, Electrochimica Acta, 136, 121 (2014).

380. J. Gorelik, Y. Zhang, A. I. Shevchuk, G. I. Frolenkov, D. Sanchez, M. J. Lab, I. Vodyanoy, C. R. Edwards, D. Klenerman, and Y. E. Korchev, Molecular and cellular endocrinology, 217, 101 (2004).

381. Y. Takahashi, Y. Murakami, K. Nagamine, H. Shiku, S. Aoyagi, T. Yasukawa, M. Kanzaki, and T. Matsue, Physical chemistry chemical physics: PCCP, 12, 10012 (2010).

382. Y. E. Korchev, M. Milovanovic, C. L. Bashford, D. C. Bennett, E. V. Sviderskaya, I. Vodyanoy, and M. J. Lab, Journal of microscopy, 188, 17 (1997).

383. C. J. Meunier, E. C. Mitchell, J. G. Roberts, J. V. Toups, G. S. McCarty, and L. A. Sombers, Anal Chem, 90, 1767 (2018).

384. C. Zoski, Electroanalysis, 14 (2002).

385. S. Arbault, P. Pantano, J. A. Jankowski, M. Vuillaume, and C. Amatore, Anal Chem, 67, 3382 (1995).

386. Y. Chen, Q. Li, H. Jiang, and X. Wang, Journal of Electroanalytical Chemistry, $\mathbf{7 8 1}$ 233 (2016).

387. S. Ben-Amor, E. Vanhove, F. Sékli Belaïdi, S. Charlot, D. Colin, M. Rigoulet, A. Devin, N. Sojic, J. Launay, P. Temple-Boyer, and S. Arbault, Electrochimica Acta, 126, 171 (2014).

388. S. Kuss, R. Cornut, I. Beaulieu, M. A. Mezour, B. Annabi, and J. Mauzeroll, Bioelectrochemistry, 82, 29 (2011).

389. S. A. Rotenberg and M. V. Mirkin, J Mammary Gland Biol Neoplasia, 9, 375 (2004)

390. S. E. Salamifar and R. Y. Lai, Anal Chem, 85, 9417 (2013).

391. F. Antunes and E. Cadenas, FEBS letters, 475, 121 (2000).

392. R. D. M. Travasso, F. Sampaio Dos Aidos, A. Bayani, P. Abranches, and A. Salvador, Redox biology, 12, 233 (2017).

393. L. E. Tomalin, A. M. Day, Z. E. Underwood, G. R. Smith, P. Dalle Pezze, C. Rallis, W. Patel, B. C. Dickinson, J. Bahler, T. F. Brewer, C. J. Chang, D. P. Shanley, and E. A. Veal, Free radical biology \& medicine, 95, 333 (2016).
394. Y. Ni, H. Liu, D. Dai, X. Mu, J. Xu, and S. Shao, Anal Chem, 90, 10152 (2018).

395. R. G. Abisado, S. Benomar, J. R. Klaus, A. A. Dandekar, and J. R. Chandler, mBio, 9 (2018).

396. M. Jamal, U. Tasneem, T. Hussain, and S. Andlee, RRJMB, 4 (2015).

397. X. Liu, M. M. Ramsey, X. Chen, D. Koley, M. Whitley, and A. J. Bard, PNAS, vol. 108 (2011).

398. E. Abucayon, N. Ke, R. Cornut, A. Patelunas, D. Miller, M. K. Nishiguchi, and C. G. Zoski, Anal Chem, 86, 498 (2014).

399. S. Pinck, M. Etienne, M. Dossot, and F. P. A. Jorand, Bioelectrochemistry, 118, 131 (2017).

400. Y. Y. Yu, D. D. Zhai, R. W. Si, J. Z. Sun, X. Liu, and Y. C. Yong, International journal of molecular sciences, $\mathbf{1 8}$ (2017).

401. Y.-L. Ying, Z. Ding, D. Zhanc, and Y.-T. Long, Chem. Sci., 8, 3338 (2017).

402. P. Actis, S. Tokar, J. Clausmeyer, B. Babakinejad, S. Mikhaleva, R. Cornut, Y. Takahashi, A. L. Cordoba, P. Novak, A. I. Shevchuck, J. A. Dougan, S. G. Kazarian, P. V. Gorelkin, A. S. Erofeev, I. V. Yaminsky, P. R. Unwin, W. Schuhmann, D. Klenerman, D. A. Rusakov, E. V. Sviderskaya, and Y. E. Korchev, ACS nano, 8, 875 (2014).

403. M. Marquitan, J. Clausmeyer, P. Actis, A. L. Córdoba, Y. Korchev, M. D. Mark, S. Herlitze, and W. Schuhmann, ChemElectroChem, 3, 2125 (2016).

404. B. A. Wagner, J. R. Witmer, T. J. van 't Erve, and G. R. Buettner, Redox biology, 1, 210 (2013).

405. X. P. Liu and J. L. Zweier, Free Radical Bio Med, 31, 894 (2001).

406. M. A. Aon, S. Cortassa, and B. O'Rourke, Biochimica et biophysica acta, 1797, 865 (2010).

407. F. J. Rawson, J. Hicks, N. Dodd, W. Abate, D. J. Garrett, N. Yip, G. Fejer, A. J. Downard, K. H. Baronian, S. K. Jackson, and P. M. Mendes, ACS applied materials \& interfaces, 7, 23527 (2015).

408. R. Marcu, S. Rapino, M. Trinei, G. Valenti, M. Marcaccio, P. G. Pelicci, F. Paolucci, and M. Giorgio, Bioelectrochemistry, 85, 21 (2012).

409. I. Bogeski, R. Gulaboski, R. Kappl, V. Mirceski, M. Stefova, J. Petreska, and M. Hoth, Journal of the American Chemical Society, 133, 9293 (2011).

410. O. Ouari, M. Hardy, H. Karoui, and P. Tordo, Electron Paramagnetic Resonance, Specialist periodic Reports, 22, 1 (2011).

411. F. A. Villamena and J. L. Zweier, Antioxidants \& redox signaling, 6, 619 (2004).

412. G. Bartosz, Clinica chimica acta; international journal of clinical chemistry, $\mathbf{3 6 8}$, 53 (2006).

413. F. A. Villamena, Y. Liu, and J. L. Zweier, J. Phys. Chem. A, 112, 12607 (2008).

414. F. A. Villamena, S. Xia, J. K. Merle, R. Lauricella, B. Tuccio, C. M. Hadad, and J. L. Zweier, J. AM. CHEM. SOC., 129, 8177 (2007).

415. E. J. Locigno, J. L. Zweier, and F. A. Villamena, Organic \& biomolecular chemistry, 3, 3220 (2005)

416. N. Beziere, M. Hardy, F. Poulhes, H. Karoui, P. Tordo, O. Ouari, Y. M. Frapart, A. Rockenbauer, J. L. Boucher, D. Mansuy, and F. Peyrot, Free radical biology \& medicine, 67, 150 (2014).

417. C. Vergely, V. Maupoil, G. Clermont, A. Bril, and L. Rochette, Archives of biochemistry and biophysics, 420, 209 (2003).

418. E. A. Abdel-Rahman, A. M. Mahmoud, A. M. Khalifa, and S. S. Ali, The Journal of physiology, 594, 4591 (2016).

419. M. Elas, K. Ichikawa, and H. J. Halpern, Radiat Research, 177, 514 (2012).

420. J. G. Mohanty, J. S. Jaffe, E. S. Schulman, and D. G. Raible, Journal of immunological methods, 202, 133 (1997).

421. H. H. Gorris and D. R. Walt, J Am Chem Soc, 131, 6277 (2009).

422. M. Aoyama, M. Shiga, H. Ohya, and H. Kamada, Anal Sci, 14, 1107 (1998).

423. T. Matsuo, H. Shinzawa, H. Togashi, M. Aoki, K. Sugahara, K. Saito, T. Saito, T. Takahashi, I. Yamaguchi, M. Aoyama, and H. Kamada, Free radical biology \& medicine, 25, 929 (1998).

424. S. I. Dikalov, A. E. Dikalova, A. T. Bikineyeva, H. H. Schmidt, D. G. Harrison, and K. K. Griendling, Free radical biology \& medicine, 45, 1340 (2008).

425. S. Thierbach, N. Bui, J. Zapp, S. R. Chhabra, R. Kappl, and S. Fetzner, Chemistry \& biology, 21, 217 (2014).

426. S. Dikalov, K. K. Griendling, and D. G. Harrison, Hypertension, 49, 717 (2007).

427. S. I. Dikalov, I. A. Kirilyuk, M. Voinov, and I. A. Grigor'ev, Free radical research, 45, 417 (2011).

428. M. Kohno, Journal of Clinical Biochemistry and Nutrition, 47, 1 (2010).

429. S. I. Dikalov, Y. F. Polienko, and I. Kirilyuk, Antioxidants \& redox signaling, (2017).

430. G. Barriga-González, C. Olea-Azar, M. C. Zuñiga-López, C. Folch-Cano, B. Aguilera-Venegas, W. Porcal, M. González, and H. Cerecetto, Current Topics in Medicinal Chemistry, 15, 484 (2015).

431. K. Abbas, M. Hardy, F. Poulhès, H. Karoui, P. Tordo, O. Ouari, and F. Peyrot, Free radical research, $\mathbf{4 9}, 1122(2015)$.

432. M. J. Davies, Methods, 109, 21 (2016).

433. C. L. Hawkins and M. J. Davies, Biochimica et biophysica acta, 1840, 708 (2014).

434. K. Abbas, N. Babic, and F. Peyrot, Methods, 109, 31 (2016).

435. B. Gopalakrishnan, K. M. Nash, M. Velayutham, and F. A. Villamena, Journal of visualized experiments: JoVE, e2810 (2012).

436. K. Abbas, M. Hardy, F. Poulhès, H. Karoui, P. Tordo, O. Ouari, and F. Peyrot, Free Radical Bio Med, 71, 281 (2014).

437. S. I. Dikalov, W. Li, P. Mehranpour, S. S. Wang, and A. M. Zafari, Biochemical pharmacology, 73, 972 (2007)

438. B. Fink and S. Dikalov, Free Radical Bio Med, 33, S366 (2002)

439. V. V. Khramtsov, Antioxidants \& redox signaling, 28, 1365 (2018).

440. B. Gallez and H. M. Swartz, NMR in biomedicine, 17, 223 (2004). 
441. G. R. Eaton and S. S. Eaton, and K. O. (eds), CRC Press (2018).

442. G. S. Timmins, K. J. Liu, E. J. H. Bechara, Y. Kotake, and H. M. Swartz, Free radical biology \& medicine, 27, 329 (1999).

443. L. J. Berliner, Springer Science \& Business Media, 18, 656 (2012).

444. K. Sato, J. Corbett, R. P. Mason, and M. B. Kadiiska, Free radical research, 46, 645 (2012).

445. A. A. Bobko, T. D. Eubank, J. L. Voorhees, O. V. Efimova, I. A. Kirilyuk, S. Petryakov, D. G. Trofimiov, C. B. Marsh, J. L. Zweier, I. A. Grigor'ev, A. Samouilov, and V. V. Khramtsov, Magnetic resonance in medicine, 67, 1827 (2012).

446. A. A. Bobko, T. D. Eubank, B. Driesschaert, and V. V. Khramtsov, J. Vis. Exp., 133, e56624 (2018).

447. K. Takeshita and T. Ozawa, Journal of radiation research, 45, 373 (2004).

448. G. Maulucci, G. Bacic, L. Bridal, H. H. Schmidt, B. Tavitian, T. Viel, H. Utsumi, A. S. Yalcin, and M. De Spirito, Antioxidants \& redox signaling, 24, 939 (2016).

449. S. Kishimoto, M. C. Krishna, V. V. Khramtsov, H. Utsumi, and D. J. Lurie, Antioxidants \& redox signaling, 28, 1345 (2018).

450. H. Kubota, D. A. Komarov, H. Yasui, S. Matsumoto, O. Inanami, I. A. Kirilyuk, V. V. Khramtsov, and H. Hirata, Magma, 30, 291 (2017)

451. R. A. Towner and N. Smith, Antioxidants \& redox signaling, 28, 1404 (2018).

452. E. Vanea, N. Charlier, J. Dewever, M. Dinguizli, O. Feron, J. F. Baurain, and B. Gallez, NMR in biomedicine, 21, 296 (2008).

453. S. Liu, G. S. Timmins, H. Shi, C. M. Gasparovic, and K. J. Liu, NMR in biomedicine, 17, 327 (2004).

454. P. Kuppusamy and J. L. Zweier, NMR in biomedicine, 17, 226 (2004).

455. V. V. Khramtsov, Antioxidants \& redox signaling, 28, 1341 (2018).

456. G. Redler, E. D. Barth, K. S. Bauer Jr., J. P. Kao, G. M. Rosen, and H. J. Halpern, Magnetic resonance in medicine, 71, 1650 (2014).

457. S. Subramanian and M. C. Krishna, Magnetic Resonance Insights, 2, 43 (2008).

458. S. Stamenkovic, A. Pavicevic, M. Mojovic, A. Popovic-Bijelic, V. Selakovic, P. Andjus, and G. Bacic, Free radical biology \& medicine, 108, 258 (2017).

459. J. Koscielniak, N. Devasahayam, M. S. Moni, P. Kuppusamy, K. Yamada,
J. B. Mitchell, M. C. Krishna, and S. Subramanian, Review of Scientific Instruments, 71, 4273 (2000).

460. K. Mäder, B. Gallez, and H. M. Swartz, Appl. Radiat. Isot., 47, 1663 (1996).

461. H. M. Swartz, N. Khan, J. Buckey, R. Comi, L. Gould, O. Grinberg, A. Hartford, H. Hopf, H. Hou, E. Hug, A. Iwasaki, P. Lesniewski, I. Salikhov, and T. Walczak, NMR in biomedicine, 17, 335 (2004).

462. R. P. Mason, Redox biology, 8, 422 (2016).

463. R. P. Mason, Free radical biology \& medicine, 36, 1214 (2004).

464. R. A. Towner, P. Garteiser, F. Bozza, N. Smith, D. Saunders, J. C. d' Avila, F. Magno, M. F. Oliveira, M. Ehrenshaft, F. Lupu, R. Silasi-Mansat, D. C. Ramirez, S. E. Gomez-Mejiba, R. P. Mason, and H. C. Castro Faria-Neto, Free radical biology \& medicine, 65, 828 (2013).

465. S. E. Gomez-Mejiba, Z. Zhai, M. C. Della-Vedova, M. D. Munoz, S. Chatterjee, R. A. Towner, K. Hensley, R. A. Floyd, R. P. Mason, and D. C. Ramirez, Biochimica et biophysica acta, 1840, 722 (2014).

466. D. C. Ramirez and R. P. Mason, Current Protocols in Toxicology, 17.7.1 (2005).

467. D. C. Ramirez, S. E. Gomez-Mejiba, and R. P. Mason, Nature protocols, 2, 512 (2007).

468. M. F. Davis, L. Zhou, M. Ehrenshaft, K. Ranguelova, H. P. Gunawardena, X. Chen, M. G. Bonini, R. P. Mason, and S. L. Campbell, Free radical biology \& medicine, 53, 1339 (2012).

469. V. Deletioglu, E. Tuncay, A. Toy, M. Atalay, and B. Turan, Molecular and cellular biochemistry, 409, 23 (2015).

470. R. A. Towner, D. Saunders, N. Smith, W. Towler, M. Cruz, S. Do, J. E. Maher, K. Whitaker, M. Lerner, and K. A. Morton, GeroScience, 40, 49 (2018).

471. N. K. Khoo, N. Cantu-Medellin, J. E. Devlin, C. M. St Croix, S. C. Watkins, A. M. Fleming, H. C. Champion, R. P. Mason, B. A. Freeman, and E. E. Kelley, Free radical biology \& medicine, 52, 2312 (2012).

472. N. K. Khoo, N. Cantu-Medellin, C. S. Croix, and E. E. Kelley, Current Protocols in Cytometry (2015).

473. Q. Xin, Q. Liu, H. Shah, and J. R. Gong, The Analyst, 142, 316 (2017).

474. L. K. Bieniasz, Modelling Electroanalytical Experiments by the Integral Equation Method, Springer Berlin Heidelberg (2014). 